'This remarkable book, informed by unusually wide-ranging and sophisticated scholarship, is highly creative theoretically. Demertzis makes cultural trauma central to a political sociology of emotions, demonstrates how ressentiment illuminates populism and nationalism, and explains how forgiveness can be a key psychological-cum-moral action for rebuilding the fractured solidarities that threaten contemporary society.'

- Jeffrey C. Alexander, Lillian Chavenson Saden Professor of Sociology, Yale University, US

'In this work of wide-ranging and deep scholarship, Nicolas Demertzis provides a foundational text for the emergent field of the political sociology of the emotions. At the same time, in his rich analyses of the concepts of cultural trauma and ressentiment, and in their application to Greece, he draws not only on history but on philosophy and psychoanalysis, and shows how interdisciplinary work is central to the understanding of today's major issues. Anyone studying the emotional bases of politics will have much to learn from this book.'

- Barry Richards, Professor of Political Psychology, Bournemouth University, UK 


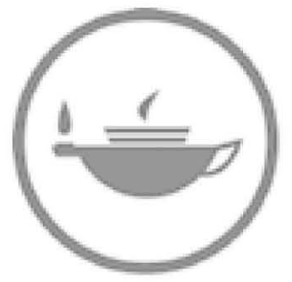

Taylor \& Francis Taylor \& Francis Group

http://taylorandfrancis.com 


\section{The Political Sociology of Emotions}

The Political Sociology of Emotions articulates the political sociology of emotions as a sub-field of emotions sociology in relation to cognate disciplines and sub-disciplines.

Far from reducing politics to affectivity, the political sociology of emotions is coterminous with political sociology itself plus the emotive angle added in the investigation of its traditional and more recent areas of research. The worldwide predominance of affective anti-politics (e.g., the securitization of immigration policies, reactionism, terrorism, competitive authoritarianism, nationalism and populism, etc.) makes the political sociology of emotions increasingly necessary in making the prospects of democracy and republicanism in the twenty-first century more intelligible.

Through a weak constructionist theoretical perspective, the book shows the utility of this new sub-field by addressing two central themes: trauma and ressentiment. Trauma is considered as a key cultural-political phenomenon of our times, evoking both negative and positive emotions; ressentiment is a pertaining individual and collective political emotion allied to insecurities and moral injuries. In tandem, they constitute fundamental experiences of late modern times. The value of the political sociology of emotions is revealed in the analysis of civil wars, cultural traumas, the politics of pity, the suffering of distant others in the media, populism, and national identities on both sides of the Atlantic.

Nicolas Demertzis is Professor at the National and Kapodistrian University of Athens and Director of the National Centre for Social Research (EKKE). His research focuses on political sociology, cultural sociology, political communication, and emotions sociology. He edited Emotions in Politics. The Affect Dimension in Political Tension (2013). 


\section{Routledge Studies in the Sociology of Emotions}

Mary Holmes Professor at the University of Edinburgh, UK and

Julie Brownlie Senior Lecturer at the University of Edinburgh, UK

The sociology of emotions has demonstrated the fundamental and pervasive relevance of emotions to all aspects of social life. It is not merely another specialized sub-discipline; rather it aims to reconfigure bases of mainstream sociology. This book series will not only be of interest for specialists in emotions but to sociology at large. It is a locus for developing enhanced understandings of core problems of sociology, such as power and politics, social interactions and everyday life, macromicro binaries, social institutions, gender regimes, global social transformations, the state, inequality and social exclusion, identities, bodies and much more.

\section{Emotions in Late Modernity}

Edited by Roger Patulny, Alberto Bellochi, Sukhmani Khorana, Rebecca Olson, Jordan McKenzie and Michelle Peterie

\section{Love as a Collective Action}

Latin America, Emotions and Interstitial Practices

Adrian Scribano

\section{Interactional Justice}

The Role of Emotions in the Performance of Loyalty

Lisa Flower

\section{Governing Affects}

Neo-Liberalism, Neo-Bureaucracies, and Service Work

Otto Penz and Birgit Sauer

\section{The Political Sociology of Emotions}

Essays on Trauma and Ressentiment

Nicolas Demertzis

For more information about this series, please visit: www.routledge.com/ sociology/series/RSSE 


\title{
The Political Sociology of Emotions
}

Essays on Trauma and Ressentiment

Nicolas Demertzis

\author{
Routledge \\ 侖 Taylor \& Francis Group


First published 2020

by Routledge

2 Park Square, Milton Park, Abingdon, Oxon OXI4 4RN

and by Routledge

52 Vanderbilt Avenue, New York, NY 10017

Routledge is an imprint of the Taylor \& Francis Group, an informa business

(C) 2020 Nicolas Demertzis

The right of Nicolas Demertzis to be identified as author of this work has been asserted by him in accordance with sections 77 and 78 of the Copyright, Designs and Patents Act 1988.

All rights reserved. No part of this book may be reprinted or reproduced or utilized in any form or by any electronic, mechanical, or other means, now known or hereafter invented, including photocopying and recording, or in any information storage or retrieval system, without permission in writing from the publishers.

Trademark notice: Product or corporate names may be trademarks or registered trademarks, and are used only for identification and explanation without intent to infringe.

British Library Cataloguing-in-Publication Data

A catalogue record for this book is available from the British Library

Library of Congress Cataloging-in-Publication Data

Names: Demertzis, Nikos, author.

Title: The political sociology of emotions : essays on trauma and ressentiment / Nicolas Demertzis.

Description: Milton Park, Abingdon, Oxon ; New York, NY : Routledge, 2020.

Series: Routledge studies in the sociology of emotions | Includes bibliographical references and index.

Identifiers: LCCN 2020008354 (print) | LCCN 2020008355 (ebook) |

ISBN 97808 I 5380733 (hardback) | ISBN 978I35 I 2 I 2472 (ebook)

Subjects: LCSH: Political sociology. | Emotions-Political aspects.

Classification: LCC JA76 .D365 2020 (print) | LCC JA76 (ebook) |

DDC 306.2-dc23

LC record available at https://lccn.loc.gov/2020008354

LC ebook record available at https://lccn.loc.gov/2020008355

ISBN: 978-0-8I53-8073-3 (hbk)

ISBN: 978-I-35I 2-I247-2 (ebk)

Typeset in Times New Roman

by Wearset Ltd, Boldon, Tyne and Wear 
To my family and friends.

The stepping-stones of a life cycle. 


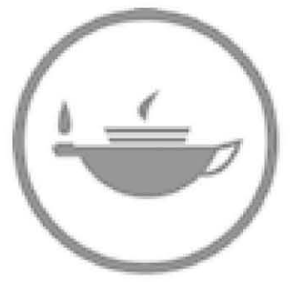

Taylor \& Francis Taylor \& Francis Group

http://taylorandfrancis.com 


\section{Contents}

Preface

1 The political sociology of emotions: an outline

Political sociology in search of emotionality 1

The sociology of emotions at a crossroads 5

Toward a political sociology of emotions 7

Synopsis 22

\section{PART I}

The politics of trauma

2 On trauma and cultural trauma

The semantic field and the historical-societal context 27

The cultural trauma theory 31

Normative and conceptual prospects of cultural trauma. A very short note 40

Synopsis 43

3 The civil war(s) trauma

Introduction 45

The event: historical context and prime political cultural consequences 46

The civil war as a collective injury 51

Designating the war 54

From collective injury to cultural trauma 56

Meta-theoretical repercussions 67

Synopsis 69 
4 Mediatizing traumatic experience and the emotions

Introduction 72

Emotions and the media 73

Media, trauma, and morality 77

Trends of the media-moral emotions nexus 86

Synopsis 87

5 Trauma and the politics of forgiveness

Entering the past 90

Reactions to traumas 91

Moral acumen in forgiveness 106

Synopsis 108

\section{PART II}

The politics of ressentiment

6 On resentment, ressentiment, and political action

Introducing the twin emotional terms 113

Of resentment 114

Of ressentiment 120

Towards an appraisal 132

Political bearings 140

Synopsis 144

7 Populism and the emotions

Introduction 150

Defining populism 151

Emotionally analyzing populism 152

Populism: an emotionally charged phenomenon 154

The case of Greek populism 159

Perspectives for further research 167

Synopsis 168

8 The emotionality of the nation-state

Introduction 170

The emotionally laden thought of nationalists 170

The emotions-driven studies of nationalism 172

Nation-state: emotionally driven nation-ness - nationally laden emotionality 177 
Beyond 'national sentiment' 179

The potency of ressentiment 183

Synopsis 197

Postscript

References

Index 


\section{Preface}

This book can be considered as a piece of work following the end of the 'emotions-proof' period in sociology. Its aim is two-fold: first, by putting together previously scattered initiatives and sociological research agendas related to the emotion-politics nexus, the book delineates the emerging political sociology of emotion as a sub-field of the sociology of emotions. Second, it focuses on some key political emotions and emotions-driven experiences such as trauma, national identity, forgiveness, populism, and the mediatization of emotionality.

The book consolidates my previous body of theoretical and empirical research over different themes and topics which have been re-elaborated and articulated in a systematic and more thorough manner. In addition, it includes new material drawn from secondary and primary quantitative and qualitative research on various drama trauma cases, the mediatization of emotions, resentment and ressentiment, and the traumatic experience of the Greek civil war. Examples from more than one national context will be referred to with Greece being of special interest because this country has recently gained undivided attention from the media and political analysts alike due to the repercussions of the sovereign debt crisis and the impact of neo-liberal fiscal policies on citizens' value priorities and processes of collective remembering. In addition, Greece's populist and nationalist politics offer the right playground for reviewing the politics-emotion nexus.

The book is organized around two central themes: trauma and ressentiment. They both constitute fundamental experiences of late modern times. Trauma is considered as a key cultural-political phenomenon of our times evoking both negative and positive emotions, and ressentiment as a key individual and collective political emotion allied to traumas and insecurities. More analytically, the discourse of progress and development has been more or less replaced by the discourse of crisis, and 'trauma' tends to develop into one of the master signifiers of late modern societies. It is not accidental that scholars talk about our times and culture as 'trauma time' and 'the culture of trauma'. Moreover, the sub-fields of memory studies, trauma studies and disaster studies have appeared in social science and humanities in tandem with the sociology of emotions. Issues related to trauma will be theoretically approached according to the tenets of the Yale cultural trauma middle-range theory. 
Interwoven with identity formation and reformation and stocks of social memory, traumatic experiences elicit negative and positive emotions and sentiments. Traumas break and remake social bonds and, in that sense, they evoke, inter alia, hatred, anger, fear, sorrow, resentment or ressentiment, on the one hand, and solidarity, dignity, compassion, and sympathy, on the other. As such, trauma and resentment/ressentiment should be considered alongside each other. Notwithstanding the confusion between resentment and ressentiment in contemporary political analysis and International Relations theory, the latter has come to be seen as a global negative emotion that permeates neo-liberal societies in at least two aspects: first, it is a compensatory emotional stance vis-à-vis failures faced by members of lower classes; second, it is thought of as an emotional motivation for Islamic terrorism.

The book makes a strong case for the establishment of political sociology of emotions as a sub-field of the parenting field of the sociology of emotions. The need for a political sociology of emotions stems from two factors: first, although emotions and affectivity were banned from mainstream political analysis ever since the late $50 \mathrm{~s}$, a good deal of political sociological research on political culture and the 'social bases of politics' has engulfed emotions already in its conceptual repertory. In the meantime, the emotionalization of social theory and the so-called 'affective turn' in social sciences and humanities cannot but affect political sociology itself which has also been constantly expanding its scope of interests. In this respect, the political sociology of emotions is not epistemologically different from late modern political sociology; it could not possibly break away from the general field of political sociology. On the contrary, the political sociology of emotions should be coterminous with political sociology plus the emotional 'filter' through which it attempts to causally explain and interpretatively understand its subject matters.

Second, the political sociology of emotions comes as a 'remedial' gesture to the excessive success of the sociology of emotions (or emotions sociology). Over the last ten years or so the divergence and the number of themes and topics the sociologists of emotions are coping with has become so great that this really dynamic field would be better off if 'formatted' in conjunction with particular though interlinked - spheres of social action and socio-analytic interest like economy and finance, academia, culture, politics, globalization, social philosophy, etc. In this sense, the political sociology of emotions is expected to contribute to the improvement of the academic division of labor within the sociology of emotions, in its way to become a 'normal paradigm'. Of course, there are certain contiguities between the political sociology of emotions and other sectors within emotions sociology, on the one hand, and cognate fields and disciplines like - among others - political psychology, cultural studies, and ethnography, on the other. This poses the double challenge of inter-sectional thematizations and delicate disciplinary boundaries to be addressed by this book as well as by other, and perhaps younger, colleagues willing to come to terms with this emergent sub-field. 
This book is a benchmark of a study program on emotion carried out over the last 15 years from a primarily sociological and, to a lesser degree, from a psychological and/or psychoanalytic and philosophical perspective being implicitly in a 'dialogue' with my much earlier - but never abandoned - preoccupations with political sociology and political communication. The central theoretical approach of this book is weak social constructionism as it attempts to bridge subjectivism and objectivism in understanding the ways social agents, being both rational and emotional, are carrying out their political projects in concrete historical conjunctures and space dimensions not fully acknowledging the prerequisites and consequences of their own action. In this sense, weak construction is kin to Giddens' structuration theory. Phenomenological method and historical-comparison are the main methods employed in the analyses of the subsequent chapters. A few words are needed herein: to really comprehend the situated experiences of resentment and ressentiment, requires the phenomenological attitude of epoché, namely, the suspending or bracketing of the researcher's prior knowledge of the phenomenon at hand and immersion into the subjects' experience as a disinterested sociological observer (Schutz 1978; Husserl 1978; Natanson 1978). In this way one transcends both the pure conceptual analysis of, let's say, resentment and ressentiment, and the ordinary givenness of their manifestations naively lived, as it were, by people under populist or nationalist political cultural settings. This is done through the employment of the reconstructive process of 'double hermeneutic', the second order interpretation of an already interpreted set of significations and emotions constituting everyday actors' life-world (Giddens 1984: 284, 374). Phenomenologically 'speaking reality' in terms of double hermeneutic ends up in a sort of coconsciousness, a fusion of hermeneutic horizons which by-passes solipsism and objectivism as methods of investigation (Gadamer 1979). This fusion takes place in time-space settings which are not to be seen as straightforward occurrences or as determining externalities, but as historical facts endowed with a deep inner structure of meaning and feeling. Hence the postulate that emotions are historically constructed and expressed while mediating culture and body. To grasp the historicity of emotions, it is necessary to go beyond analysis of cultural artefacts and compare different historico-political cases and phenomena. In this respect, comparisons were made in order to clarify, among others, experiences of trauma, civil war emotionality, and the affectivity of national habitus by using material from auto-biographies, novels, and poems as indicatively meaningful sources for the documentation of the emotional underpinning of the political cultural phenomena discussed in the chapters to follow. This material was selectively drawn from influential authors' work which symbolically condenses collective experiences and shared emotions. Among these authors are Dostoyevsky and Elytis, a great Greek Nobel Laureate. Apart from this, with regards to the Greek civil war and its traumatic repercussions, research material was collected through qualitative interviews with informants who took part on both sides of that war. Lastly, the analysis of populism and ressentiment is indirectly supported by quantitative work (e.g., Capelos and Demertzis 2018; Capelos, Katsanidou and Demertzis 2017). 
Overall, half of the book chapters are more conceptually rather than research oriented.

The introductory first chapter delineates the theoretical and methodological tenets for launching the political sociology of emotions as a promising subfield within emotions sociology. Part I is about the politics of trauma, leveraged by chapters dedicated to the theory of cultural trauma (Chapter 2), the trauma drama of the Greek civil war (Chapter 3), the moral implications incurred by the mediatization of traumatic emotional experiences (Chapter 4), and forgiveness as a possible moral-emotional response to victimization (Chapter 5). The second part refers to the politics of ressentiment and contains a long analysis of the twin emotional terms of resentment/ressentiment and their relevance to political action (Chapter 6), an examination of the emotional underpinnings of populism (Chapter 7), and an investigation of the emotional bases of the nationstate (Chapter 8). The emotional analysis of populism and nation-ness are principally premised on the elaboration of ressentiment made in Chapter 6 . Finally, the Postscript wrap ups the book's argumentation and discusses the boundaries and the links between the political sociology of emotions and cognate disciplines and sub-disciplines. 


\section{Acknowledgments}

Although the author is ultimately responsible for the published end product, I have to seek comfort in the multiple ways dear friends and colleagues have contributed in the creation of this book. Either during the meetings and conferences held by the Sociology of Emotions Research Network of the European Sociological Association, or in academic symposia, conferences, and seminars hosted in British, Irish, German and Greek Universities and Research Centers, as well as during private conversations, I have benefited from discussing with them my ideas and tentative theoretical propositions. Some of them have also read earlier versions of some of the chapters, offering valuable suggestions and criticism. In this respect, I would like to express an intellectual debt of gratitude to Alex Afouxenidis, Jack Barbalet, Tereza Capelos, Sean Homer, Alexandros-Andreas Kyrtsis, Gerasimos Moschonas, Mikko Salmela, and Yannis Stavrakakis. I am thankful to my theoretical interlocutors, first and foremost my Doktorvater Ron Eyerman for his constant support, as well as to Jeffrey Alexander, Bettina Davou, Jonathan Heaney, Thanos Lipowatz, Ilias Katsoulis, Thomas Koniavitis, and Nicos Mouzelis. I am also grateful to Nicolas Christakis, Petros Gougoulakis, Socratis Koniordos, Stamatis Poulakidakos, Christian von Scheve, Katarina Scherke, Eva Tomara, Charalambos Tsekeris, Panagiotis Vassiliou and Phaidon Vassiliou for their prompt bibliographical help. I also want to thank Mary Holmes and Julie Brownlie for encouraging me to go on with the book and hosting it in the Routledge Studies in the Sociology of Emotions.

In various places in the book, I have drawn on material from previously published work of mine: 'The Drama of the Greek Civil War Trauma', in R. Eyerman, J. C. Alexander, and E. Breese (Eds) Narrating Trauma. On the Impact of Collective Suffering. Colorado: Paradigm Publishers, 2013: 133-162; 'Mediatizing Traumas in the Risk Society. A sociology of emotions approach', in D. Hopkins, J. Kleres, H. Flam, and H. Kuzmics (Eds) Theorizing Emotions. Sociological Explorations and Applications. Frankfurt/New York: Campus Verlag, 2009: 143-168; 'Forgiveness and Ressentiment in the Age of Traumas'. In the Oxford Research Encyclopedia on Politics (Demertzis, 2017). This material has been re-worked to fit the rationale of the chapters in support of my 
attempt to carve out the political sociology of emotions as a new sociological sub-field.

Nicolas Demertzis

Athens, February 2020 


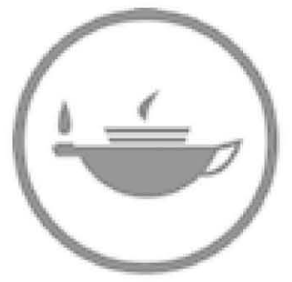

Taylor \& Francis Taylor \& Francis Group

http://taylorandfrancis.com 


\title{
The political sociology of emotions
}

\author{
An outline
}

\section{Political sociology in search of emotionality}

The term 'political sociology of emotions' or 'political sociology of emotion' is only rarely mentioned in academic literature (Berezin 2002; Demertzis 2006, 2013; Heaney 2019). If not used as a figure of speech, it alludes to the fact that it is possible to carve out a sub-field within the sociology of emotions. The question, however, is whether such a sub-field is really needed for doing better sociological work and more adequately analyzing the emotions-politics nexus or is destined to end up as another epistemic fractal which does no more than contribute to the disciplinary chaos (Abbott 2001) and the crisis of international sociology. This book argues for a genuine need for the creation of a political sociology of emotions and it is my conviction that there are two converging vectors pointing in this direction. The first refers to the evolution of political sociology itself; the other vector is the status of the sociology of emotions.

In one way or another, the relationship between social institutions and politics, policy, and polities has been an issue of concern for the nineteenth century social theorists premised on the relative separation of state, society, and economy, signaled by the advent of modernity. In brief, Karl Marx's political writings, which stand at odds with the once prominent historical materialist credos, as well as Max Weber's types of power and the theory of politics as vocation, shaped the space for political sociology to appear. The same holds of course for Alexis de Tocqueville's analysis of American democracy, Lorenz von Stein's study of the French Revolution, Robert Michels and Mosei Ostrogorski's pioneering studies on political parties, movements and bureaucracy, Vilfredo Pareto's sociology of political elites, and Georg Simmel's theoretical propositions on conflict, group affiliation and mobilization premised on emotional arousal (Turner 1975). Just before World War I, André Siegfried's electoral geography in France, and soon after World War II the electoral behavior studies at Columbia University (Paul Lazarsfeld, Bernard Berelson and Hazel Gaudet), made headway in producing a fully-fledged political sociology. The 1950s and early 1960s were actually the era of the emergence of political sociology as a separate and institutionalized field of theory and research. 
Next to the Columbia School of electoral studies, the influential group of the Michigan School (Angus Campbell, Gerald Gurin and Warren Miller) pushed the politico-psychological and socio-psychological study of voting preferences in the USA further. Due to the Cold-War political climate at the turn of the 1950s on the one hand and, on the other hand, the western concern for the cultural prerequisites of democracy in the Third World (as it was then called) and its legitimate consolidation in affluent countries in the 1960s, William Kornhauser's The Politics of Mass Society, Gabriel Almond and Sidney Verba's The Civic Culture, and Gabriel Almond and Bingham Powell's Comparative Politics edited in 1959, 1963, and 1966 respectively, were some strong forerunners for the establishment of political sociology.

Disciplinary-wise, however, the decisive milestones were Seymour Lipset's The Social Bases of Politics (1960) and Seymour Lipset and Stein Rokkan's Party Systems and Voter Alignments: Cross-national Perspectives (1967). As a product of the efforts made by the Committee of Political Sociology, founded at the 4th World Congress of the International Sociological Association in 1959, each book has been a landmark in the relevant literature. Since then, political sociology has ceased to be an underrated area of sociological investigation (Allardt 2001: 11704).

Inspired by Aristotle, Lipset's central concern was the conflict vs consensus dilemma permeating modern democratic politics. In this respect, acknowledging the intellectual debt to Marx, Tocqueville, Weber and Michels, and focusing mainly on the USA realities he established political sociology along four main tenets: the preconditions of democracy; voting as democratic class struggle; the sources of political behavior and the social bases of party support; the input of trade unions in political life. Even after the pathbreaking Party Systems and Voter Alignments, political sociology strove to defend itself as an autonomous and genuine field of its own, not to be seen as an intellectual transit station through which new(ish) issues and perspectives travel before being absorbed by the two 'parent' disciplines, i.e., sociology and political science (Nash and Scott 2001: 1).

There has been therefore a matter of disciplinary boundary which became all the more obvious in the early 1980s when political sociology engulfed poststructuralist, feminist and cultural studies perspectives. This happened because the main focus of political sociology ceased to be the social-class bases of the nation-state political power and its central institutions, namely, parties, elites and trade unions (Bottomore 1979). Sharply differentiated from the rational choice paradigm, the 'new political sociology' of the 1980s enlarged its scope far beyond formal politics to include a capillary re-conceptualization of power alongside the Foucauldian post-structuralist tenets. It was also influenced by the 'cultural turn' in sociology (Alexander and Smith 1998) placing emphasis thereafter on the meaning-making endeavors of political subjects as they are affected by postmodernization processes such as individualization, life-politics, post-materialism, informationalization, cognitive mobilization, etc. (Nash 2000: x-xiii). The 'cultural turn' in political sociology resulted in an increasing trend towards 
anti-essentialism and the rejection of grand narratives that emphasized the decentered nature of power and political mobilizations and the emotional repertories of political actors (Taylor 2010: 18-21, 85-90, 110, 196). In other words, in a global world of incremental complexity political sociology after the 1980 s conceptualizes, and to a certain extent contributes to, the enlargement of the boundaries of the political (Gransow and Offe 1982; Offe 1985). That is why identity politics, contentious politics and social movements action, gentrification processes, the mediatization of politics, and citizenship rights center-staged the political sociology agendas in the USA and Europe.

No doubt, one of the most crucial factors that drove this re-direction comprises the intensified processes of globalization and/or glocalization ever since the 1990s; as a consequence, political sociology has been all the more disjoined from methodological nationalism which was anyway about to lose its grip by the ' 60 s because of the rapid development of comparative politics. This has not only been inscribed in the widening of its thematic agendas, including thereafter transnational social and political movements, digital politics, and multinational corporate business next to more traditional topics such as political participation, power and authority, political parties and civil society (Orum and Dale 2009). ${ }^{1}$ It is also expressed via the emergence of International Political Sociology, a combination of political sociology and international relations to be studied through con-current empirical and theoretical analysis and research of transversal issues and topics. Thus, global governance, international citizenship, political geographies, and big data surveillance are, among others, the prime object of attention studied from a more or less processual and relational perspective (Basaran et al. 2017), much owed to Emmanuel Wallerstein's world-systems theory and his conceptualizations of geopolitics and geo-culture, as well as of the anti-systemic social movements (Wallerstein 2000; Mateos and Laiz 2018).

Apparently, the proliferation of themes and perspectives conferred added value to political sociology which in the meantime had become a highly established section within sociology even if it lacks disciplinary rigidity (Hicks et al. 2005). Thematic, theoretical and methodological fluidity, disciplinary contiguity and interconnectivity have been called forth by the extant de-differentiation of the scientific serendipity employed in our post-modern era (Crook et al. 1992: 197-219). Notwithstanding cross-fertilization and multifaceted analyses, it seems that since the 1980 s political sociologists have not let themselves open to the insights of, nor did they valorize the conceptualizations drawn from, the fast-growing sociology of emotions. Even if a good number of them have been affected by the cultural turn of the ' 80 s in the first place, they have not systematically incorporated the affective dimension in the analysis of political phenomena. Indicatively, in the highly inclusive Handbook of Janoski et al. (2005) only two chapters (out of 32) adequately address emotionality with respect to the interpretation of the politics of culture, protest movements and revolutions. Yet, the authors, James Jasper and Jeff Goodwin, were already established sociologists of emotions and social movements (Jasper 2005; Goodwin 2005) who promulgated 
the need for political sociologists to embrace cultural and emotional concepts in their theoretical toolkit.

More recently, in The SAGE Handbook of Political Sociology, a two-volume and 67 chapter piece of comprehensive work (Outhwaite and Turner 2018), there is hardly any substantive reference to the sociology of emotions, or to emotion or affect, or to particular emotional terms such as fear, anger, resentment, shame, and hatred, especially in the analysis of hot topics like violence, movements, revolutions, and war where such a reference would reasonably be expected. It seems that when emotions meet politics in scientific investigation there is still suspicion or even negligence of their importance and they continue to be treated as something 'other' to mainstream analyses (Heaney 2019).

At any rate, treating emotionality as a side issue runs counter to the number of contributions in which emotions were a part of the analysis both before and after the formal disciplinary setting of political sociology where emotions were already brought into the analysis. Although Marx is considered among the forerunners of political sociology, his assertion while criticizing Hegel's philosophy of right that, for the identification of the particular interest of a class with the interest of society as a whole there has to be 'a moment of enthusiasm' (Marx 1844/1978: 27-28) usually passes unnoticed. In equal measure, although Antonio Gramsci's notion of hegemony is frequently referred to, scholars seem to overstress its moral-intellectual aspect while overlooking the necessity of "organized political passion" which prompts the overcoming of individual calculations in an "incandescent atmosphere" of emotions and desires (Gramsci 1971: 138-140). Against the rationalist understanding of politics, even more explicit is the inclusion of emotionality in the theory of political culture proposed by Almond and Verba (1963) who say that, alongside cognitive and evaluative orientations, a political culture is also composed of affective orientations towards such political objects as the structures of inputs and outputs, and the self as political agent. The same holds true for the Michigan School's pivotal notion of party identification as the main driver of voting preference, ${ }^{2}$ as well as for the widespread academic interest in trust as supportive and cynicism as undermining elements of democracy (Cappella and Jamieson 1997; Warren 1999). However, political sociologists were not prepared to push the point further and systematically cope with the politics-emotion nexus. Accordingly, they paid, as it were, more attention to Giddens's 'Third Road' than to the possibility of a 'democracy of emotions' which can be cultivated reflexively in intimate relationships in order to reinforce at a later stage the 'life politics' of social groups struggling for alternative expression beyond the traditional publicprivate distinction (Giddens 1992: 184, 1994: 16, 119-121).

Fifteen years ago, commenting on its future, Hicks et al. (2005: 4) maintained that despite its success in focusing on the social bases of politics, political sociology 'needs to be more inclusive of recent developments' and undertake possible syntheses of new developments into existing theories. Today we may claim that this need has been partially met; if anything, and even if one sticks to its hard core, i.e., political power, one would expect that the emotional element could be 
given more chances by political sociologists, to the extent that it is also through emotions that in every society the mode of political domination is reproduced and ideologically justified. Or, as recently argued, to the extent politics is about the creation, maintenance and use of power, political actors understand the relevance of the creation of relatively stable affective dynamics to further political projects, both as a target for destabilization when it comes to their political opponents, and as a goal to achieve for themselves (Slaby and Bens 2019: 345-346). The point therefore is to complement the study of the social bases of politics with an analysis of its emotional bases which, nevertheless, have been initially explored ever since the late 1970 s by sociologists of emotions like Theodore Kemper, Randall Collins, Arlie Hochschild, David Heise, Susan Shott, etc. As it is rightly put, 'a research agenda for a renewed and revitalized political sociology needs to focus on the ways in which people "feel", "experience" and "live" the complex contradictions of the social and political world' (Taylor 2010: 198).

\section{The sociology of emotions at a crossroads}

In both sides of the Atlantic, the sociology of emotions has now come of age and the fast-growing research on political neuroscience, affective political psychology, and affective science for that matter, have rendered the demarcation between emotion and reason in analysing politics a thing of the past. As a field, the sociology of emotions has been growing in a steadfast way and since the early ' 80 s, it has been developing into a 'normal' but no less multifaceted, if not amorphous, scientific paradigm. ${ }^{3}$ As a consequence, a very large number of social scientists worldwide have come to realize that any description, explanation or interpretation of social phenomena is incomplete, or even false, if it does not incorporate the feeling and embodied subject into their study of structures and social processes (Bericat 2016). This is an achievement of the sociology of emotions.

Notwithstanding pertinent definitional matters, i.e., how to conceptualize emotional terms like affect, sentiment, passion, feeling, emotion, mood etc. (Demertzis 2013: 4-6; Slaby and von Scheve 2019b), the sociology of emotions has made us social scientists become fully aware of at least two aspects of the human condition. First, emotions are culturally mediated; namely, any sort of emotions, be it moral, primary, secondary, programmatic, anticipating etc. is: (a) elicited and experienced relationally and situationally, (b) expressed according to social conventions (feeling rules) and structures of feeling which make for its valence, arousal, and potency, (c) discursively narrated within and through language games partaking thus in identity and will formation processes. Second, any socio-political phenomenon is permeated by emotionality which means that, in different degrees, social agents are always both rational actors and sentimental citizens. In this respect, the sociology of emotions contributes to the general sociological theorizations by systematically providing an emotions-centered lens on the world and on social order (Hochschild 2009; von Scheve 2013). 
When the pioneers of the field (Hochschild, Scheff, Kemper, Collins) coined the term in the early and mid-1970s, they probably could not foresee the steadfast pace with which the sociology of emotions would move forward over the next few decades. Suffice it to mention that in 1975 Thomas Scheff in San Francisco organized within the American Sociological Association (ASA) the first session ever on emotions. ${ }^{4}$ The very same year Randall Collins published his Conflict Sociology wherein emotions are given a central explanatory role for the emergence and the resolution of conflicts and the micro-dynamics of social stratification and, while reflecting on the relationship between emotion and gender, Arlie Hochschild was the first to use the term 'sociology of emotions' (Hochschild 1975). Four years later she published a highly promising article on the sociological analysis of emotions which finally led to her classic The Managed Heart in 1983. Those works resonated with the American and European Zeitgeist of the 1960s where expressivity and the self were center-staged (Kemper 1991: 303).

Given that strong interest, in 1986 the ASA formally established a standing section on the sociology of emotions and the following year in Chicago it organized two thematic sessions which resulted in the Research Agendas in the Sociology of Emotions edited by Kemper (1990). Prompted by the emotional turn in social sciences and humanities, in 1990 the British Sociological Association set up a study group for the sociological investigation of emotions and in the 1992 annual meeting of the Australian Sociological Association, a session on the sociology of emotions was organized for the first time. Also, in 2004 a Research Network for the sociology of emotions was formed in the European Sociological Association, and has expanded significantly in terms of membership and activities (Kleres 2009). Network members have been instrumental in launching a new book series on emotions (Routledge Studies in the Sociology of Emotions) and the new sociological journal Emotions \& Society.

Apart from different theoretical perspectives (e.g., constructionism, structural theories, etc.), a glance at the conference programs of the European Sociological Association Research Network of the Sociology of Emotions ${ }^{5}$ over the last ten years or so is indicative enough for someone to realize that this field has been developing in many directions: economics and finance, politics and civic action, law and justice, counseling, international relations, media of communication, gender relations and identities, organization, intimate relations and personal life, migration, globalization, post-conflict societies, language and literature, history, body and sexualities, social geography, religion, morality and philosophy. Such a variety is the unavoidable and, to a certain extent, welcome consequence of the fervent emotional/affective turn in sociology (Clough and Halley 2007; Hopkins et al. 2009). One wonders, however, if this 'let a hundred flowers bloom' sort of development will go on forever, thus compelling the sociology of emotions to become coterminous with sociology itself.

In view of such a rather bizarre prospect, the sociology of emotions needs to be somewhat formatted. This can be done by clustering emotionality around central spheres of social action such as economy, culture, politics, religion, and so on. 
As a relatively separate field, then, the political sociology of emotions comes forth as a remedial response to the overexpansion of its disciplinary matrix.

\section{Toward a political sociology of emotions}

Given the growth in the sociology of emotions as a generic field of study, a robust political sociology of emotions has not yet been established although academics have come to realize both the importance of affect and emotions as a micro-foundation of political action and macropolitical institutionalization, and the necessity of studying the politics-emotion nexus in a rigorous way. In Bourdieusean terminology, the political sociology of emotions is needed for the comprehension of the emotionality ingrained into the political field and the ways politicians' emotional capital is converted into political capital, with 'emotional capital' understood herein as the 'embodied' part of cultural capital (Heaney 2019). At any rate, however, just as the field of sociology of emotions existed for a long time without the name, as rightly argued by Hochschild (2009: 29), the same is true for the political sociology of emotions. A good number of scholars have already carved out the space for its emergence as a distinct sub-field wherein their work may be embedded retroactively. Their work is found in influential edited volumes or published as articles in refereed journals. The space here does not permit exhaustive or detailed treatment. It suffices, however, to selectively brief on some areas of research which have made an impelling contribution toward a would-be political sociology of emotions.

After many years of under-evaluation, bringing emotions back in the analysis of social movements was characterized as the 'return of the repressed'. Movement analysis could not remain unaffected by the affective turn and, from the late 1990s on, a growing number of related works have reset the agenda in movement research. It has been postulated that if political opportunities delineate the condition of the possible for the genesis of a movement, people will not be able to participate in it without feelings of solidarity, loyalty, efficacy, anger, hope, frustration, vengeance, enthusiasm, or devotion (Benski and Langman 2013). The analysis of emotions has contributed to the systematic understanding of the emergence, duration, action, decline and effectiveness of social movements. This is the direction taken, among others, by Goodwin et al. (2001a, 2004), Flam and King (2005), Goodwin and Jasper (2006), Van Stekelenburg and Klandermans (2011) and Van Troost, Van Stekelenburg, and Klandermans (2013). In effect, these works have been focusing on two planes: (a) since 'every cognitive frame implies emotional framing' (Flam 2005: 24), scholars have been preoccupied with the re-framing of emotional reality as part of movements' strategic planning; (b) they scrutinized the emotional energy created in the internal dynamics of a movement.

Apart from the socio-political movements' analysis, the multi-layered emotions-politics nexus was discussed in an edited volume based on papers presented at a conference held at Bristol in 2004 (Clarke, Hoggett, and Thompson 2006). 
Most of the chapters are influenced by psychoanalytic approaches to specific emotions like envy, ressentiment, hatred, pity, compassion, etc. These emotions were linked to political phenomena such as populism, justice, voting, and mobilizations while most of the chapter authors (Jack Barbalet, James Jasper, Nicolas Demertzis, Paul Hoggett) addressed the emotionality-rationality dichotomy. Two of the editors reappeared six years later with another collective volume which further expanded the scope of their discussion. Most of the chapters point to the crucial role of specific emotions like fear, forgiveness, love, despair and enthusiasm in national and international affairs (Thompson and Hoggett 2012).

Bearing in mind that the thematic hardcore of traditional political sociology is the causal explanation and interpretive understanding of the societal processes behind the distribution, legitimation, and the exercise of political power, the special issue on emotions and power edited by Jonathan Heaney in the Journal of Political Power (2013) comes as no surprise. Two years later, Heaney and Flam (2015) turned it into a book, the chapters of which (re)connect power and emotion as two fundamental constituents of the human condition which, as argued, until recently have been studied in parallel. The contributors accomplish this on a diverse array of topics such as education, organizations, social movements, politics, the media, rhetoric, and comparative intellectual history.

Precisely because global risks and insecurities are permeating contemporary societies, fear and anxiety have been scrutinized with respect to their origins, uses and consequences. Relevant pointers can be found in historic approaches to fear in different political-cultural settings (Burke 2005), socio-psychological research on objectless and free-floating emotional climates of fear (de Rivera 1992), and in the post-modern 'liquid fear' and anxiety as a kind of derivative or seconddegree fear which is deemed a steady frame of mind that, even in the absence of an imminent and tangible threat, instils systematically a sense of insecurity and vulnerability (Bauman 2006: 3-4, 132; Glassner 1999). They can also be found in many approaches of 'political fear' and/or the 'politics of fear' and the securitization of migration flows (Robin 2004; Barbalet and Demertzis 2013; Kinnvall and Nesbitt-Larking 2011) where, among others, fear is seen as a political tool of the power elite rule as well as of subordinated groups who can occasionally jeopardize the elite's privileges.

In her insightful argumentation, Sara Ahmed (2004) foretells issues and topics for a future political sociology. Based on a relational approach, in what she calls 'the sociality of emotion', she combines psychoanalytic, post-colonial and critical feminist theoretical postures in an attempt to answer the question 'why are relations of power so intractable and enduring, even in the face of collective forms of resistance?' (Ahmed 2004: 12). In this attempt, among others she scrutinizes pain, hatred, fear, disgust, shame, and love in relation to violence, national identities, heteronormativity, and trauma.

Two other research areas of equal importance anticipating, as it were, the political sociology of emotions, are the media of communication and the public sphere. Including emotions in media studies is nothing new; ever since propaganda 
research and media violence research in the first quarter of the twentieth century emotional appeals and interpellations have been in many ways a central theme of analysis. Yet, the more recent emotional turn in social sciences ensued even more academic thrust; it has been understood, for example, that the media, old and new alike, contribute to the sharing of emotions, the forging of intimacy relations at a distance (Thompson 1995), and the construction of public emotional agendas (Döveling 2009). It has also been realized that media usage is not only a means but also a cause of affect and emotion regulation (Schramm and Wirth 2008). In addition, the place of emotion in journalism, either for gaining access to personalized authentic story-telling or when it comes to the hidden emotional labor performed by journalists themselves, has been highly estimated in our contemporary environment of mediatized politics, be it mainstream, populist, identity-centered, or post-identity politics (Wahl-Jorgensen 2019; Yates 2015). At any rate, a large block of evidence about the role of emotions in communications is found also in the new/social media studies (Papacharissi 2015; Benski and Fisher 2014) and, up to a certain point, it is systematically arranged in the Handbook of Emotions and Mass Media edited by Katrin Döveling, Christian von Scheve, and Elly A. Konijn (2011).

The more the publics become affective through Twitter and Facebook usage, the more emotionality is infused in the public sphere (Slaby and von Scheve 2019b: 21-22). Oscillating between being a forum of deliberation and serving as a space of cacophony, the national and international public sphere is multidimensional and ambivalent regarding political and social identity formation processes. This is not just the result of social media networking; it has deep roots in cognitive and emotional capitalism (Moulier-Boutang 2012) and the concomitant individualization coupled with the increased informalization of feeling rules in late modernity (Wouters 2007) and neo-liberal governmentality (Illouz 2007). It is by no means coincidental that the concept of the 'emotional public sphere', alongside the 'emotionalization of public life' and 'emotional governance' - and 'emotional resistance' for that matter - has come to the fore as a field intertwined with the traditional public sphere of rational debate and of formal democratic institutions and processes (Richards 2007). The emotional public sphere calls forth a distinction between democratic emotionality and demagogic emotional manipulation. Albeit not an easy distinction, it is of importance for the formation of not just responsive, but also responsible leaders and publics, who are to keep alive the tradition of res publica. For the point is not to efface or disavow emotionality from political culture and the public sphere. This would indeed be naïve and obsolete, an old-fashioned rationalistic regression; the point is to substantiate the so-called sentimental citizen and emotional reflexivity (Demertzis and Tsekeris 2018).

As already mentioned, not every research area deemed to foreshadow the political sociology of emotions can be described, let alone to be overhauled, in this section. In broad strokes, it can be said that a political sociology of emotions is premised on over-researched areas and that it is expected to gain saliency when 
less researched and researchable issues and topics will be dealt with in the oncoming years. That being said, two glaring questions are called forth, an epistemological and an epistemic one: (a) if it is high time to delineate a sociology of emotions, what is its epistemological status? and (b) what are its boundaries with other cognate fields and sub-disciplines?

First and foremost, we should take note of not conflating the political sociology of emotions with an emotive political sociology. The latter would reduce, in a monistic way, political phenomena to emotions and feelings, it would render them affective phenomena in toto. On the contrary, a political sociology of emotions would explicitly integrate the emotional/affective perspective in its conceptual toolkit and analytics. More to the point, any political sociology of emotions could not possibly break away from the 'parental' field of political sociology and, paradoxically, the political sociology of emotions should be in principle coterminous with political sociology which is, as we showed earlier, an ever-growing discipline in itself. It would ultimately be a mistake to construe the political sociology of emotions as emanating only from the dynamics of the 'social movements society' and the post-modern mediatization processes. Hitherto the emotionalization of science and society has been highly salient as the readdressing of core questions, themes and topics of political sociology such as the state, party competition, and political power becomes all the more necessary. As it is rightly put,

if the political sociology of emotion is to fulfil its potential, it will need to move beyond its current focus on movement and protest - on what might be considered "exceptional" politics, important as these are - to (re)address these core components of political life that were so central to the concerns of the founding fathers, including, and especially, the relationship between emotions and 'the state', political parties, and embodied politicians.

(Heaney 2019: 3)

In other words, the political sociology of emotions is none 'other' than its original scientific discipline (namely, political sociology). To illustrate the point further, epistemologically the political sociology of emotions is double-edged: affectively, it is a subfield of the sociology of emotions; politically, it is coterminous with political sociology in the making. It could be seen then as a theoretical hybrid; however, the political sociology of emotions is not to subvert or undermine the political sociology research agendas. Remaining analytically at the middle-range level of theorization, it just adds an emotional/affective filter through which political sociology(ies) approaches its objects. This is what I shall be doing in the following chapters.

The boundary-issue referred to above regarding political sociology is concomitantly, not to say inevitably, reappearing in the political sociology of emotions. It seems that the relationship/difference between political psychology(ies) ${ }^{6}$ and the political sociology of emotions, as far as the analysis of political behavior and the illumination of the emotion-politics nexus are concerned, is the most 
striking case in point. Over the last twenty years or so a tremendous amount of theoretical and empirical work has been conducted by American and European political psychologists and political neuroscientists focusing, among others, on party identification and identity politics, electoral preferences, political participation, opinion making processes, decision making, intergroup relations, and conflict analysis (e.g., Sears et al. 2003; Nesbitt-Larking et al. 2014). ${ }^{7}$ From an ideal type perspective, the political psychology of emotions points to a more individual-level analysis of opinionation, decision making, and electoral choice remaining for the most part at the micro-analytical level. In contrast, the political sociology of emotions perspective is expected to employ historical, cultural and socio-psychological conceptualizations and set its thematizations on a more or less macro level, paying attention to shared or collective vis-à-vis individual emotions, pondering over concepts like feeling rules, structures of feeling, emotional regimes, emotional cultures, emotional climates and emotional atmospheres.

Not infrequently, however, epistemic boundaries are transgressed and what actually counts is the degree of interdisciplinarity and crisscrossing thematizations in the analysis of the emotion-politics nexus. Insofar as emotions do not emanate within the individual as much as between the individuals and their social situations (Barbalet 1998: 67), or as long as they are not 'in' either the individual or the social, but are the interfaces for the very constitution of the psychic and the social as objects (Ahmed 2004: 10), the micro-macro dualism collapses as an epistemological, let alone ontological, postulate. It can remain only as a methodological distinction and as an analytic tool that helps us 'to view the same social processes or social practices both from the point of view of actors and from that of systems' (Mouzelis 2008: 226-227). Thus, the micro-macro distinction becomes one of scale and ratio (Ellis 1999: 34) and that is why social scientists have tried to connect them in multiple ways (Alexander and Giesen 1987: 14) or to bridge them by inserting the meso level of analysis (Girvin 1990: 34-36; Charalambis and Demertzis 1993; von Scheve and von Luede 2005; Turner and Stets 2005: 312-313). With regard to the analysis of emotions, the micro level concerns the intrapersonal dimensions of emotive life, and the meso level corresponds to social interaction in groups, institutions, everyday encounters and the emotional dynamic therein, whereas the macro level entails norms, rules, law, traditions and socio-economic structures which provide the path dependency for emotional cultures and social emotions to be formed. An attempt will be made to follow this line of methodological approach while analyzing topics and issues in the following chapters about populism, anti-politics, memorialization politics, and nationalism.

\section{The political sociology of emotions' raw material: political emotions}

In its attempt to dismantle the affective/emotional bases of politics, the political sociology of emotions is destined to always come across political emotions. 
Probably due to the sentimentalism of the rising 'Trumpism' and right-wing populism, this term has only recently gained currency academically or otherwise; on 10 January 2013 a Google search gave 18,900 results for 'political emotions', and just 8,470 for 'political emotion' (Demertzis 2014). On 15 February 2020 the figures totalled $160,000,000$ and $132,000,000$ respectively. In one way or another this term is employed as a means to designate the crucial role affectivity plays in politics.

As a theoretical notion, before its current popularity, political emotion had been used more often by political philosophers, not however without some vagueness and ambiguity. For instance, Barbara Koziak defines them circularly as the kind of emotions enacted in political processes (Koziak 2000: 29). In an implicit dialogue with John Rawls regarding the role of positive emotions like love and compassion for the promotion of a secular, just, and liberal society where everyone should enjoy the same rights that are granted to others, Martha Nussbaum does make use of the term 'political emotions' but she hardly gives a systematic definition or conceptualization of them (Nussbaum 2006, 2013). Scrutinizing Aristotle's theses on emotions, Marlene Sokolon describes them as those emotions that are relevant to a political community, fulfilling at least one of the following conditions: a) habituating into ethical dispositions, b) connecting to the question of justice, c) altering an individual's judgment (Sokolon 2006: 17).

Its usage by social scientists, political sociologists, and communication scholars spans from total un-theorization (e.g., Berezin 2001; Weber 2018; WahlJorgersen 2019: 34, 89, 129), ending up with conceptual refinement (e.g., Protevi 2014). At any rate, the concept stands unclear as it is frequently conflated with the cognate notion of 'political affect' (Protevi 2009; Gould 2010). Inspired by Spinoza's affection-affect interplay, as something which acts upon the body and as something which is acted upon by consciousness, the media philosopher Brian Massumi (2002), a founder of the 'cultural affect theory', refers to 'affect' as a pre-social, unnamed and never fully conscious nonlinear complexity, prior to passivity and activity. Seen in this light, Massumi's affect serves as a whole and overarching emotional climate which is linked metonymically to the particular emotions that may, as it were, spring from it. In his own words, emotion is 'a subjective content ... qualified intensity, the conventional, consensual point of insertion of intensity ... into narrativizable action-reaction circuits ... it is intensity owned and recognized' (Massumi 2002: 28).

In a similar vein, Deborah Gould, drawing on Massumi's work, makes a distinction between 'affect, as bodily sensation that exceeds what is actualized through language or gesture, and an emotion or emotions' (Gould 2010: 27). ${ }^{8}$ A cognate approach of political affect was adopted by John Protevi, a philosopher influenced by Gilles Deleuze; he conceptualizes political affect as a non-individualistic embodied affective cognition and as an 'imbrication' of the socio-political, the psychological, and the physiological (Protevi 2009). In concretising this highly abstract notion, he analyzes specific cases taken from American socio-political history (the Louisiana slave revolt, Hurricane Katrina, the Columbine High 
School shootings, etc.) where fear, rage, and love sit at the centre of what he calls body politic. Five years later he appears to have abandoned the 'political affect' designation; in a chapter on 'political emotion', he adopts a situationist and interpersonal processual approach to emotions 'encompassing brain, body, and world'. Upon this premise he defines political emotion as a collective emotion elicited within a political context by an event or an issue which is necessarily the focus of the emotional person (Protevi 2014: 327). To the extent that it is the relational-processual property of an emergent collective subject and not just the aggregate of individual affective reactions, a political emotion, precisely because of its political nature, sets three interlocking thymotic situational axes: the transversal between opposing groups, the horizontal within each competing group, and the adjunctive relation to bystanders (Protevi 2014: 328). Recently, Slaby and Bens (2019) proposed a generic philosophical, but no less amorphous, notion of political affect derived from the web of Spinoza's passive and active affects which eventually comprises the ontology of the Political.

Wrapping up the entire argument of the book, in the Postscript I will come back to the discussion of affect and emotion. For the time being it suffices to say that, due to its conceptual vagueness and visceral nature, affect matches conceptually better to cultural studies, ethnography and psychoanalytic sociology; instead, a componential concept of emotion, and political emotion for that matter, is compatible with the middle-range theoretical status of the sociology of emotions. In this respect, 'emotion' is a boundary marker between the political sociology of emotions and cognate disciplines and sub-disciplines. Keeping thus a distance from the cultural affect theory, my own definition goes as follows: political emotions are lasting affective predispositions supported reciprocally by the political and social norms of a given society, playing a key role in the constitution of its political culture and the authoritative allocation of resources (Demertzis 2014: 227-228). Accordingly, political emotions are:

a Inherently (but not exclusively) relational and social: they are elicited from asymmetrical figurations of power and are triggered by appraisals that make a reference to other people (Elster 1999: 139) or institutions engaging people: fear, hope, gratitude, anger, vengeance, disgust, awe, trust, distrust are only some of the extant affective reactions within a polity.

b Programmatic, in the sense that they are long-term affective commitments and dispositions toward political figures (for example adoration and devotion for a charismatic leader), political symbols, ideas or institutions (Sears 2001; Barbalet 2006). Take for instance patriotism and solidarity when it comes to the nation-state, and social movement activity which is also fuelled by resentment, hatred, displaced shame, and ressentiment. As lasting affective states, political emotions include what Goodwin et al. (2001b: 10-11) call 'moods', as well as what de Rivera (1992) calls 'emotional climate'. Moods or emotional climates are equally lasting and stable experiences that differ from (political) emotions in not having a definite object. 
c Not necessarily consciously felt; one may be thoroughly proud of one's country while at the same time hating unconsciously other nationalities. Or, as Scheff (1994b) has demonstrated, one's conscious anger against a political opponent may be symptomatic of suppressed shame. Although they speak of unconscious affective systems rather than distinct emotions, theorists of 'affective intelligence' have convincingly shown that much of political judgment and decision making is taking place below the threshold of awareness (Marcus et al. 2000).

d Self-targeted or introjected (e.g., shame, pride, fear, anxiety, sorrow) as much as they are other-targeted or extroverted (e.g., admiration, compassion, anger, hatred, generosity, loyalty).

e Individual as well as collective or shared.

f Oftentimes ambivalent, antithetical or incongruent; incongruent emotions are elicited when subjects experience simultaneously incompatible affective tendencies. Namely, people may experience intense fear, which normally leads to 'flight mode' behaviour, and at the same time anger, which activates aggressiveness. Class resentment may co-exist with degrees of admiration linked to emulating tendencies (Benski 2011; Benski and Langman 2013; Maldonado 2019: 20-21).

A strong case should be made at this point as to the fact that there are no prefixed and inherent political emotions. Any emotion whatsoever may acquire political character as long as it is involved in the political antagonism and insofar as political practices, public policy shaping and implementation, as well as polity institutional arrangements, are inexorably but not exclusively founded on emotional grounds (Revault d'Allonnes 2008). To put it differently, there are no exclusively political emotions but only 'scenarios' and modalities of political involvement and emotionality (Koziak 2000: 29) occurring in various figurations wherein any emotion may acquire political significance. Politicians and political parties valorise their emotional capital when they trigger and manage political emotions. Thus, political emotions are not a generically different kind of affective experience; they are emotions that play a crucial role in the formation of political reality.

If this is actually the case, disregarding short-term emotions altogether is erroneous. Apart from enduring programmatic (political) emotions or sentiments, short term reflex emotions play a considerable role too, especially in periods of political tension (demonstrations, riots, petitions, etc.) as well as in political information processing and impression management. The above-mentioned definition encompasses 'higher order' emotions or sentiments linked to central functions of a political system and the basic tenets of a political culture (or subculture). ${ }^{9}$ They may be designated as 'political emotions proper' or as 'salient political emotions' (Sokolon 2006: 181), differentiated from what I would call 'politically relevant emotions', i.e., urges, reflexes and highly transient affective experiences which in general play a marginal role in the longue durée of the Political. The political emotions proper are culturally-socially constructed and have a strong cognitive 
and moral component (Goodwin et al. 2001b: 13). In all likelihood the political sociology of emotions, as attempted in the following chapters, is bound to valorise the former type of political emotions more than the latter. In order to illustrate the above, the next section of this chapter focuses on (political) cynicism.

\section{Cynicism as political emotion}

Contemporary political systems are facing pertinent legitimation and rationality crises. This is often manifested in decreasing electoral turnout and volatile voting behavior, negativism and dissatisfaction with politics and political personnel, political apathy, civil disobedience, decreasing civic engagement or even incivisme, and decreasing party membership and partisanship, as well as pessimism regarding the future of western democratic polities (Dalton 1988: 225-244; Gibbins 1990). All these issues go along with a subjective sense of political inefficacy, alienation and cynicism, three interrelated aspects of contemporary political malaise. Usually, political cynicism is understood as disbelief in the sincerity, honesty or goodness of political authorities, political groups, political institutions or even the political system itself as a whole (Milbrath and Goel 1977; Listhaug 1995; Barnes, Kaase et al. 1979: 575). Also, it is conceived as a lack of civic duty, i.e., the obligation and responsibility to engage in public affairs (Woshinsky 1995: 118). For Cappella and Jamieson (1997: 19, 141-2, 166) the center of the concept of political cynicism is the absence of trust independently of evidence pro or con. In political life, the cynic, sealed within her/his own self-reinforcing assumptions, begins with mistrust and must be persuaded to the opposite view. As a kind of judgment, they define political cynicism as mistrust generalized from particular leaders or political groups to the political process as a whole - a process perceived to corrupt the persons who participate in it, and that draws corrupt persons as participants.

Keeping a distance from this conceptualization, I argue that political cynicism is more than a kind of political judgment and is not coeval to skepticism and distrust, either obsessive or paranoid. It is a very complex concept which brings into play a variety of cognitive and affective orientations towards politics. It is a cluster political emotion, one that is not easily operationalized in empirical political analysis. For one thing, the current discussion on political cynicism is rooted in the post-modern condition which leaves contemporary western societies appearing as 'post-ideological' and 'post-deontic' (Lipovetsky 1992). As the subjects in the West are experiencing the loss of a steadfast rational and - what is more - moral canon guiding their judgment (Bauman 1993: 9-10), the binding power of ideologies is shrinking (Žižek 1989: 7, 28-30). Since 'the grand narrative has lost its credibility' bringing on de-legitimation and radical suspicion towards 'preestablished rules' (Lyotard 1984: 37, 81; Rosenau 1992: 133-137), individuals become all the more aporetic and distrustful of the offered ideological truths. Thus, in the gradual absence of ethical restrictions (Baudrillard 1983), the moral situation of post-modernity is comprised of the standpoint that 'yesterday's 
idealists have become pragmatic' (Bauman 1993: 2) and that 'liars call liars liars' (Sloterdijk (1988: xxvii).

Further on, the post-ideological character of contemporary western societies lies exactly in that, despite all the distrust towards ideologies and 'great narratives', people continue to act as if they believed them. It is a sort of 'enlightened false consciousness', a contemporary version of the discontent in civilization described by Freud. It is a diffuse and almost all-embracing cynicism in an era when the distance and difference between progress and regression, rationalism and irrationalism, Right and Left have been suppressed in social consciousness, therefore losing much of their past social and political validity (Žižek 1989: 29; Bauman 1993: 5). In the worst case, this ethical quandary leads to decisionism, to floating responsibility, and to a fortification of the blasé feeling; it is also conducive to negativism, narcissistic frustrations, narrow commitment and to a cool indifference regarding the distinction between illusion and reality (Bauman 1993: 21ff.; Lash 1978: 47-48, 91-92). At best, the post-modern other-directed subject is left with a cynical disillusionment; namely, one experiences a contradictory state of mind where one is aware of the illusionary nature of ideology and behaves in everyday life as if one had never gotten rid of it. According to Žižek (1989: 33), this renders cynicism the prevailing ideology of today's society: even if people do not take ideological propositions seriously, even if they keep an ironical distance, they are still putting them into effect. To put it otherwise: in the contemporary cynical attitude, ideology can afford to reveal the secret of its functioning without affecting its efficiency (Žižek 1996: 200-201). From an emotions sociology point of view it could be argued that the as if stance is a feeling rule or a structure of feeling regulating emotionality and manners not only in late but also in early modernity to say the least. Let me illustrate this by referring to Bazarov, the nihilist hero of Ivan Turgenev's Fathers and Sons (1861) and the romantic Anna Sergeevna who, in an attempt to endure their longed for but miscarried love affair, frankly cast their relationship as a bygone dream and thought of love itself as a spurious imaginary feeling. They both believed they were telling the truth, Turgenev tells us. But 'was the truth, the whole truth, to be found in their words? They themselves did not know, much less could the author. But a conversation ensued between them, just as if they believed one another completely ${ }^{\prime 10}$ But why does all this happen? At the risk of simplification, in the following pages I will propose some interpretative comments.

\section{THE EXISTENTIAL QUESTION OF POSTMODERN LIFE}

In a way the postmodern condition can be interpreted as 'modernity emancipated from false consciousness' in the sense that individuals disenchant and dissolve the imaginary supports of their existence, and demystify ideological explanations by uncovering the 'truth of the truth' (Bauman 1992: ix, 188). This is a process of self-institution without illusions, as the subject learns how to live along with risks, uncertainty, contingency and negativity. If in the pre-modern and modern 
societies individuals used to misrecognize contingencies and negativities of any kind (risks, death, traumas, etc.), masking and mystifying them with imaginary ideological constructions, in late or post-modernity they tend to give meaning to their experiences through demystification and disenchantment, reconciled all the more, as it were, with the Impossible,. In view of backlash politics, the moral and existential question of the postmodern political condition is how can we transform our contingency into our destiny without giving up freedom, without relapsing into experiments of social engineering or of redemptive politics (Heller and Fehér 1988: 19).

Yet, there are certain existential boundaries to demystification; at the end of the day, one is compelled to retreat to fantasy once again, even if this is no more than a mystification of the demystification itself (Vattimo 1992: 42). To recall Nietzsche (1887/1994: 120), 'man still prefers to will nothingness, than not will'. In this respect, the cynical position offers such an imaginary cure: the cynic of today is not someone who has no illusions at all. Instead, her/his very cynical outlook, the radical skepticism, sarcasm and distrust towards all that appears as solid but melts into air, is an imaginary means to go on with his/her life in the absence of any firm and enduring moral foundation. One is compelled to think and feel that social reality exists, not in the name (or for the sake) of moral principles but simply because this is the way things are; and yet one cannot but behave as if these principles were really operative. I would say that this as if attitude is perhaps one of the last resorts for the search of meaning in the wrecked everyday life; the cynics 'know that, in their activity, they are following an illusion, but still, they are doing it' (Žižek 1989: 33). In other words, cynicism is a mode of dampening the emotional impact of anxieties through either a humorous or a world-weary response to them (Giddens 1990: 136).

\section{LEGITIMATION THROUGH DISBELIEF}

It would be too much to suggest that this sort of cynicism, which is actually an under-cover pragmatism, is the only dominant (post) ideology of our times. Both Žižek and Sloterdijk are probably one-sided, influenced by the experience of 'the really existed socialism'. Traditional hard and soft ideologies have not vanished. On the contrary, they return under new circumstances, interwoven with the electronic image, acquiring new and modified forms. Hence, I would claim that contemporary cynicism is an emotional climate that mediates all current ideological discourses. Furthermore, as a permeating emotional climate, cynicism is longterm and highly complex. As a way of defining it, I would describe cynicism, and political cynicism for that matter, as a diffused cluster emotion or sentiment which consists of a number of interwoven negative feelings and cognitions such as melancholy, pessimism, latent desperation, irony, self-pity, hopelessness, scepticism, sarcasm, guffawing, mocking, cheering, aloofness, distrust, mistrust, calculating behaviour, misanthropism, blasé relativism, bad faith, fatalism, nihilism, discontent, indignation, ressentiment, resignation, and powerlessness. 
It is not accidental, therefore, that cynicism is described as 'a position of excessive sentimentality' that leads to a melancholic and self-pitying reaction to the apparent disintegration of political and social reality (Bewes 1997: 7, 171). The cynical reaction, though, is 'insufficiently contemptuous' as it accepts the account of the world conveyed by various ideologies while rejecting it (Bewes 1997: 166, $171,199)$. In this respect, cynicism makes things worse than they are as it perpetuates the current condition (bureaucratisation, technologization, etc.), leaving the individuals with no hope (Stivers 1994: 13, 90, 180). The common feature of cynicism and idealism is that both accept reality as it is; the cynic masquerades as a realist and the idealist pretends to be hopeful. By the same token, cynicism becomes a form of legitimation through disbelief, according to Jeffrey Goldfarb's (1991: 1) ingenious suggestion. This is not a paradox; rather, it is a self-fulfilling prophesy. To the extent that no alternative is seen, the modern cynic reacts critically, sarcastically and skeptically. But the cynic's critical reaction does not focus on the distance between ideals and social and political practices; should s/he do that $\mathrm{s} /$ he would become resentful or ressentiment-ful. ${ }^{11}$ Instead, s/he casts doubt on the existence of the ideals themselves leaving the existing order of things intact. In a fatalistic way, the cynics do not believe in the ideals and principles of modern polity (i.e., freedom, equity, solidarity, democracy, etc.); they act as if they believe in them, but at the same time they know that life is a sham. Consequently, they become apologists and generators of a self-perpetuated ostensible democracy (Goldfarb 1991: 20-22, 152) and the world is no more essentially contested (Bauman 1999: 123ff.). Under these conditions, the cynic's psychic apparatus has become elastic enough to incorporate a permanent doubt as a survival factor, being well-off and miserable at the same time (Sloterdijk 1988: 5).

Criticizing Parsons' grand theory, two decades before Goldfarb, Wright Mills had perceived the incapacity of the western publics to feel at home amidst rapid societal transformations and their being driven thereafter to apathy. In his words, 'many people who are disengaged from prevailing allegiances have not acquired new ones, and so are inattentive to political concerns of any kind. They are neither radical nor reactionary. They are inactionary' (Mills 1959/2000: 41). And even when they do not panic, people often experience that 'older ways of feeling and thinking have collapsed and that newer beginnings are ambiguous to the point of moral stasis' (Mills 1959/2000: 4). In these circumstances, engaging emotions toward political authorities is becoming increasingly superfluous; the absence of 'legitimation and the prevalence of mass apathy are surely two of the central political facts about the Western societies today' (Mills 1959/2000: 41). The moral stasis he speaks about is cynicism named otherwise.

TOP DOWN AND BOTTOM UP CYNICISM

Nevertheless, despite being a complex and ubiquitous emotional climate, cynicism is not uniform. Different structural positions in a societal hierarchy may lead to different versions of cynicism, and political cynicism for that matter. 
Goldfarb (1991: 14) is crystal-clear: although cynicism is shared by the haves and the have-nots, distinct economic foundations of cynicism exist. In effect, we are dealing with two different versions of the phenomenon. This is a point rarely taken into account by mainstream political sociologists who prefer to analyze political cynicism at a rather abstract and mass level. But, as mocking and amoralistic as it may be in the first place, the cynicism of the elites is quite different from the cynicism of the powerless.

For the postmodern libertarian yuppie anything goes and there is hardly any commitment to any societal objective. S/he can be cynical in an anomic way; i.e., there is nothing to stop her/his ambitions other than those above him/herself, no sympathy, no hope, only calculated success and half-hearted enjoyment. But c'est la vie. This kind of cynicism apologises for the way things are ('they all do it'). On the other hand, for the desperate unemployed and/or the underclass, the absence of value in life is a brute fact and their cynicism is a way of dealing with hardship, a means for getting along with an unacceptable life, most likely an emotional device for bypassing and depressing their anger and shame.

On one hand, the top down cynicism of the powerful is justified by power, because they use their disregard for conventions and ideals to further accumulate power (Goldfarb 1991: 16). Democratic principles become ostensible and are observed for the sake of appearances. Stated otherwise, 'the cynical master lifts the mask, smiles at his weak adversary, and suppresses him' (Sloterdijk 1988: 111). The phrase 'Labour is liberating' (Arbeit macht frei), inscribed above the entrance to the concentration camp at Auschwitz, is one of the most striking examples of this kind of mocking cynicism. Perhaps, Dostoyevsky's Grand Inquisitor in The Brothers Karamasov is the best-ever example of the top down cynicism, a cool facilitator of power.

On the other hand, the bottom up cynicism of the subordinated represents a disillusioned miserable fate, a spiteful stance towards conspicuous consumption, and a withdrawal from a political order that they feel they cannot influence. Their ironic detachment and apathetic cynicism are more or less a defensive mechanism, a strategic resistance in the form of indifference and refuge, a way to maintain distance from a remote and immoral social and political order (Rosenau 1992: 141; Dekker 2005). Furthermore, by making lack of knowledge or power seem intentional, the cynics can gain an appearance of control of something they cannot influence in the first place (Eliasoph 1990: 473; 1998).

In this sense, I could schematically argue that the underclass cynicism is a sentimental flight rather than an emotional basis for fight, as is the case with the cynicism of the powerful. In tandem, however, they contribute to the legitimation of the system through disbelief. Furthermore, it seems to me that both stem from the wider culture of narcissism, yet not in a uniform way (Lash 1978: 31-51). Diffuse feelings of emptiness, defensive introjections to the self, depression, inability to sustain enduring relationships and committal social bonds, pessimism concerning society's future, projection of offensive drives, and inability to mourn are symptoms of narcissistic disorder at personal and societal levels. Hence, it 
wouldn't be too much to say that narcissistic personality and the culture of narcissism are the socio-psychological foundations of the cynical position.

\section{TWO VECTORS OF CYNICISM}

Though the distinction between the cynicism of the haves and the cynicism of the have-nots is ideal typical, it delineates, as it were, a political cultural difference in late modern societies. On this, Sloterdijk (1988: 217ff.) offers his notorious distinction between 'cynicism' and 'kynicism': the first is the mocking and repressing cynicism of the rulers and the ruling culture; the second is the provocative, resisting and self-fulfilling polemic of the servants. As he puts it, 'kynicism and cynicism are constants in our history, typical forms of a polemical consciousness "from below" and "from above" (1988: 218). This political cultural difference - which under certain circumstances may become division or even a cleavage (DeeganKrause 2007) - has not been studied properly by political analysts. At any rate, it intersects with another one which has a more normative and evaluative quality. It is the difference between what I would call constructive and destructive cynicism. It depicts the Janus-face of the cynical position which has evolved throughout western historical and philosophical tradition. At first glance, it could be identified with Sloterdijk's kynicism versus cynicism distinction; yet it seems to me that there is a slight but decisive difference between the two disjunctions. Though constructive cynicism draws from the 'kynical' tradition, it is not necessarily the cynicism of servants or the underclass. Conversely, despite its roots in the 'cynical' tradition, destructive cynicism is not the cynicism of the rulers by default. For example, an individual belonging to the underclass may be equally scornful and mocking to a member of his/her own group, as may be the case with someone who belongs to the ruling elite and their attitude towards a member of the underclass, and vice versa.

A few more words to explain my argument are needed at this point: on the one hand, the cynical position, as enlightened false consciousness, can lead to a critical and/or ironic distance from things, to an openness of the historical reasoning and to a toleration of what is different. ${ }^{12}$ These aspects are indispensable to the constitution and maintenance of democracy as a way of life and as an organized political system. In that sense cynicism can be seen as a mixture of healthy skepticism and political distrust. Skeptic citizens doubt rather than deny; they criticize responsibly the current performance of politicians and institutional output and are somehow optimistic about the future. Distrusting citizens still believe in the institutional framework of liberal democracy and, like skeptics, are committed to its norms and values. At the same time, they are pessimistic, suspicious and alert as to the political personnel's performance with respect to these norms and values. This combination of healthy skepticism and distrust makes citizens open to innovation and change without driving them to radical relativism and to the nihilistic belief of 'anything goes'. Therefore, this kind of cynicism does not part company with critique, self-criticism and accountability; as enlightened false consciousness it can sustain self-awareness and self-limitation away from megalomaniac, utopian 
and imaginary representations of subjectivity and political agency. Irrespective of melancholy, sarcasm, guffawing, irony, mistrust, distrust and discontent, these particular aspects of cynicism are conducive to democratic politics and societal dialogue. Hence, cynicism has a constructive character. Cynical individuals who convey these attributes still defend their citizenship in a covert or overt way and keep an eye on public affairs. Constructive cynicism can be seen as an attitude in which the assumptions of democracy are tested and scrutinized, through investigative journalism, public petitions, movements of moral protest, satirical political discourse, profanations of the political sacred, and so on (Rosenau 1992: 141; Offe 1999: 76). ${ }^{13}$

On the other hand, the cynical emotional stance can also easily lead to social and political apathy (Lyon 1994: 72), deep pessimism, cheer mocking and cold nihilism towards the values of democratic polity and civil society. The door is open now to decisionism, and authoritarian and totalitarian forms of social and political behaviour. As the existence of rational or even pragmatic criteria regulating public life is denied beforehand, the very idea of the public good and good life is at stake. Swamped in bad faith and disdain, the cynics find every political argument pointless, they lack reflexivity and exhibit an almost paranoid distrust of political personnel and decision-making processes. At their best, they are Nietzscheans and Karlschmiteans: the will to power and the aesthetization of the Political is all they think of public life (Harvey 1989: 117, 209-210; Rosenau 1992: 143). At their worst, they are bearers of ressentiment: withdrawn, inactive and alienated individuals, no discussants, know-nothings, whose political mentality is replete with negativism. Those who follow this kind of cynicism do not just deny politics, they disavow it. Hence, this cynicism is characterised as destructive.

\section{METHODOLOGICAL PERSPECTIVES}

Arguably, due to its complexity, the concept of political cynicism is a soft one. This is not necessarily detrimental to our understanding of contemporary political culture. As a soft concept, for all its elusiveness, it yearns for adequate qualitative methodologies (in-depth interviews, focus groups, ethnography, discourse analysis and so on) rather than for more sophisticated statistical models and measuring scales alone. In tandem, quantitative and qualitative methodologies will bring to light the nuances and differentiations of meaning hidden under the 'political cynicism' rubric. Deviating from the mainstream theoretical and research agenda, some scholars have attempted alternative research approaches to political cynicism. For example, in her writings, Nina Eliasoph $(1990,1996,1998)$ has shown that political cynicism is a style adopted by the less privileged citizens in order to keep distance from the above and remote centres of decision making and to cope with the hardships of their lives. William Gamson (1992: 21, 81-82, 176) documented that citizens' cynicism is not sweeping but situational. Employed as a selfdefensive mechanism, cynicism is more common in public places and among 
familiar acquaintances, such as peer groups, rather than in private environments with close friends. One could argue that the negative self-image of most men and women of the lower rankings is contingent upon the social marginalisation they experience. 'If society has castigated you for much of your life, you normally won't develop the self-confidence needed for political involvement. Rather, you will develop ... a cynicism, that produces withdrawal from social commitments' (Woshinsky 1995: 116-117). Hence, the deployment of the vitriolic and corrosive cynicism of apathy, fatalism and irony. This cynical stance is not just distrust or mistrust which could be made to succumb with the appropriate persuasion techniques. It is much deeper and complicated and it may be analyzed qualitatively by using focus groups and interviews, as Dekker did (2005) in the Dutch case. Needless to say, the tentative interpretation I offered above as to the interplay between political cynicism, guilt and shame begs for verification through grounded research.

\section{Synopsis}

A strong case was made in this chapter for an explicit articulation of the political sociology of emotions as a sub-field of 'emotions sociology' or the sociology of emotions. It is not only that many political sociologists and political theorists have carved out the space for such a disciplinary sub-field; it is also the hitherto fast growth of the sociology of emotions itself which has led to an over-diversified thematic agenda that begs for internal formatting. Far from reducing politics to affectivity, the political sociology of emotions is coterminous with political sociology itself plus the emotive angle added in the investigation of its traditional and more recent areas of research. Its raw material is the political emotions defined as lasting affective predispositions supported reciprocally by the political and social norms of a given society, playing a key role in the constitution of its political culture and the authoritative allocation of resources. Political cynicism was exemplified as a case of complex political emotion.

\section{Notes}

1 To be sure, these 'traditional' topics had been in the meantime renovated through the advent of life-politics, post-materialism, and cognitive mobilization.

2 It is to be noted, however, that while the rational choice approach exorcized emotion and affectivity from the theorizing of political action altogether, the culturalist-psychological one treated emotion in a more or less metonymic way. 'Affective orientations' and 'party identification' served as sweeping categories which accommodate distinct researchable emotions (for instance, pride, gratitude, joy, solidarity, enthusiasm, devotion, or loyalty).

3 For the characterization of a paradigm as 'normal' a set of institutional prerequisites must take place: relevant academic associations and bodies, conferences, congresses and symposia to be held in different countries worldwide, special journals, handbooks and books series, as well as university courses. All these criteria have been met in the case of the sociology of emotions. 
4 Note that in 1973 Alvin Gouldner drew attention to the sentiments' indispensable role for social theory and the analysis of ideology, kept at bay by the mainstream structuralfunctionalism of that period (Gouldner 1970: 7-9, 37-40, 205-206).

5 www.socemot.com/about_the_network/ and www.europeansociologist.org/issue-43sociology-beyond-europe/rn-reports- $\%$ E2\%80\%93-rn11-sociology-emotions.

6 Through the establishment of the International Society of Political Psychology founded in 1978, political psychology as a sub-discipline was deeply influenced by the affective turn in social science.

7 Similarly, scholars in political communication have given attention to the affective dimension of public opinion dynamics, the effects of political advertising, the construction of media events and political rituals, the setting of electoral campaigns, news media consumption, and the impact of social media in identity politics.

8 Similarly, Wahl-Jorgensen (2019: 6-8) sees emotions as actualizations of affect. Affect is viewed as a superordinate register which make possible the emergence of emotions; the latter are understood as relational embodied interpretations of affect that may be publicly named and circulated. The same happens with Slaby and Mühlhoff (2019: 38) who consider affect as a dynamic reservoir of possibility, a sphere of potential, something that is formative but not yet formed. One wonders, however, why they do not employ herein the notion of virtuality instead of possibility. For an explanation of virtuality, see Chapter 2 .

9 In this respect, the political sociology of emotions perspective decisively informs and enriches political culture study.

$10 \mathrm{https} / / /$ en.wikisource.org/wiki/Fathers_and_Sons/Chapter_25.

11 See Chapter 6.

12 Here 'irony' is understood in the spirit of Vladimir Jankélévitch (1987); namely, as a stance of modest and sensible distrust towards the outside, and as a cool disengagement towards the inside. Irony in this sense is a modality of prudence, a serious gesture of demythologization in tandem with an absence of self-complacency. For Jankélévitch irony is a mode of expression, basically an allegorical discursive strategy according to which the ironist is careful enough not to conflate the spirit and the letter of what is under scrutiny. Rorty's (1989: ch. 4) account is somehow similar but certainly poorer: the ironist doubts the validity of all vocabularies and denounces the possibility of a meta-language. His/her orientation is directed to the private realm and his/her normative objective is to limit, if not to eliminate, pain.

13 It should be remembered at this point that cynicism qua distrust is not by definition detrimental to democratic politics; liberal political theory (Hobbes, Locke, etc.) was largely founded on distrust of government (Hardin 1999, 2004). 
that it does' (Eyerman 2012/2017: 16). It conforms therefore to the process of societal and hermeneutic reflexivity (Lash 1994). And to the extent that 'cultural sociology is a kind of social psychoanalysis' with its goal being to reveal to men and women the myths they live with (Alexander 2003: 4), it is reasonable to expect that actors, members of the carrier groups, and bystanders alike, may develop agentic qualities and become more knowledgeable and creative with their own traumatic past and that of their ancestors. On this basis, we may ponder the potential of trauma driven agents to make a step from the care of the self toward solicitude for others, from Sorge to Fürsorge in Heidegger's terminology. Some of the moral derivatives of coping with trauma will be considered in Chapter 5.

\section{Synopsis}

Not infrequently, 'trauma' passes as an untheoretical term in socio-historical and political cultural analyses. Stemming from its central staging in contemporary global risk society and post-conflict environments and international affairs, on the one hand, and adopting a weak constructionist perspective, on the other, cultural trauma was construed in this chapter as a retroactive societal meaning-making process initiated by ruptures of the social fabric. These ruptures are usually caused by damaging events like wars, genocides, famines, terrorist attacks, environmental disasters, economic crises, forced migration, etc. As a trauma drama, this process involves three pivotal factors: (a) individual, group, and group-based emotions, (b) controversial policies and politics of memory, and (c) the formation of personal and collective identities. Cultural traumas are publicly narrated collective experiences of past horrendous events by carrier groups who are antagonistic with regards to the nature of the traumatogenic event and the identification of victims and perpetrators. As such they raise normative claims for possible remedy since they may either break or restore the sense of political and moral community. This account takes the discussion of trauma beyond psychological focus on individual psyches into a sociological and politicized framing.

\section{Notes}

1 Something contrary to divine law, an impious deed, sin, crime, a wretch, monster (of a person), an impossibility, and horrid! shocking! dreadful! (as interjection). See https:// latinlexicon.org/definition.php?p1=1010442 (accessed 7 June 2018).

2 Using instead the term 'historical trauma', Allen Meek defines it as 'disruptions to established forms of identity that are repeated in images and narratives and require continued negotiation and "working through"' (Meek 2010: 39). From a psychoanalytic perspective, Eugene Koh employs 'cultural trauma' in a different, naturalistic, way. He sees trauma as an infliction through which the capacity of someone to make sense of an experience is overwhelmed and therefore one is rendered frozen, or paralyzed, with regard to that particular, and other related, experiences. When this happens to the members of a particular ethnic group or cultural community, he calls it 'cultural trauma' (Koh 2019).

3 For the sake of the argument, the functional equivalent of cultural trauma in terms of historical sociology is the 'historical event'. Sewell defines it as a ramified sequence 
of occurrences that is recognized as notable by contemporaries, and that results in a durable transformation of structures (Sewell 1996: 844).

4 A fallacy held by Thomas Elsaesser (2014) who, overwhelmed by the unprecedented force of the attacks on the World Trade Centre in New York, argues that deferral and belatedness are no longer suitable for understanding trauma in the post 9/11 world insofar as the attacks marked a sudden return of referentiality (Elsaesser 2014: 307). For the cinematographic representation of the current Greek crisis in terms of trauma see Sean Homer (2019).

5 Take for instance the horrendous atrocity perpetrated by the Serbs which took place in the Bosnian city of Srebrenica during the war in Yugoslavia in 1995. For more than a decade the Bosnians, as well as other constituents of European public opinion, have been at pains to name that atrocity as genocide, while Serbia was denying it. At the end of the day, in 2007, it was The Hague International Court which characterized that atrocity as genocide without, however, putting the blame on Serbia as a state.

6 Harvey Bernard Milk (1930-1978) was an American politician and the first openly gay elected official in the history of California, where he was elected as City Supervisor for San Francisco. On 27 November 1978, Milk and the Mayor were assassinated by another city supervisor. From that time, Milk became an icon in San Francisco and a martyr in the LGBT community (https://en.wikipedia.org/wiki/Harvey_Milk).

7 This question points to a different notion of ontology than the one Alexander (2012: 14) has in mind when claiming that what is of interest in the cultural trauma theory is not the ontological reality of its basis (i.e., the accuracy of dates, events, and people's moral claims) but 'its epistemology' (i.e., that people come to believe and subjectively ascribe a meaning to hazardous and abrupt situations). My concern is about the ontological character of this belief itself.

8 With regards to informatics, this dictionary describes virtual as something 'not physically existing as such but made by software to appear to do so'.

9 As a philosopher of language, Searle considers the construction of social reality, whereas Berger and Luckman (1967), as sociologists, analyze the social construction of reality.

10 My understanding of the virtual nature of the cultural trauma construction resembles 'virtual trauma', an idea presented by Allen Meek drawing from Žižek's conception of 'virtual capitalism' and Derrida's 'virtual pace of spectrality'. Commenting on the 9/11 attacks, Meek argues that the initial incomprehensibility of the traumatic event left the space open to the communities of viewers for different interpretations of its images available on television and the internet. So, it is not only the technological nature of the visualized event that matters here but also the range of 'potentialities that may emerge out of a radical disturbance of established social and political structures' (Meek 2010: $172,186-192)$.

11 The 'universal language' of the basic emotions does not imply a naturalist conception of emotion in general. To my mind, basic emotions provide a minimum of affectivecultural universals, a thin foundation whereby an infinite array of situationally formed emotions flourish. Between the strong cases of the organic and the extreme constructionist approach, I adopt an intermediate approach of mild constructionism, based on the idea that everything is not a construction or constructable with regard to emotions. A contemporary historian summarizes what Hume, James and other great thinkers of emotions took for granted: "nearly everyone agrees that there is a biological substratum to emotions that simply cannot be denied, but emotions themselves are extremely plastic' (Rosenwein 2001: 231). See also Kövecses' (2000) formulation of 'body-based social constructionism', which he argues enables us to see anger and its counterparts as both universal and culture specific.

12 This, however, does not mean that there exists a unified psychology of traumatized communities (Koh 2019). 


\section{Synopsis}

An interpretation of the Greek civil war as an exemplary case of cultural trauma, according to the relevant middle-range theory, was attempted in this chapter. This was done through illuminating comparisons with other civil wars and by showcasing the politics of memory, the antagonistic regime of signification the war has been designated by, and the emotional dynamics during the war and after the war was over. It was argued that after a quarter of a century period of silence, the trauma drama of the Greek civil war underwent two phases: the phase of selective construction (1974-1990), and the reflexive construction phase (1990 onwards). Currently, the trauma drama of that war molds much of the political identity formation processes in Greece as its legacies are evidenced in public memory and emotionality.

\section{Notes}

1 On 5 March 1946 Churchill demarcated East versus West with his notorious 'Iron Curtain' statement; the Truman Doctrine and Marshall Plan followed some months later. Their timing chimed with two crucial incidents of the Greek civil war. 30 March 1946 is conventionally understood as the date on which the conflict began, and in September 1947, with USSR backing, the Greek Communist Party led the war to its climax (the limnes [lakes] plan which aimed at the secession of a region in the northern part of the country which was to be declared a popular democracy).

2 These divisions were much less intense than the intersecting cleavages which fueled the Spanish civil war (regional/ethnic differences, Catholics versus anticlerical groups, class conflicts), or the Finnish civil war which had a much more solid class basis due to the strong organizational unity of the Finnish workers' movement (Alapuro 2002).

3 See also Chapter 5 on this.

4 Though exact numbers cannot be defined, it is estimated that approximately 100,000 people died due to the famine (Fleischer 1986; Hondros 1983) To be sure however, one should not exaggerate with the long last destructive consequences of the occupation as these were used in the construction of the post war victimization of the nations involved. After the war, almost each country constructed a powerful myth about the 'unprecedented destructions' it suffered by the enemy, suppressing thus from the public memory the thorns of collaboration, the toleration of the Jewish genocide and ethnic cleansings executed either by the Axis forces or the Resistance, as well as alignment with the occupation forces.

5 With one of her elder sisters, in early 1942 at the age of 14, my own mother was forced by the Bulgarian occupation authorities to move from the northern Aegean island of Thassos to Athens where she had a first-hand experience of the famine.

6 For quite different reasons, the Baltic countries do not celebrate 8 May either; for them the real liberation came in 1991 when the Soviet empire collapsed.

7 Large parts of these geographical areas which had been under the Ottoman rule from the sixteenth until the early twentieth centuries belong now to the Greek nationstate as a result of the Balkan Wars (1912-1913) and the World War I resolutions. KKE's policy for an independent Macedonia and Thrace state met public outrage because, if for no other reason, it was just a few years beforehand that these territories had been annexed to the Greek state after bloody wars supported by a widespread irredentist ideology. Nationalist sensibilities over the so-called Macedonian Question challenge not only the Greek public opinion of today, but also Bulgarian 
foreign policy, and - of course - the citizens and the governments of the Republic of North Macedonia. This country's population of approximately two million people consists first of inhabitants of Slavic and, second, of Albanian ethnic origin, with Romani, Serbian, Turkish and Bulgarian minorities making up a much smaller part of the population. An overarching Macedonian nationality is supposed to politically bridge these ethnic differences. See among others Demertzis et al. (1999) and https://en.wikipedia.org/wiki/Macedonia_naming_dispute https://en.wikipedia.org/ wiki/Republic_of_Macedonia.

8 However, that was not the case with the Katyn massacre in 1939. For almost 50 years the socialist regime forcibly imposed silence concerning the fact that the crime was committed by the Soviets rather than the Nazis. See Bartmanski and Eyerman (2013).

9 This discursive gesture, however, was not followed by any sort of formal or informal reconciliation committee, body, tribune, dialogic process, etc.

10 A similar binary remembrance was put into effect in Poland with regards to the Katyn massacre and in Mao's China with regard to the massive atrocities of the Japanese army (Bartmanski and Eyerman 2013; Gao 2013). Yet, it seems to me to be misleading to draw too sharp a line between the official/public and the collective/popular memory; in the on-going hegemony process, bridges are built and various kinds of overlapping are formed.

11 Implementing an 'integrated plan of commemoration', a similar effort has been taking place in Spain over the last ten years or so. The names of high-profile streets and squares, dedicated to Francisco Franco, the dictator who ruled Spain from 1939 to 1975, as well as to generals (e.g., Yagüe, Mola, Varela, Fanjul) who took part in the military uprising against the Spanish republic in 1936, and who served under Franco in the bloody civil war, have been changed as a result of the so-called historical memory law that was passed under the socialist government of José Luis Zapatero in 2007 (www.ft.com/content/b7bb4a8a-a8d2-11e5-955c-1e1d6de94879).

12 This was not initiated from below; it was implemented top-down by public authorities. Monuments and memorials offer official recognition and create sites of memory and commemoration. Yet, since monument and memorial are not designated by two different words in Greek, it is not clear whether this statue is to commemorate the occurrence of the civil war or remember those who died in it. As Arthur Danto maintained, 'we erect monuments so that we shall always remember, and build memorials so that we shall never forget' (Danto 1985: 152 - cited by Eyerman et al. 2017: 23).

13 Similarly, in the trauma drama of 1974 in Cyprus, the Turkish military aggression overshadows the memory of the Greek-Cypriot coup against the legal government of the island, which actually triggered the Turkish invasion and sparked a short but harsh filial conflict just before the invasion. See Roudometof and Christou (2013).

14 I guess the same kind of bitterness is harboured by the followers of the US Confederacy who have been recently witnessed the removal of many monuments and memorials from a good number of American cities in the wake of the Charleston church shooting in June 2015. These removals - not destructions - as spectacular as they may be, including statues of prominent figures like Robert E. Lee and Nathan Bedford Forrest, are a clear sign against white supremacy and nostalgia for the good old days of the slavery that was defended by the big farmers and troops of the South during the American Civil War. In a divided emotional atmosphere, the public in the United Stated seems to be still tormented by the civil war. See among others https://en.wikipedia. org/wiki/Removal_of_Confederate_monuments_and_memorials\#Florida.

15 Clearly, the civil war is not unique in terms of the British and US involvement; one can find similar stories in Palestine and Israel, India, Cyprus and so on, according to the divide and conquer politics. The point is that this involvement has been imaginarily overstated. 
16 A note of caution is needed at this point. I do not aim to counterbalance the suffering of the two major actors, nor do I wish to make up for each one's political responsibilities. If anything, I am principally interested in how and not why the war was carried out, and not whose fault it was.

17 Likewise, the dominant account of the civil war in today's Finland resides in a seemingly inconceivable revolt by a part of the people 'against itself', broadcasting the cause of the war outside the nation - Reds were 'infected' or 'misled' by the Russians to betray their own fatherland (Alapuro 2002).

18 www.myfilm.gr/6361.html. The success of the film in generating public dialogue about the civil war can be compared to both Wajda's movie Katyn, which in Poland narrated more than anything else in the past the need for the memorization of the massacred victims (Bartmanski and Eyerman 2013) and the performance of Beckett's play Waiting for Godot in Sarajevo and New Orleans as a symbolic means for the construction of vicarious trauma (Breese 2013).

19 Lately, very few intellectuals of the Left have deviated from this justifying discourse by discreetly referring to the civil war as a strategic political option carried out by the Greek Communist Party in the 1940s and not as a fatal tragedy of the Greek people as a whole. In June 2018, 73 years after his death, KKE officially restored Velouchiotis, admitting that his deletion was a mistake and that his political choices then were in the right direction.

20 This has been recently witnessed in the cases of Iraq and Syria where civil and inter-ethnic conflicts coexisted with resistance to the American, British, and Russian troops.

21 www.bertelsmann-stiftung.de/en/publications/publication/did/social-justice-in-the-euindex-report-2017-1/

22 This holds true for contemporary Spain. In July 2018 the Socialist prime minister Pedro Sánchez ordered by decree the immediate removal of General Franco's remains from his tomb in the grandiose basilica at the Valle de los Caídos (Valley of the Fallen) to a more modest burial place. This decision, 80 years after the end of the civil war, ignited heated disputes over its meaning and political usage. (www.nytimes.com/2018/07/07/ world/europe/spain-franco.html). In the 28 April 2019 election, profiting, among others, from those disputes, the newly formed far-right party Vox took 10.26 percent of the vote and 24 seats in Parliament and managed to become the first far-right grouping to win more than a single seat in Congress since Spain returned to democracy after the fall of Franco in 1975. Eventually, Franco's remains were exhumed on 24 October 2019; the exhumation took place ahead of a repeat national election on 10 November the same year. There were voices against that and voices protesting that real reparations for the civil war and the dictatorship never happened (www.nytimes.com/2019/10/24/ world/europe/franco-exhumed.html). 
communication. It also accounted for the ways emotions have been treated in media scholarship. It was argued that, for the most part, the mediatization of others' traumas gives rise to 'quasi-emotions' which are part and parcel of the spectacularization of suffering; however, it was also argued that there is space for full-fledged emotions like sympathy and compassion for the victims and anger, resentment, or disgust for the wrongdoers to give rise to support thereafter for a possible 'politics of pity'. While it has strong unintended consequences in foreign affairs, the politics of pity at the grassroots may occasionally inform decision making in a more reflexive way. This moral-emotional function of the media is feasible through the emergence of 'moral universals' despite widespread cynicism and apathy.

\section{Notes}

1 In an attempt to delineate the sub-field of the sociology of emotions, four chapters of the reader edited by Greco and Stenner (2008) focus on the relations between the media and emotions.

2 This has been systematically documented by Döveling, von Scheve and Konijn (2011), where a multilayered and multi-disciplinary approach of the media-emotions nexus is accomplished with media psychology staging high in the analyses of different topics.

3 From a different perspective directed by the premises of war studies, Nico Carpentier's edited volume (2007) touches upon a number of issues raised in this chapter.

4 These issues refer to the essentials of moral philosophy and entail a host of conceptual controversies as to the meaning of compassion, pity, fellow-feeling and the like. See: Scheler (1954), Sznaider (1998), Hoggett (2006), Nussbaum (2001) and Höijer (2003).

5 For the latter, exposure to traumatic images can function as a "challenge to turn our attention to, to think, to learn, to check the explanations invoked by those in power in order to justify collective pain' (Sontag 2003: 121-122).

6 In this respect, not only the members of the audience but journalists themselves often become desensitized in the face of mass suffering (Milka and Warfield 2017). In any case, their work requires extensive emotional labor (Wahl-Jorgensen 2019: 39).

7 Anyhow, the emotional underpinnings of news media political communication of any kind whatsoever have only recently started to be empirically scrutinized (Otto et al. 2019).

8 September 11 made clear that when it comes to 'our' trauma, American media and journalists adopt a much less melodramatic and entertaining stance (Rosen 2002).

9 Setting out from a perpetual remorse for modernity's dark side (colonialism, world wars, environmental degradation, etc.) westerners over-react, Pascal Bruckner claims, with regards to guilty conscience and sympathy expressed for the less fortunate of this world, as if the latter are relieved of all responsibility for their situation. But selfdenigration is a kind of indirect and no less megalomaniac self-glorification: the West is the master and destroyer of the planet in toto and in this respect the western citizen cannot or should not feel guilty for his/her mighty position (Bruckner 2010: 35, 42).

10 This feeling Smith calls 'sympathy'. A more extended discussion on Smith's moral sentiments is to follow in Chapter 6.

11 Arguably, empty empathy, as understood by Kaplan, is cause and effect of 'quasiemotions', as described by Meštrović (1997).

12 Although both were much influenced by Levinasian ethics, Silverstone's optimistic idea of 'mediapolis' stands opposite to Bauman's 'telecity' where moral relationships of responsibility are superseded by aesthetics and entertainment. 'In the telecity, the 
others appear solely as objects of enjoyment.... Offering amusement is their only right to exist' (Bauman 1993: 178).

13 Silverstone actually adopts Jonas' idea of being someone responsible even for the actions of one's enemies within the mediapolis, inviting thereby Daniel Dayan's critical insinuation that this is ultimately a heavenly and not an earthy stance, characterized by moral maximalism (Dayan 2007: 117, 119).

14 To take an example, stemming from film and photography studies and post-structuralist theorizations, Meek (2010) scrutinizes the blurring of media logic and traumatic logic in the case of 9/11 mainly without, however, coping with spectators' own reception of trauma images. 
criteria regulating public life is denied beforehand and, consequently, the very idea of the public good and good life is at stake. By and large, this tendency is pushed and pulled by the post-emotionality of contemporary western society (Meštrović 1997) referred to in the previous chapter. Social isolation, powerlessness, visual culture, and consumerist individualism drive many people to experience inauthentic emotions in the sense that they do not commit themselves to what they really feel. Oftentimes this ends in a kind of blasé affective experience and a cynical attitude. As we mentioned in Chapter 1, swamped in bad faith and disdain, many cynics find every political argument pointless and they lack reflexivity and exhibit an almost paranoid distrust of political personnel and decision-making processes. Ultimately, they are indifferent to either good or evil (Lipowatz 2014: 309). Under these terms, there is no place in their hermeneutic horizon for the virtue of forgiveness and they do not believe in sin anyway.

Last but not least, one should take into account that the modern Greek designation for 'forgiveness' is sunchorese ( $\sigma 0 \gamma \chi \omega ́ \rho \varepsilon \sigma \eta)$, which comes directly from the ancient Greek word sunchorein ( $\sigma \gamma \gamma \chi \omega \rho \varepsilon i v)$ ), which means 'to be together with others at the same place'. This cannot be accomplished without some sort of societal reflexivity.

\section{Synopsis}

This chapter discussed forgiveness as an alternative moral-emotional response to trauma next to retaliatory revenge, justice, and non-forgiveness. Amidst a widespread emotional climate of cynicism on the one hand and a permeating therapeutic culture on the other, forgiveness stands as a moral virtue to be differentiated from ostensible apologies and pardons premised on political imperatives in postconflict societies as well as from forgetting and social amnesia. With respect to trauma drama, the affectivity of forgiveness is related to mourning, emotional reflexivity and free will. Drawing, among others, from Jankélévitch, Arendt, Ricœur, Derrida, and Nussbaum, the chapter keeps a distance from the Abrahamic tradition, assessing forgiveness as a secular moral virtue, as an 'imperfect duty', to be performed toward the right persons, in the right manner and at right times.

\section{Notes}

1 www.rimini-protokoll.de/website/en/.

2 www.sgt.gr/eng/SPG1385/?.

3 https://fr.wikipedia.org/wiki/Rainer_H\%C3\%B6ss.

4 www.sgt.gr/eng/SPG1546/?.

5 www.tovima.gr/opinions/article/?aid=796163.

6 www.sanmetodio.eu/index.php.

7 These responses may be articulated in a secular, religious, or semi-religious spirit; arguably, they are not the only ones. There are other moral reactions too, that are worthy of in-depth commentary as they assume some form of theodicity. Among these are: (a) faith in a God who created and gave away the world out of love while at the same time letting humanity be really free to choose between good and evil; in this case, the 
subject does not resign or withdraw but drastically makes decisions guided by memory, reason, and will; (b) active hope in the sense of the religious eschatology of the Final Judgment and the concomitant endurance of suffering and evil in the world, irrespective of evil harbored or evil caused by the subject (Lipowatz 2014: 426-433; Ricoeur 2004a).

8 https://quizlet.com/137807274/aristotle-rhetoric-the-emotions-flash-cards/.

9 Nussbaum's moral rationality is contiguous with Habermas' communicative rationality and what some sociologists of emotions call 'emotional reflexivity', e.g., Holmes (2010) and Burkitt (2012).

10 It should be noted however that, in spite of its immediacy, jus talionis curtails the possible arbitrariness of wild spontaneous revenge, on the one hand, while legally equalizing the powerful and the powerless, on the other; in this sense, it contributes to societal stabilization.

11 Conflating revenge and retribution somewhat, Elster (2006) spoke of five 'retributive emotions': anger, hatred, indignation, and contempt directed at the perpetrators, as well as pity for the victims.

12 Traumatogenic victimization as a derivative personality trait grounded on narcissistic wounds is somewhat relevant to the victimization Pascal Bruckner speaks about as a strategy to get away with duties and responsibilities (Bruckner 2000).

13 www.forgiveness-institute.org.

14 Wrongs fully excused are not blameworthy since there is nothing to forgive. As a lawful lawlessness derived from the monarchical tradition, official pardon or clemency is exercised by third parties as opposed to the victims; legal or political pardons reduce or even eliminate punishment, whereas forgiveness need not affect punishment whatsoever (Sarat and Hussain 2007: 6-7). In condonation one overlooks a wrong as if it did not exist or did not actually occur. Thus, condonation is a form of tolerating wrongdoing (Hughes 2016).

15 In cultural anthropology the emic perspective is seeing things from the actor's point of view whereas the etic perspective is the stance of the researcher trying to explain social realities using the theoretical concepts of social sciences (Geertz 1973: 14-15).

16 On this basis there is an ideal typical distinction in the relevant literature between intrapersonal decisional and emotional forgiveness. In emotional forgiveness there is a replacement of negative unforgiving emotions such as hatred and anger by positive ones like empathy, acceptance, etc. (Wade et al. 2005; Worthington and Cowden 2017).

17 Empathy is an emotional response arising from the apprehension of another's emotional state and it is very similar, if not identical, to what the other person is feeling (Eisenberg 2004: 677); therefore, it is someone's ability to imagine how the other feels in a certain situation (Ben-Ze'ev 2000: 108, 110). In contrast, in sympathy, the subject does not feel the same or almost the same feeling as the other person, but sorrow or concern for the other's misfortune (Eisenberg 2004: 678). Thus, sympathy is the counterpart in one person of another's sense of loss, sorrow, discomfort, abuse, and the like (Schmitt and Clark 2006: 469). See also Scheler (1954) and Smith (1976).

18 www.un.org/en/holocaustremembrance/2016/calendar2016.html.

19 Stepping on the same ground, in his Lost Illusions Honoré de Balzac thinks of repentance as a sort of indemnity for wrongdoing and as a means for absolution when gestured more than once. 'Repentance is virginity of the soul, which we must keep for God'; yet, periodical repentance is a great hypocrisy and 'a man who repents twice is a horrible sycophant' (de Balzac 2004: 496).

20 Counterpointing conditionality and unconditionality is a familiar philosophical stratagem found in Derrida's work. As with forgiveness, he discusses hospitality in exactly the same way: hospitality is certainly a moral gesture but it gains its ultimate value 
when it is offered beyond any legal prerequisites as an unconditional welcome to the foreigner (Dufourmantelle and Derrida 2000).

21 Yet, for all his deconstructive demeanor and although he points out that only the victims have the right to forgive or not to forgive, he seems to endorse the idea that the Shoah is an instance of transgression that cannot be pardoned (Shoah Resource Center, 1998).

22 The Abrahamic tradition on the issue of forgiveness brings together Judaism, Christianity, and Islam.

23 It makes also a difference whether the issue of non-forgiveness is raised in low context individualist or high context collectivist cultural contexts (Ting-Toomey 1994; Worthington and Cowden 2017). In collectivist cultures it is reconciliation based on interpersonal and institutional trust which counts more than forgiveness. The latter is regarded as an atomistic gesture.

24 Namely, as the morality of the inferior. Chapter 6 details ressentiment in relation to resentment.

25 http://depts.washington.edu/vienna/literature/polgar/Biography.htm.

26 Thinking of resentment as moral anger linked to self-respect, Jeffry Murphy (1998: 17) contends that 'a too ready tendency to forgive may properly be regarded as a vice because it may be a sign that one lacks respect for oneself'. 
ressentiment are: not acted out vindictiveness, chronic interiorized powerlessness, a gap between legal rights and real entitlement, social comparison, and injustice experienced as destiny. Special emphasis is put on the political repercussions of ressentiment depicted from different historical contexts. Argumentation is supported by recurrent references to novels and autobiographies showcasing the composition of ressentiment and its roots in individual and societal dynamics.

\section{Notes}

1 Bishop Joseph Butler, to whom Hume owes a lot, preached that resentment has been implanted in man by God himself according to the Divine Providence. As an Enlightenment philosopher, Hume replaces God with Nature.

2 To be sure, however, Josef Butler distinguished between what he called 'hasty and sudden' and 'settled and deliberate' resentment (Butler, Sermon IIIV \& IX). The first is sheer anger caused by harm; the second a remedial reaction against injuries, vice, and wickedness deemed as 'one of the common bonds, by which society is held together; a fellow feeling which each individual has in behalf of the whole species, as well as of himself'.

3 The issue of course is immense and cannot be given adequate treatment here, but suffice it to mention that Smith's impartial spectator shares much with Kant's Categorical Imperative. Just indicatively, see Fleischacker (1991).

4 It seems that this expectation is the hallmark of what Simone Weil (1962: 10) calls 'the sacred'. In her own words:

There is at the bottom of every human heart something that goes on expecting, from infancy to the grave, that good and not evil will be done to us, despite the experience of crimes committed, suffered, and observed. This above all else is what is sacred in every human being.

The good is the only source of the sacred. There is nothing sacred except the good and what pertains to it'.

5 'both my description of, and my name for, these attitudes are a little misleading' (ibid).

6 From a utilitarian moral psychological perspective, Joshua David Greene assumes that there is an inbuilt sense of justice that makes cooperation within groups possible. Together with other moral stances, it has been cultivated through natural selection (Greene 2013).

7 Collective emotions are experienced concurrently with others while group-based emotions are experienced on the basis of group identification, either alone or with other group members.

8 In the same vein, resentment was conceptualized as righteous indignation by Sennett and Cobb $(1972: 117-118,139,148)$ in their study of the post-World War II American working-class consciousness.

9 On the contrary, Dennis Smith (2006) sees resentment as an exclusively emotional reaction to humiliation experienced as an undeserved social displacement that may occur by conquest, exclusion or relegation.

10 Nussbaum (2016: 262-263) actually dismisses resentment as a moral emotion as long as she holds that wrongdoings frequently call upon a payback wish inherent in anger.

11 In his comprehensive doctoral dissertation, holding that resentment differs from indignation insofar as the latter responds to impersonal wrongs and the former to personal inflictions, Sébastien Aeschbach diverges from the moral philosophical tradition which takes indignation as resentment against undeserved and unjust suffering 
of sympathetic third persons. Confining resentment within the interpersonal cycles of interaction only, his definition goes as follows: (1) it is a kind of anger which is aroused when one is wronged; (2) it necessarily involves a desire for revenge; (3) it has the injustice of an unremedied wrong as its 'formal' object; (4) it has persons and their action as its 'proper' object (Aeschbach 2017: 13).

12 Ten years before, Elster (1989: 61) had initially welcomed the use of emotions in social analysis, thinking of them as the 'stuff of life' since 'creatures without emotions would have no reason for living'. For all his inspiring but no less brief argumentation over emotions, it was excessive on his part to claim that 'the importance of emotions in human life is matched only by the neglect they have suffered at the hands of philosophers and social scientists' (1989: 61).

13 Aaron Ben-Ze'ev relies on an individual level of analysis when it comes to resentment; he sees it as an emotional protest against perceived injustice and moral wrongdoing inflicted by other people who are held responsible. The perception of injustice occurs amidst downward interindividual comparisons. In this context, 'when we feel resentment the focus of attention is the other's improper activity, but the focus of concern may be its implications for our own status'; thus, unlike anger, hate, envy, and forgiveness, resentment is directed to the action rather than the actor herself. It lasts quite a lot longer than anger and it differs from envy because it focuses on the wrongfulness of our inferior situation and not on the inferiority as such; it conveys therefore a public and private accusation (Ben-Ze'ev 2000: 31, 283-284, 396, 465, 507).

14 Employing the term 'ressentiment-ful person' or the 'man of ressentiment' might give the impression that I am referring to a role performance or a process of self-formation rather than to a composite sentiment. The truth is that I am using these terms colloquially, following some of my sources' terminology and certainly Scheler's own vocabulary. Scheler viewed ressentiment as fuelling different social roles like that of the spinster, the elder, the mother-in-law, the bourgeois vs the aristocrat, the retired official and so on. Jack Barbalet drew my attention to this issue.

15 It should be noted that when his book, originally entitled Über Ressentiment und moralisches Werturteil, appeared in 1912 (in 1915 it was republished under its final title Das Ressentiment im Aufbau der Moralen), Scheler was a deeply concerned and selfquestioning Protestant who later on (1920) turned to Catholicism which he would soon abandon (1924) to espouse a vitalistic and no less pantheistic position. It is due to his philosophic Catholicism that he defended so ardently Christian love and morality.

16 However, insofar as Classical Enlightenment (Kant, Hegel, etc.) is not reduced to cheap and mundane versions of market-oriented liberalism and authoritarian socialism, Scheler seems to over-generalize his critique to encompass Enlightenment and Modernity in toto.

17 Compared with Aristotle's account of anger, the ressentiment-ful person in its Nietzschean version is an angry person, although not in an open way precisely because anger is 'attended by a certain pleasure - that which arises from the expectation of revenge' and 'by a certain pleasure because the thoughts dwell upon the act of vengeance, and the images then called up cause pleasure, like the images called up in dreams' (Rhetoric 1378b); on the contrary, the Schelerian version of the ressentiment-ful person is not and cannot be angry because the very imagination of revenge has already been repressed beforehand.

18 Class hatred could be viewed as a sort of compensatory conduct through which those who lack economic and cultural resources can claim some superiority (Sayer 2005: 183).

19 "The "equality of souls before God" - this fraud, this pretext for the rancunes of all the base-minded - this explosive concept, ending in revolution, the modern idea, and the notion of overthrowing the whole social order - this is Christian dynamite' (Nietzsche 1895/2014: Chapter 62). 
20 It seems that Adam Smith's notion of envy deflects from the egalitarian assumption since he defines it as 'that passion which views with malignant dislike the superiority of those who are really entitled to all the superiority they possess' (Smith 1759/1976: 244).

21 For Vincent de Gaulejac (1987), class neurosis is the intersection of an individual's blocked psycho-sexual development with the blockage of the social self under conditions of downward and/or upward social mobility.

22 Nevertheless, she admits that her promise to herself never to desire to be white did nothing 'to drive away the wish dreams that filled my head whenever my desires collided with a taboo. So, in order that my daydreams [did] not contradict my principles, I constructed a fantasy in which I would slip on a white face and go unceremoniously into the theatre or amusement park or wherever I wanted to go. After thoroughly enjoying the activity, I would make a dramatic, grandstand appearance before the white racists and with a sweeping gesture, rip off the white face, laugh wildly and call them all fools' (Davis 1988: 85).

23 I use 'ressentiment' as the translation of Ferrante's 'rancore' (rancor).

24 It might be argued that praising something is also part of repression and negation, not merely a consequence of these. Its function is convincing oneself more than others. I owe this insight to Mikko Salmela.

25 Together with other nineteenth-century thinkers such as Louis Blanqui, Abel Rey and J. M. Guyau, who advocated a cyclical cosmological view, Gustav Le Bon might have in turn influenced Nietzsche in formulating the idea of eternal recurrence (Williams 1952: 109; Brandes 1972: 49).

26 Bien que s'y mélangeant de plus en plus, elle se sentait, néanmoins, tenue à distance et en éprouvait un vif ressentiment (Le Bon 1912: 59).

27 The book was translated and edited in English very shortly after by Mortimer Epstein with the title The Quintessence of Capitalism: A Study of the History and Psychology of the Modern Business Man. New York: E. P. Dutton, 1915. In 1998 it reappeared as a Routledge Publication and was translated and edited in Greek. References are to the Greek edition.

28 Von Martin, Soziologie der Renaissance. Zur Physiognomik und Rhythmik bürgerlicher Kultur. Enke, Stuttgart 1932. For the needs of the analysis herein I used the 2016 German edition and the 1944 English translation. The Sociology of the Renaissance has long been a touch point for students of the Renaissance period. Be it noted that in the 1944 English translation Ressentiment was translated either as 'reaction' or as 'bitter resentment' (von Martin 1944: 36, 44, 45) meaning probably that the thematization of Nietzsche in British sociological vocabularies of that time was limited.

29 'So kommt es zu dem inneren Aufstand der sich aus Einzelnen - und sich ihrer Einzelheit mit Stolz Bewusten - zusammensetzenden burgerlichen Intelligenz gegen die Masse des Burgertums, insbesondere gegen das Burgertum als Handelsstand, als kaufmannischen Berufsstand. Der Mann, der uber nur geistiges Kapital verfugt und von ihm leben will, wirdzwar erst auf burgerlichem Boden moglich; aber er fuhlt sich doch zumeist vom Burgertum, unten gehalten und reagiert mit Ressentiment gegen eine allzu burgerliche Geistverachtung bei der besitzenden, wirtschaftlich erwerbenden und politisch machtigen Schicht' (Martin 2016: 50).

30 This, however, does not preclude the possibility that both resentment and ressentiment may arise from major wrongdoings.

31 Aeschbach (2017) has done terrific work to this end from a philosophical point of view, focusing mainly on the phenomenology of ressentiment.

32 See for example Roger Scruton's (mis)treatment of the Nietzschean ressentiment in his interpretation of totalitarianism. He merges resentment and ressentiment and states that Nietzsche himself 'would perhaps not have recognized' the way he uses the notion. Of course, as Meltzer and Musolf (2002) claim one should not reify concepts but the 
crucial issue here is how much one is entitled to change them without losing their historicity, distinctiveness and clarity. Transvaluation is a sine qua non for the conceptual constitution of ressentiment and Scruton (2006) dismisses it altogether.

33 Aeschbach $(2017: 10,50,258,69)$ oscillates between thinking of ressentiment as a "psychological mechanism that manipulates evaluations in a certain way with the goal of feeling better about oneself' or as the 'very mechanism that transmutes envy into moral emotions such as resentment and indignation', and as a long-lasting complex sentiment.

34 In their latest contribution, Salmela and von Scheve (2018) stress that social sharing of the transformed emotions which make up ressentiment reinforces the entire value transmutation process toward specific targets.

35 Thus confesses Dostoyevsky's mouse man: '... secretly, inwardly gnawing, gnawing at myself for it, tearing and consuming myself till at last the bitterness turned into a sort of shameful accursed sweetness, and at last - into positive real enjoyment! Yes, into enjoyment, into enjoyment! I insist upon that' (Dostoyevsky 1864/2000: 10).

36 He did not, however, set ressentiment apart from resentment; as a particular kind of political resentment, he viewed it as 'the second most powerful political emotion after instability' that 'really corrodes societies' (Yankelovich 2009: 26).

37 The same holds true for hatred, though not entirely, because one can hate a particular person in isolation and not just types of people, groups or categories; yet repressed hatred serves as a substrate from which ressentiment may spring forth. See, among others, Nussbaum (2016: 50) and Brudholm (2010). Hatred is likely to emerge from repressed anger that the person or group is not capable of expressing or acting out in a satisfying manner (Halperin et al. 2011).

38 In their qualitative study Hoggett, Wilkinson, and Beedell (2013) found resentment and grievance to be much more directed at one's 'neighbour' than at powerful but less visible groups and elites. They also found that their informant's ressentiment was objectless and expressed via a general complaining tone directed towards 'the authorities' and to categories of people perceived as being different (single parent, ex-offender, mentally ill, having special needs).

39 The symbol '=' means 'results from' and the symbol ' $\&$ ' means 'and' or 'joined with' (TenHouten 2007: 51).

40 Viewing ressentiment as a form of generalized resentment, TenHouten (2018: 10) maintains that it is comprised of the same three primary emotions (anger, surprise, disgust) and the same three secondary emotions (contempt, shock, and outrage) that resentment consists of. He also states that ressentiment is typically accompanied by other complex emotions and affective states of mind, which can vary greatly by situation and circumstance, such as vengefulness, hatred, bitterness, and malevolence. In view of Scheler's analysis, I do not think that TenHouten's position is valid as long as he disregards that the crux of ressentiment itself are those complex emotions which are allegedly circumstantial to its emergence.

41 Schadenfreude is a culture-specific emotion, meaning that, quite apart from the occurrence of punishment, the resenter takes pleasure in all bad things that rightfully happen to her/his wrongdoer. TenHouten has not thematized this emotion but one can safely use his equation and treat it as a tertiary emotion. For a sharp-witted analysis of Schadenfreude - which is also a terminus technicus - see Portman (2000) and Dijk and Ouwerkerk (2014). Emphasis should be placed here on 'rightfully', on the sense of justice that accompanies the vindictive joy one experiences facing the sufferings of a third person ('he asked for it', 'he should have watched his step'). If it wasn't for the dimension of justice we would be dealing simply with grudgingness or malice.

42 Adopting the position of the victim and endowed with a particular sense of moral superiority, the ressentiment-imbued persons imagine that they have all the virtue on their side, it is the other that is the villain, wrong, guilty, etc. (Hoggett, Wilkinson, Beedell 2013: 578). 
43 Turning upside down the Nietzschean approach, Solomon (1994) claims that transvaluation qua passivity is a strategy of the will to power that is specific to the weak. Consequently, powerlessness is not seen as a cause of ressentiment but as an outer manifestation of the weak persons' eagerness to take revenge in their own terms, as an expression of their own will to power. For Solomon ressentiment is the ever most clever and life-preserving emotion of the slave in his confrontation with the master. From a psycho-political perspective Tadej Pirc denounces this posture, claiming that Solomon has 'caught himself in the very web of the slaves' revolt in morality' which results from a double castration: the castrating lack of efficiency, and the castration of 'the master morality by the downtrodden' (Pirc 2018: 125).

44 At this particular point Meltzer and Musolf (2002: 244) discern a contradiction in Scheler's thesis without however really taking into account his account of transvaluation. Having done this, they would mix up resentment and ressentiment.

45 Although Albert Camus was well aware of Scheler's work, admitting that revolutionary rebellion is more than oftentimes contaminated with ressentiment, he nevertheless wished for an existential rebellious stance against the Absurd, cleansed of any trace of ressentiment. Revolution should be pure love and fecundity or it is nothing at all. Instead or rancor, malice and tyranny, Revolution should be an affirmation of life by men of flesh and blood, a passionate self-assertion and one's own creation of the Self premised on values that exceed the individual for the sake of a transcendental good; on this basis, Camus was at pains to 'understand why Scheler completely identifies the spirit of rebellion with ressentiment' (Camus 1991: 304-305, 18). Ultimately, Camus' L'Homme révolté and Sisyphe are one of a kind representing 'the "yes-saying" or loving attitude towards existence as opposed to the "nay-saying" attitude of the Nietzschean men of ressentiment' (Novello 2015: 12). Note that the translator of The Rebel substituted ressentiment in the original text for resentment, thus blurring Camus' argument for the English-speaking reader.

46 In a way then one is to wonder whether ressentiment is the father or the child of modernity. But I think this is more a kind of metaphor rather than an accurate interpretation of the complex emotional underpinnings of modernity (Becker 2009).

47 For a similar interpretation of Islamic terrorism alongside Scheler's account of ressentiment see Manfred Frings (2005).

48 See Chapter 1 on political cynicism as political emotion.

49 This is the way Ferro (2010) treats ressentiment and that is probably why his translator accounted for it as 'resentment' as indicated earlier in this chapter. He uses it as a catchall or metaphoric notion conveying actual envy, resentment, jealousy, anger, and rage. For a similar critique see Aeschbach (2017: 253) who says that Ferro either has resentment in mind or fails to distinguish the phenomenon of ressentiment from resentment when discussing his cases.

50 In a more systematic way, Mario Wenning criticizes Sloterdijk's position as reformist because it suffocates productive rage rather than organizing it for the right causes. Sloterdijk's argument is based on a historical optimism that is difficult to reconcile with a political reality replete with blatant injustice which requires something more than an unconditional trust in civilizational learning processes (Wenning 2009: 97).

51 Relatedly, Greenfeld and Eastwood (2005: 263) holds that ressentiment serves as a decisive motive behind ethnic nationalist liberation movements.

52 Conflating the twin emotions, on the one hand and dismissing altogether the importance of the defense transvaluation process on the other, Mann and Fenton speak ultimately of envy rather than resentment or ressentiment. They attempt to relate class identities and resentfully based nationalism as they are reflected and mediated in contemporary British electoral politics.

53 For a psychoanalytic perspective, see David Levine (2018). 
theoretical analyses. And of course, pointing to emotions in populism research what is of real interest is not the psychosomatic etiology of individual affective dispositions - what William James once called 'medical materialism' - but their inter-subjective and moral significance. This makes for the in-situ interpretation of the meanings involved in the supply and the demand side of political populisms. Such an interpretation begs for the most appropriate theoretical approaches to be drawn from the theoretical and conceptual pool of the sociology of emotions on the one hand, and for sound and solid methodological triangulation on the other. What is more, one should take into account the concrete local, national or international political cultural landscapes where the populist phenomena occur and at the same time make sure that the level of analysis goes beyond the individual scale. This is what I have tried to do in this chapter referring to the Greek populism of the '80s and the '90s. Much recent research is being directed to the understanding of contemporary Greek populism conveyed mostly by the leftist SYRIZA party, espousing more nuanced theoretical and methodological approaches which start to recognize the need for the emotions to be taken into account (De Cleen and Stavrakakis 2017; Brubaker 2019). Since a good many scholars agree that there is a paucity of research on the demand side of populist phenomena, a lot remains to be done as to the specification of their emotive underpinnings.

\section{Synopsis}

Focusing on the demand-side of the populist phenomenon, and continuing from the previous chapter, this chapter has shed more light on the emotional underpinning of populist orientations and politics in relation to nostalgia, anger, fear, efficacy, resentment and ressentiment. I have kept a distance from the mainstream ideational approach by defining populism as a cognitive-emotional schema consisting of two principal slots through which individuals orient themselves towards the political field: the 'people', and the division of society between two main power blocs. Special emphasis was given to the post-authoritarian Greek populism of the $1980 \mathrm{~s}$, interpreted as a case of ressentiment-ful politics. The thrust of the chapter's argument is that there has been a tipping point in the analysis of populism(s) where structural and historical accounts are balanced by bringing emotions in so that more nuanced explanations are possible.

\section{Notes}

1 Although there are certain links between them, political populism is not to be conflated with cultural populism which is an intellectual assumption, promoted mostly by cultural studies scholars, that the symbolic experiences and practices of ordinary people are more important analytically and politically than high-brow culture. On this premise, advocates of cultural populism - post-modernists or otherwise - have become sentimental in their solidarity with ordinary people, losing sight of the critical stance against commercialization of popular culture products and practices. If anything, this drift is due to the misrecognition that 'ordinary people' is an intellectual category and not an unmediated 
depiction of an authentic people's identity (McGuigan 1992). Pierre Ostiguy attempted an interesting link between cultural and political populism by introducing a 'high - low' socio-cultural division crossing the left-right dimension of political space. In this way, he takes into account the affectivity of populist narratives, defining populism as 'the antagonistic mobilizational flaunting of the "low" (Ostiguy 2017: 84).

2 Influenced by the notion of populist Zeitgeist as described by Mudde (2004), Tarchi (2016) construes populism as a ubiquitous phenomenon in today's representation politics and defines it as a distinctive mentality, as a specific forma mentis, connected to a vision of the social order based on a belief in the innate virtues of the people whose primacy is viewed as the source of legitimacy of governmental activity and of any other political action whatsoever.

3 Rightly arguing against the ideational definition of populism, by promoting their discursive approach which, in their account, allows for more thoroughly taking into consideration populism's crucial strategic dimensions as well as its material, performative and affective dimensions and investments, De Cleen and Stavrakakis (2017) are actually calling for a linking of their approach to that of the (political) sociology of emotions. The likelihood is that the discursive analysis of particular populisms would be enhanced by the analysis of particular emotions.

4 Given this emotional climate, the narrator in Mourselas' novel comments on the political marginalization: 'If anyone squealed on me, if any stool pigeon noticed me, I was a goner. I'm on the blacklist ...' (Mourselas 1996: 53).

5 Mourselas' novel was an editorial success with 200,000 sales during 1990-2007, something unusual for the Greek book market. As already mentioned, it was translated into English in 1996. In 1992-1993 it was transcribed into a 37-episode drama series by a private TV channel with unprecedented success. This also appeared on Australian television in 1995 and 1996 with English subtitles.

6 Critical historiography in Greece has repudiated public history's retroactive myth of an alleged massive resistance against the military regime, a myth congruent with the self-idealization of Greeks as a nation in perpetual resistance against all sorts of powers. The fact is that many offered their consent and many more tolerated the Junta, while the majority remained passive bystanders. Only a small minority of leftist, Centre-left and Centre-right groups and individuals took active initiatives to overthrow the military government.

7 In the sense of a non-lucrative third sector located inbetween the state and the market, pursuing public good and public service goals.

8 '(A)lthough they were different persons with different inclinations, the others were not supposed to move any further than we were standing or doing', Ioannou (1984: 102) recalls. 
a crucial political technology in late modern societies; in this respect the political sociology of emotions is normatively concerned with the distinction between democratic emotionality and demagogic emotional manipulation, an issue raised, among others, by the dynamics and ambivalences of what is called 'monitory democracy' (Keane 2009) at national and supranational level. As was indicated in the previous chapters, the political sociology of emotions rests at the middlerange of analysis just to keep at bay either abstracted empiricism or microfoundational reductions in its overall attempt to investigate the emotional bases of politics.

\section{Note}

1 Emotions are not founded in the bodies of oneself or other; they relationally emerge between interacting embodied, speaking and desiring subjects. As eloquently put by Ian Burkitt (2002: 159), it is as mistaken to look for our emotion in the body as it is to look for time inside a clock. 


\section{References}

Aarelaid-Tart, A. (2006). Cultural Trauma and Life Stories. Kikimora Publications A 15. Vaajakoski: Gummerus Printing.

Abbott, A. D. (2001). Chaos of Disciplines. Chicago and London: The University of Chicago Press.

Adorno, T. W. (1997). Theorie der Halbbildung. In Adorno, T. W. Gesammelte Schriften 8: 93-121. Frankfurt/M.: Suhrkamp.

Aeschbach, S. (2017). Ressentiment: An anatomy. Universite Genève no. L. 909.

Aguilar, P. (1996). Memoria y Olvido de la Guerra Civil Espanola. Madrid: Alianza Editorial.

Ahmed, S. (2004). The Cultural Politics of Emotion. Edinburgh: Edinburgh University Press.

Akkerman, A., Mudde, C., and Zaslove, A. (2014). How Populist Are the People? Measuring Populist Attitudes in Voters. Comparative Political Studies, 47(9): 1324-1353. https://doi.org/10.1177/0010414013512600.

Alapuro, R. (2002). Coping with the Civil War of 1918 in Twenty-first Century Finland. In Christie, K. and Cribb, R. (Eds) Historical Injustice and Democratic Transition in Eastern Asia and Northern Europe: Ghosts at the Table of Democracy. (169-183). London: Curzon.

Alcorn, M. (2019). Trauma. In Stavrakakis, Y. (Ed.) Routledge Handbook of Psychoanalytic Political Theory. (174-186). London: Routledge.

Alexander, J. C. (2012). Trauma. A Social Theory. Cambridge: Polity Press.

Alexander, J. C. (2006). The Civil Sphere. Oxford: Oxford University Press.

Alexander, J. C. (2004a). Toward a Theory of Cultural Trauma. In. Alexander, C.J., Eyerman, R., Giesen, B., Smelser, J. N. and Sztompka, P. (Eds) Cultural Trauma and Collective Identity. (1-30). Berkeley: University of California Press.

Alexander, J. C. (2004b). On the social construction of moral universals: The 'Holocaust' from war crime to trauma drama. In J. C. Alexander et al. (Eds) Cultural Trauma and Collective Identity. (196-263). Berkeley: University of California Press.

Alexander, J. C. (2003). The Meanings of Social Life: A Cultural Sociology. New York: Oxford University Press.

Alexander, J. C. and Smith, P. (2002). The strong program in cultural theory. In J. H. Turner (Eds) Handbook of Sociological Theory. (135-150). New York: Kluwer Academic/ Plenum Publishers.

Alexander, J. C. and Smith, P. (1998). Cultural Sociology or Sociology of Culture: Towards a Strong Program. Sociologie et Sociétés, 30(1): 107-116 (special edition). 
Alexander, J. C. and Giesen, B. (1987). From Reduction to Linkage: The Long View of the Micro-Macro Link. In Alexander, J. C., Giesen, B., Münch, R., and Smelser, N. J. (Eds) The Micro-Macro Link. (1-44). Berkeley, Los Angeles, London: University of California Press.

Alexander, J. C., Ronald J., and Smith, P. (Eds) (2012). The Oxford Handbook of Cultural Sociology. Oxford: Oxford University Press.

Allardt, E. (2001). Political Sociology. International Encyclopedia of the Social \& Behavioral Sciences. (11701-11706). Amsterdam: Elsevier Science Ltd.

Almond, G. and Verba, S. (1963). The Civic Culture. Political Attitudes and Democracy in Five Nations. Boston: Little Brown and Company.

Améry, J. (1999). At the Mind's Limits: Contemplations by a Survivor on Auschwitz and its Realities. London: Granta Books.

Andén-Papadopoulus, K. (2003). The Trauma of Representation. Visual Culture, Photojournalism and the September 11 terrorist Attack. Nordicom Review, 24(2): 89-104.

Anderson, B. (1983). Imagined Communities. Reflections on the Origin and Spread of Nationalism. London: Verso.

Andreadis, I., Stavrakakis, Y., and Demertzis, N. (2016). New Indices for Right Wing Populism. In IPSA World Congress. Poznań. http://paperroom.ipsa.org/papers/paper_ 64103.pdf.

Anselmi, W. and Gouliamos, C. (1998). Elusive Margins - Consuming Media, Ethnicity and Culture. Toronto, Buffalo, Lancaster: Guernica Publications.

Anthonissen, C. (2009). Considering the violence of voicelessness: Censorship and selfcensorship related to the South African TRC process. In Wodak, R. and Auer-Borea, G. (Eds) Justice and Memory. Confronting Traumatic Pasts. An International Comparison. (97-122). Vienna: Passagen Verlag.

Antoniou, G. (2007). The Memory and Historiography of the Greek Civil War. PhD. European University Institute, Florence.

Apter, D. (1965). The Politics of Modernization. Chicago and London: University of Chicago Press.

Arbid, M. A. (1985). In Search of the Person. Philosophical Explorations in Cognitive Science. Amherst: The University of Massachusetts Press.

Arcel, L. T. (2014). Pogrom in the Soul. The Asia Minor Disaster Trauma in Three Generations. Athens: Kedros.

Arendt, H. (1973). On Revolution. Middlesex: Penguin Books.

Arendt, H. (1958). The Human Condition. Chicago: University of Chicago Press.

Aristotle (1992). On Rhetoric: A Theory of Civic Discourse (Transl. by George A. Kennedy). Oxford: Oxford University Press.

Assmann, A. (2009). From collective violence to a common future: Four models for dealing with a traumatic past. In Wodak, R. and Auer Borea, G. (Eds) Justice and Memory. Confronting Traumatic Pasts. An International Comparison. (31-48). Vienna: Passagen Verlag.

Averill, J. R. (1980). The emotions. In Staub, E. (Ed.) Personality: Basic Aspects and Current Research. (134-199). Englewood Cliffs: Prentice Hall.

Badiou, A. (2016). Notre Mal Vient de plus loin, Penser les Tueries du 13 Novembre. Paris: Librairie Arthème Fayard.

Baer, A. (2001). Consuming History and Memory Through Mass Media Products. European Journal of Cultural Studies, 4(4): 491-501.

Baier, A. (1980). Hume on Resentment. Hume Studies, 6(2): 133-149. 
Ball, D. W. (1964). Covert Political rebellion as Ressentiment. Social Forces, 43(1): 93-101.

Banfield, C. E. (1958). The Moral Basis of a Backward Society. Glencoe, IL: The Free Press.

Barbalet, J. (2009). Consciousness, Emotions, and Science. In D. Hopkins et al. (Eds) Theorizing Emotions: Sociological Explorations and Applications. (39-71). Berlin: Campus.

Barbalet, J. (2006). Emotions in Politics: From the Ballot to Suicide Terrorism. In Clarke, S., Hoggett, P., and Thompson, S. (Eds) Emotion, Politics and Society. (31-55). London: Palgrave.

Barbalet, J. (1998). Emotion, Social Theory, and Social Structure. A Macrosociological Approach. Cambridge: Cambridge University Press.

Barbalet, J. and Demertzis, N. (2013). Collective Fear and Societal Change. In Demertzis, N. (Ed.) Emotions in Politics. The Affect Dimension in Political Tension. (167-185). London: MacMillan/Palgrave.

Barker, E. (1927). National Character and the Factors in its Formation. New York/ London: Harper.

Barnes, S., Kaase, M. et al. (1979). Political Action. Mass Participation in Five Western Democracies. Beverly Hills: Sage Publications.

Bartmanski, D. and Eyerman, R. (2011). The Worst was the Silence: The Unfinished Drama of the Katyn Massacre. In Eyerman, R., Alexander, J. C. and Breese, E. (Eds) Narrating Trauma. On the Impact of Collective Suffering. (237-266). Colorado: Paradigm Publishers.

Basaran, T., Bigo, D., Guittet, E.-P., and Walker R. B. J. (2017). International Political Sociology. Transversal Lines. London and New York: Routledge.

Baudrillard, J. (1994). The Illusion of the End. (Transl. Chris Turner). Stanford, CA: Stanford University Press.

Baudrillard, J. (1983). In the Shadow of the Silent Majorities. New York: Semiotext(e).

Bauer, O. (1924). Die Nationalitätenfrage und die Sozialdemokratie (2nd edition). Vienna: Brand.

Bauman, Z. (2017). Retrotopia. Cambridge: Polity Press.

Bauman, Z. (2006). Liquid Fear. Cambridge: Polity Press.

Bauman, Z. (1999). In Search of Politics. Oxford: Polity Press.

Bauman, Z. (1993). Postmodern Ethics. Oxford: Blackwell.

Bauman, Z. (1992). Intimations of Postmodernity. London: Routledge.

Bauman, Z. (1989). Modernity and the Holocaust. Ithaca, NY: Cornell University Press.

Bauman, Z. (1982). Memories of Class. The Prehistory and After-life of Class. London: Routledge.

Beck, Ulrich (1992). Risk Society. Towards a New Modernity. London: Sage Publications.

Becker, P. (2009). What makes us Modern(s)? The Place of Emotions in Contemporary Society. In D. Hopkins et al. (Eds) Theorizing Emotions: Sociological Explorations and Applications. (195-219). Berlin: Campus.

Bellamy, J. E. (1997). Affective genealogies: Psychoanalysis, Postmodernism, and the "Jewish question" after Auschwitz. Lincoln: University of Nebraska Press.

Ben-Ze'ev, A. (2000). The Subtlety of Emotions. Cambridge, MA: MIT Press.

Bennett, L. (2003). News. The Politics of Illusion. New York: Longman (5th edition).

Benski T. (2011). Emotion maps of participation in protest: The case of women in black against the occupation, in Israel. Research in Social Movements, Conflict and Change, 31(1): 3-34. 
Benski, T. and Fisher, E. (2014). Introduction: Investigating Emotions and the Internet. In Benski, T. and Fisher, E. (Eds) Internet and Emotions. (1-14). New York: Routledge.

Benski, T. and Langman, L. (2013). The effects of affects: The place of emotions in the mobilizations of 2011. Current Sociology, 61(4): 525-540.

Berezin, M. (2002). Secure States: Towards a political sociology of emotions. In Barbalet, J. (Ed.) Emotions and Society. (33-52). Oxford: Blackwell Publishing/The Sociological Review.

Berezin, M. (2001). Emotions and Political Identity: Mobilizing Affection for the Polity. In Goodwin, J., Jasper, J. M. and Polletta, F. (Eds) Passionate Politics. Emotions and Social Movements. (83-97). Chicago: The University of Chicago Press.

Berger P. and Luckman T. (1967). The Social Construction of Reality. A Treatise in the Sociology of Knowledge. London: Penguin Press.

Bericat, E. (2016). The sociology of emotions: Four decades of progress. Current Sociology, 64(3): 491-513.

Betz, H.-G. (2002). Conditions Favoring the Success and Failure of Radical Right-Wing Populist Parties in Contemporary Democracies. In: Mény, Y. and Surel Y. (Eds) Democracies and the Populist Challenge. (197-213). Hampshire: Palgrave.

Betz, H-G. and Johnson, C. (2004). Against the current - stemming the tide: the nostalgic ideology of the contemporary radical populist right. Journal of Political Ideologies, 9(3): 311-327.

Bewes, T. (1997). Cynicism and Postmodernity. London: Verso.

Bhabha, H. (1991). Question of Survival: Nations and Psychic States. In Donald, J. (Ed.) Psychoanalysis and Cultural Theory. (89-103). London: Macmillan.

Birns, N. (2005). Ressentiment and Counter-Ressentiment: Nietzsche, Scheler, and the Reaction Against Equality. Nietzsche Circle. Available online at www.nietzschecircle. com/essayArchive1.html.

Bloechl, J. (2013). Forgiveness and its Limits. An Essay on Vladimir Jankélevitch. In Udoff, A. (Ed.) Vladimir Jankélévitch and the Question of Forgiveness. (97-110). New York: Lexington Books.

Bocock, R. (1993). Consumption. London: Routledge.

Boltanski, L. (1999). Distant Suffering. Morality, Media and Politics. Cambridge: Cambridge University Press.

Boraine, A. (2006). Truth and Reconciliation Commission in South Africa amnesty: The price of peace. In Elster, J. (Ed.) Retribution and Reparation in the Transition to Democracy. (299-316). Cambridge, U.K.: Cambridge University Press.

Borradori, G. (Ed.) (2004). Philosophy in a Time of Terror. Dialogues with Jürgen Habermas and Jacques Derrida. Chicago: University of Chicago Press.

Bottomore, T. (1979). Political Sociology. London: Hutchinson.

Bourdieu, P. (1977). Outline of a Theory of Practice. Cambridge: Cambridge University Press.

Boym, S. (2002). Future of Nostalgia. London: Basic.

Bozatzis, N. (2014). Banal Occidentalism. In Antaki, C. and Condor, S. (Eds) Rhetoric, Ideology and Social Psychology. Essays in Honour of Michael Billig. (157-176). London and New York: Routledge.

Brandes, G. M. C. (1972). Friedrich Nietzsche. Haskell House Publishers.

Breakwell, G. (2007). The Psychology of Risk. Cambridge: Cambridge University Press.

Breese, B. E. (2013). Claiming Trauma through Social Performance: The Case of Waiting for Godot. In Eyerman, R., Alexander, J. C. and Breese, E. (Eds) Narrating Trauma. On the Impact of Collective Suffering. (213-236). Colorado: Paradigm Publishers. 
Breuilly, J. (1985). Nationalism and the State. Manchester: Manchester University Press.

Brighi, E. (2016). The Globalisation of Resentment: Failure, Denial, and Violence in World Politics. Millennium: Journal of International Studies, 44(3): 411-432.

Brooks, L. R. (Ed.) (1999). When Sorry isn't Enough. The Controversy over Apologies and Reparations for Human Injustice. New York \& London: New York University Press.

Brown, W. (1995). States of Injury: Power and Freedom in Late Modernity. Princeton, NJ: Princeton University Press.

Brubaker, R. (2019). Populism and nationalism. Nations and Nationalism, 25(3): 1-23. DOI: $10.1111 /$ nana.12522.

Brubaker, R. (2017). Why Populism? Theory and Society, 46: 357-385.

Brubaker, R. (1996). Nationalism Reframed: Nationhood and the National Question in the New Europe. Cambridge: Cambridge University Press.

Bruckner, P. (2010). The Tyranny of Guilt. An Essay on Western Masochism. Princeton: Princeton University Press.

Bruckner, P. (2000). The Temptation of Innocence. Living in the Age of Entitlement. New York: Algora Publishing.

Brudholm, Th. (2010). Hatred as an Attitude. Philosophical Papers, 39(3): 289-313. DOI: $10.1080 / 05568641.2010 .538912$.

Brudholm, T. (2008). Resentment's Virtue: Jean Améry and the Refusal to Forgive. Philadelphia: Temple University Press.

Burke, E. (1995). Reflections on the Revolution in France. In Dahbour, O. and Ishay, M. R. (Eds) The Nationalism Reader. (134-142). New Jersey: Humanities Press.

Burke, J. (2005). Fear: A Cultural History. London: Virago.

Burkitt, I. (2012). Emotional Reflexivity: Feeling, Emotion and Imagination in Reflexive Dialogues. Sociology, 46(3): 458-472.

Burkitt, I. (2002). Complex emotion: relations, feelings and images in emotional experience. In Barbalet, J. (Ed.) Emotions and Sociology. (151-167). Oxford: Blackwell.

Butler, J. (1827). Fifteen Sermons Preached at the Rolls Chapel. http://anglicanhistory. org/butler/rolls/.

Campbell, J. K. (1983). Traditional Values and Continuities in Greek Society. In Clogg, R. (Ed.) Greece in the 1980s. London: MacMillan.

Campbell, J. K. (1964). Honour, Family, and Patronage. New York and Oxford: Oxford University Press.

Campbell, K. (2004). The Trauma of Justice: Sexual Violence, Crimes Against Humanity and the International Criminal Tribunal for the Former Yugoslavia. Social Legal Studies, 13(3): 329-350. DOI: 10.1177/0964663904044998.

Camus, A. (1991). The Rebel. An Essay on Man in Revolt (transl. Anthony Bower). New York: Vintage Books.

Canovan, M. (1999). Trust the People! Populism and the Two Faces of Democracy. Political Studies, XLVII: 2-16.

Capelos, T. and Chrona, S. (2018). The Map to the Heart: An Analysis of Political Affectivity in Turkey. Politics and Governance, 6(4): 144-158.

Capelos, T. and Demertzis, N. (2018). Political Action and Resentful Affectivity in Critical Times. Humanity \& Society 1-24. DOI: 10.1177/0160597618802517.

Capelos, T., Katsanidou, A. and Demertzis, N. (2017). Back to Black: Values, Ideology and the Black Box of Political Radicalization. Science and Society 35: 35-68.

Cappella, J. and Jamieson, H. K. (1997). Spiral of Cynicism. The Press and the Public Good. New York and Oxford: Oxford University Press. 
Carpentier, N. (Ed.) (2007). Culture, Trauma, and Conflict. Cultural Studies Perspectives on War. Newcastle: Cambridge Scholars Publishing.

Caruth, C. (1995a). Introduction. In Caruth, C. (Ed.) Trauma: Explorations in Memory. (3-12). Baltimore: Johns Hopkins University Press.

Caruth, C. (1995b). Introduction. In Caruth, C. (Ed.) Trauma: Explorations in Memory. (151-156). Baltimore: Johns Hopkins University Press.

Castanho Silva, B., Andreadis, I., Anduiza, E., Blanuša, N., Corti, Y. M., Delfino, G., Rico, G., Ruth, S. Spruyt, B., Steenbergen, M., Littvay, L. (2019). Public Opinion Surveys: A New Scale. In Hawkins, K., Carlin, R., Littvay, L. and Rovira Kaltwasser, C. (Eds) The Ideational Approach to Populism: Concept, Theory, and Analysis. (150-177). Democracy and Extremism Series. London: Routledge.

Castoriadis, C. (1987). The Imaginary Institution of Society. Cambridge: Polity Press.

Chambers English Dictionary. (1990). Catherine Schwarz (Ed.). London: Chambers Harrap Publishers Ltd.

Charalambis, D. (1989). Clientelism and Populism. The Extra-institutional Consensus in the Greek Political System. Athens: Exandas Publications.

Charalambis, D. and Demertzis, N. (1993). Politics and Citizenship in Greece: Cultural and Structural Facets. Journal of Modern Greek Studies, 11(2): 219-40.

Charitopoulos, D. (2012). Aris. The Lord of Mountains. Athens: Topos Publications.

Chouliaraki, L. (2010). Journalism and the Visual Politics of War and Conflict. In Allan, S. (Ed.) The Routledge Companion to News and Journalism. (520-532). London and New York: Routledge.

Chouliaraki, L. (2006). The Spectatorship of Suffering. London: Sage Publications.

Chouliaraki, L. (2004). Watching 11 September: The Politics of Pity. Discourse and Society, 15(2-3): 185-98.

Clarke, S. (2004). The Concept of Envy: Primitive Drives, Social Encounters and Ressentiment. Psychoanalysis, Culture \& Society, 9(1): 105-117.

Clarke, S., Hoggett, P., and Thompson, S. (Eds) (2006). Emotion, Politics and Society. London: Palgrave/Macmillan.

Clogg, R. (1997). A Concise History of Greece. Cambridge: Cambridge University Press.

Clogg, R. (Ed.) (1993). Greece, 1981-89. The Populist Decade. New York: St. Martin's Press.

Clogg, R. (1979). A Short History of Modern Greece. Cambridge: Cambridge University Press.

Close, D. (1995). The Origins of the Greek Civil War. Longman Publishing Group.

Clough, P. T. and Halley, J. (Eds.) (2007). The Affective Turn. Theorizing the Social. Durham and London: Duke University Press.

Cohen, S. (2001). States of Denial: Knowing about Atrocities and Suffering, New York: John Wiley \& Sons.

Cooley, H. C. (1964). Human Nature and the Social Order. New York: Schocken Books.

Coonfield, G. (2007). News Images as Lived Images: Witness, Performance, and the U.S. Flag After 9/11. In Carpentier, N. (Ed.) Culture, Trauma, and Conflict. Cultural Studies Perspectives on War. (163-181). Newcastle: Cambridge Scholars Publishing.

Concise Oxford Dictionary of Current English. (1990). R. E. Allen (Ed.). Oxford: Clarendon Press.

Connerton, P. (1989). How Societies Remember. Cambridge: Cambridge University Press.

Connolly, W. (1991). Identity/Difference: Democratic Negotiations of Political Paradox. Ithaca, NY: Cornell University Press. 
Coser, A. L. (1961). Max Scheler: An Introduction. In Scheler, M. Ressentiment. (5-32). Glencoe: Free Press.

Cossarini, P. and Vallespín, F. (2019). Introduction: Populism, Democracy, and the Logic of Passion. In Cossarini, P. and Vallespín, F. (Eds) Populism and Passions. Democratic Legitimacy after Austerity. (1-12). New York: Routledge.

Cowen, T. (2006). How far back should we go? Why restitution should be small. In J. Elster (Ed.) Retribution and Reparation in the Transition to Democracy. (17-32). Cambridge, U.K.: Cambridge University Press.

Cramer, K. J. (2016). The Politics of Resentment: Rural Consciousness in Wisconsin and the Rise of Scott Walker. Chicago and London: The University of Chicago Press.

Crook S., Pakulski J., and Waters M. (1992). Postmodernization. Change in Advanced Society. London: Sage Publications.

Cunningham, M. (2012). The apology in politics. In Thompson, S. and Hoggett, P. (Eds) Politics and the Emotions: The Affective Turn in Contemporary Political Studies. (139-155). New York: Continuum International Publishing Group.

Dalton, R. (1988). Citizen Politics in Western Democracies. Chatham/New Jersey: Chatham House Publishers, Inc.

Damasio, A. R. (1999). The Feeling of What Happens. Body and Emotion in the Making of Consciousness. New York: Harcourt Brace \& Company.

Danto, A. C. (1985). Narration and Knowledge: Including the Integral Text of Analytical Philosophy of History. New York: Columbia University Press.

Davies, J. C. (1962). Toward a Theory of Revolution. Source: American Sociological Review, 27(1): 5-19.

Davis, A. (1988). An Autobiography. New York: International Publishers.

Davou, B. (2000). Thought Processes in the Information Age. Issues of Cognitive Psychology and Communication. Athens: Papazissis Publications.

Davou, B. and Demertzis, N. (2013). Feeling the Greek financial crisis. In Demertzis, N. (Ed.) Emotions in Politics. The Affect Dimension in Political Tension. (93-123). Palgrave/MacMillan, London.

Dayan, D. (2007). On Morality, Distance and the Other. Roger Silverstone's Media and Morality. International Journal of Communication, 1: 113-122.

de Balzac, H. (2004). Lost Illusions. Project Gutenberg EBook. [\#13159].

De Cleen, B. and Stavrakakis, Y. (2017). Distinctions and Articulations: A Discourse Theoretical Framework for the Study of Populism and Nationalism. Javnost - The Public. DOI: 10.1080/13183222.2017.1330083.

De la Mora, F. G. (1987). Egalitarian Envy: The Political Foundations of Social Justice. New York: Paragon Publishers House.

de Rivera, J. (1992). Emotional Climate: Social Structure and Emotional Dynamics. In K. T. Strongman (Ed.) International Review of Studies on Emotion, vol. 2. (197-218). New York: John Wiley \& Sons.

Dearing, J. W. and Rogers, E. M. (1996). Agenda-Setting. London: Sage Publications.

Deegan-Krause, K. (2007). New Dimensions on Political Cleavage. In Dalton, R. J. and Klingemann, H.-D. (Eds) The Oxford Handbook of Political Behavior. (538-556). Oxford and New York: Oxford University Press.

Degli, E. F. (2015). War as Social Regeneration: Sombart from The Quintessence of Capitalism to Merchants and Heroes. In Antonio L. Palmisano (Ed.) Sombart's Thought Revisited. DADA. Rivista di Antropologia Post-globale, 1: 41-53. 
Dekker, P. (2005). Political Cynicism: A Hard Feeling or an Easy Way to Maintain Distance? Paper presented in the Political Psychology Section at the ECPR, Budapest 8-11 September.

Demertzis, N. (2017). Forgiveness and Ressentiment in the Age of Traumas. Oxford Research Encyclopedia, Politics, Oxford University Press, USA. DOI: 10.1093/ acrefore/9780190228637.013.146.

Demertzis, N. (2014). Political Emotions. In Nesbitt-Larking, P., Kinvall, C. and Capelos, T. (Eds) The Palgrave Handbook of Global Political Psychology. (223-241). London: Palgrave/Macmillan.

Demertzis, N. (2013). Introduction: Theorizing the Emotions-Politics Nexus. Demertzis, N. (Ed.) Emotions in Politics. The Affect Dimension in Political Tension. (1-16). London: Palgrave/MacMillan.

Demertzis, N. (2009). Mediatizing traumas in the risk society: A sociology of emotions approach. In Hopkins, D., Kleres, J., Flam, H., and Kuzmics, H. (Eds) Theorizing Emotions: Sociological Explorations and Applications. (143-168). Frankfurt: Campus Verlag.

Demertzis, N. (2006). Emotions and Populism. In Clarke, S., Hoggett, P., and Thompson, S. (Eds) Emotion, Politics and Society. (103-122). London: Palgrave.

Demertzis, N. (2004). Populism and Ressentiment. A Contribution of the (political) Sociology of Emotions. Science and Society, 12: 75-114. DOI: http://dx.doi.org/10.12681/sas.768.

Demertzis, N. (1997). Greece. In Eatwell, R. (Ed.) European Political Culture. (107-121). London: Routledge.

Demertzis, N. (1996a). The Nationalist Discourse. Ambivalent Semantic Field and Contemporary Tendencies. Athens: Ant. N. Sakkoulas

Demertzis, N. (1996b). La place de la religion dans la culture politique grecque. In Mappa, S. (Ed.) Puissance et Impuissance de l'État. (223-244). Paris: Karthala.

Demertzis, N. (1985). Cultural Theory and Political Culture. New Directions and Proposals. Lund: Studentlitteratur.

Demertzis, N. and Lipowatz, T. (2006). Envy and Ressentiment. Passions of the Soul and the Closed Society. Athens: Polis (in Greek).

Demertzis, N., Papathanassopoulos, S., and Armenakis, A. (1999). Media and Nationalism. The Macedonian Question. Harvard International Journal of Press/Politics, 44(3): 26-50. https://doi.org/10.1177/1081180X99004003004.

Demertzis, N. and Stratoudaki, H. (2020). Greek Nationalism as a Case of Political Religion: Rituals and Sentimentality. Historical Social Research, 45(1): 103-128. DOI: 10.12759/hsr.45.2020.1.103-128.

Demertzis, N. and Tsekeris, C. (2018). Multifaceted European Public Sphere. SocioCultural Dynamics. London: Media@LSE Working Paper Series.

Derrida, J. (2003). On Cosmopolitanism and Forgiveness. London: Routledge.

Derrida, J. (1986). Foreword: Fors: The Anglish Words of Nicolas Abraham and Maria Torok. In Abraham, N. and Torok, M. The Wolf Man's Magic Word. A Cryptonymy. (xi-xlviii). Minneapolis: University of Minnesota Press.

Deutsch, K. W. (1969). Nationalism and its Alternatives. New York: Knopf/Random House.

Deutsch, K. W. (1953). Nationalism and Social Communication: An Inquiry into the Foundations of Nationality. Massachusetts: The M.I.T. Press (2nd edition 1966).

Diamandouros, N. (1994). Cultural Dualism and Political Change in Postauthoritarian Greece. Centro de Estudios Avanzados en Ciencias Sociales (CEACS). 
Diamandouros, N. (1983). Greek political culture in transition: Historical origins, evolution, current trends. In Clogg, R. (Ed.) Greece in the 1980s. (43-69). London: The Macmillan Press.

Diamond, L. (2015). Facing Up to the Democratic Recession. Journal of Democracy, 26 (1): 141-55.

Diefenbach, A., Kahl, A. et al. (2019). The Politics of Affective Societies: An Interdisciplinary Essay (EmotionsKulturen/EmotionCultures). Bielefeld: Transcript-Verlag.

Dijk, van W. W. and Ouwerkerk, J. W. (Eds) (2014). Schadenfreude. Understanding Pleasure at the Misfortune of Others. Cambridge: Cambridge University Press.

Dostoyevsky, F. (1864/2000). Notes from the Underground. Athens: Govostis Publications.

Döveling, K. (2009). Mediated Parasocial Emotions and Community: How Media May Strengthen or Weaken Social Communities. In Hopkins, D., Kleres, J., Flam, H., and Kuzmics, H. (Eds) Theorizing Emotions: Sociological Explorations and Applications. (315-337). Berlin: Campus.

Döveling, K., von Scheve, Ch., and Konijn, E. A. (2011) (Eds) The Routledge Handbook of Emotions and Mass Media. London: Routledge.

Dufourmantelle, A. and Derrida, J. (2000). Of Hospitality. Anne Dufourmantelle invites Jacques Derrida to respond (translated by Rachel Bowlby). Stanford: Stanford University Press.

Edelstein, A. (1997). Total Propaganda. From Mass Culture to Popular Culture. London: Lawrence Erlbaum.

Edkins, J. (2003). Trauma and the Memory Politics. Cambridge: Cambridge University Press.

Eisenberg, N. (2004). Empathy and Sympathy. In Lewis, M. and Haviland-Jones, J. M. (Eds) Handbook of Emotions (2nd paperback edition). (677-691). New York/London: The Guilford Press.

Eisenstadt, S. N. (2013). Comparative Civilizations and Multiple Modernities. Leiden and Boston: Brill.

Eisenstadt, S. N. (1973). Tradition, Change, and Modernity. New York: John Wiley.

Ekman, P. (1993). Facial Expression and Emotion. American Psychologist, 48: 384-392.

Eliasoph, N. (1998). Avoiding Politics. How Americans Produce Apathy in Everyday Life. Cambridge: Cambridge University Press.

Eliasoph, N. (1990). Political Culture and the Presentation of a Political Self: A Study of the Public Sphere in the Spirit of Erving Goffman. Theory and Society, 19 (4): 465-494.

Ellis, D. (1999). Research on Social Interaction and the Micro-Macro Issue. Research on Language and Social Interaction, 32(1/2): 31-40.

Elsaesser, T. (2014). German Cinema-Terror and Trauma: Cultural Memory since 1945. London: Routledge.

Elster, J. (2006). Retribution. In J. Elster (Ed.) Retribution and Reparation in the Transition to Democracy. (33-56). Cambridge, U.K.: Cambridge University Press.

Elster, J. (1999). Alchemies of the Mind. Rationality and the Emotions. Cambridge: Cambridge University Press.

Elster, J. (1989). Nuts and Bolts for the Social Sciences. Cambridge: Cambridge University Press.

Elytis, O. (1994). Open Papers - Selected Essays. Washington: Copper Canyon Press.

Entman, R. M. (1993). Framing. Toward Clarification of a Fractured Paradigm. Journal of Communication, 43(4): 51-58. 
Erikson, K. (1995). Notes on Trauma and Community. In Caruth, C. (Ed.) Trauma: Explorations in Memory. (183-199). Baltimore: Johns Hopkins.

Evans, D. (1996). An Introductory Dictionary of Lacanian Psychoanalysis. London: Routledge.

Eyerman, R. (2015). Is this America? Katrina as Cultural Trauma. The Katrina Bookshelf. Austin: University of Texas Press.

Eyerman, R. (2012/2017). Cultural Trauma: Emotion and Narration. In Alexander, J. C., Jacobs, R. N., and Smith, P. (Eds) The Oxford Handbook of Cultural Sociology. Oxford: Oxford University Press. Online Publication Date: Jun 2017. DOI: 10.1093/oxfordhb/ 9780195377767.013.21.

Eyerman, R. (2011a). The Cultural Sociology of Political Assassination. From MLK to Fortuyn and van Gogh. New York: Palgrave/Macmillan.

Eyerman, R. (2011b). Intellectuals and cultural trauma. European Journal of Social Theory, 14(4): 453-467.

Eyerman, R. (2008). The Assassination of Theo Van Gogh: From Social Drama to Cultural Trauma. Durham, NC: Duke University Press.

Eyerman, R. (2001). Cultural Trauma. Slavery and the Formation of African American Identity. Cambridge: Cambridge University Press.

Eyerman, R., Alexander, J. C., and Breese, E. (Eds) (2013). Narrating Trauma: On the Impact of Collective Suffering. Boulder, CO: Paradigm.

Eyerman, R., Madigan, T., and Ring, M. (2017). Cultural Trauma, Collective Memory and the Vietnam War. Croatian Political Science Review, 54(1-2): 11-31.

Fassin, D. and Rechtman, R. (2009). The Empire of Trauma. An Inquiry into the Condition of Victimhood. Oxford and Princeton: Princeton University Press.

Fearon, J. and Laitin, D. D. (2003). Ethnicity, Insurgency, and Civil War. American Political Science Review, 97(1): 75-90.

Ferrante, E. (2015). The Story of the Lost Child. New York: Europa Editions.

Ferrante, E. (2014). Those Who Leave and Those Who Stay. New York: Europa Editions.

Ferrante, E. (2013a). My Brilliant Friend. New York: Europa Editions.

Ferrante, E. (2013b). The Story of a New Name. New York: Europa Editions.

Ferro, M. (2010). Resentment in History. Cambridge: Polity Press.

Fichte, J.-G. (1995). Address to the German Nation. In Dahbour, O. and Ishay, M. R. (Eds). The Nationalism Reader. (62-70). New Jersey: Humanities Press.

Fieschi, C. (2004). Introduction. Journal of Political Ideologies, 9(3): 235-240.

Fieschi, C. and Heywood, P. (2004). Trust, cynicism and populist anti-politics. Journal of Political Ideologies, 9(3): 289-309.

Finkelstein, N. G. (2003). The Holocaust Industry. Reflections on the Exploitation of Jewish Suffering. New York: Verso (2nd edition).

Fiske, J. (1987). Television Culture. London: Methuen.

Flam, E. (2013). The transnational movement for Truth, Justice and Reconciliation as an emotional (rule) regime? Journal of Political Power, 6(3): 363-384.

Flam, H. (2005). Emotions' map. A research agenda. In Flam, H. and King, D. (Eds) Emotions and Social Movements. (19-40). London: Routledge.

Flam, H. and Kleres, J. (Eds) (2015). Methods of Exploring Emotions. London: Routledge.

Flam, H. and King, D. (Eds) (2005). Emotions and Social Movements. London: Routledge.

Fleischacker, S. (1991). Philosophy in Moral Practice: Kant and Adam Smith. KantStudien, 82(3). https://doi.org/10.1515/KANT.1991.82.3.249. 
Fleischer, H. (2008). Wars of Memory. World War II in Public History. Athens: Nefeli Publications.

Fleischer, H. (1986). Im Kreuzschatten der Maechte: Griechenland 1941-1944. (OkkupationKollaboration-Resistance). Frankfurt/Bern/New York: Peter Lang.

Freud, S. (2003). An Outline of Psychoanalysis. London: Penguin Books. [First published in 1940].

Freud, S. (1986). Moses and Monotheism: Three Essays. In The Origins of Religion, The Pelican Freud Library, vol. 13. London: Penguin Books. [First published in 1939].

Freud, S. (1949). Group Psychology and the Analysis of the Ego (translated by J. Strachey). London: The Hogarth Press (5th Impression).

Freud, S. (1930/2001). Civilization and its Discontents. In The Standard Edition of the Complete Psychological Works, Vol. XXI. London: Vintage, The Hogarth Press.

Freud, S. and Breuer, J. (1895/1956). Studies on Hysteria. Pelican Freud Library, Standard Edition. London: Penguin Books.

Friedman, J. R. and Strauss, C. (2018). Introduction: The Person in Politics and Culture. In Strauss, C. and Friedman, J. R. (Eds) Political Sentiments and Social Movements. The Person in Politics and Culture. (1-29). London: Palgrave/Macmillan.

Frijda, N. H. (2004a). The Psychologists' Point of View. In Lewis, M. and Haviland-Jones, J. M. (Eds) Handbook of Emotions. (59-74). New York, London: The Guilford Press (2nd edition).

Frijda, N. H. (2004b). Emotion and action. In Manstead, A., Fridja, N., and Fischer, A. (Eds) Feelings and Emotions: The Amsterdam Symposium. (158-173). Cambridge: Cambridge University Press.

Frings, M. (2005). Max Scheler and the Psychopathology of the Terrorist. Modern Age, 47(3): 210-219.

Fritsche, J. (1999). Historical Destiny and National Socialism in Heidegger's Being and Time. Berkeley: University of California Press.

Fukuyama, F. (2018). Identity. Contemporary Identity Politics and the Struggle for Recognition. New York: Farrar, Straus and Giroux.

Furedi, F. (2004). Therapy Culture. Cultivating Vulnerability in an Uncertain Age. London: Routledge.

Gadamer, H.-G. (1979). Truth and Method. London: Sheed and Ward.

Gamson, W. A. (1992). Talking Politics. Cambridge: Cambridge University Press.

Gao, R. (2013). Revolutionary Trauma and Representation of the War: The Case of China in Mao's Era. In Eyerman, R., Alexander, J. C., and Breese, E. (Eds) Narrating Trauma. On the Impact of Collective Suffering. (81-105). Boulder \& London: Paradigm Publications. Gaulejac, V. De (1987). La Névrose de Classe. Paris: Hommes et groups.

Gavrilidis, A. (2008). Two brotherless peoples: On the Constitutive Traumas of Class Struggle. Psychoanalysis, Culture \& Society, 13: 143-162. DOI: 10.1057/pcs.2008.2.

Geertz, C. (1973). The Interpretation of Cultures. New York: Basic Books.

Gellner, E. (1994). Encounters with Nationalism. Oxford: Blackwell.

Gellner E. (1983). Nations and Nationalism. Oxford: Basil Blackwell.

Gellner, E. (1965). Thought and Change. London: Weidenfeld and Nicolson.

Gibbins, J. R. (1990). Contemporary Political Culture: An Introduction. In Gibbins, J. R. (Ed.) Contemporary Political Culture. Politics in a Postmodern Age. (1-30). London: Sage Publications.

Giddens, A. (1994). Beyond Left and Right. The Future of Radical Politics. Oxford: Polity Press. 
Giddens, A. (1992). The Transformation of Intimacy. Sexuality, Love \& Eroticism in Modern Societies. Stanford: Stanford University Press.

Giddens, A. (1990). The Consequences of Modernity. London: Polity Press.

Giddens A. (1985). The Nation-State and Violence. Cambridge: Polity Press.

Giddens, A. (1984). The Constitution of Society. Cambridge: Polity Press.

Giddens, A. (1981a). The Class Structure of the Advanced Societies. London: Hutchinson (2nd edition).

Giddens A. (1981b). A Contemporary Critique of Historical Materialism. London: The MacMillan Press.

Giesen, B. (2004a). Triumph and Trauma. Boulder: Paradigm Press.

Giesen, B. (2004b). The Trauma of Perpetrators. The Holocaust as the Traumatic Reference of German National Identity. In Alexander, J. C. et al. (Eds) Cultural Trauma and Collective Identity. (112-154). Berkeley: University of California Press.

Girard, R. (2005). Violence and the Sacred. London and New York: Continuum.

Girardet, R. (1997). Myths and Political Mythologies. Iași: European Institute.

Girvin, B. (1990). Change and Continuity in Liberal Democratic Political Culture. In Gibbins, J. R. (Ed.) Contemporary Political Culture. Politics in a Postmodern Age. (31-51). London: Sage Publications.

Glassner, B. (1999). The Culture of Fear. Why Americans Are Afraid of the Wrong Things. New York: Basic Books.

Glynos, J. and Mondon, A. (2019). The Political Logic of Populist Hype: The Case of RightWing Populism's 'Meteoric Rise' and Its Relation to the Status Quo. In Cossarini, P. and Vallespín, F. (Eds) Populism and Passions. Democratic Legitimacy after Austerity. (82-101). New York: Routledge.

Goldfarb, J. (1991). The Cynical Society. The Culture of Politics and the Politics of Culture in American Life. Chicago: The University of Chicago Press.

Goodwin, J. (2005). Revolutions and Revolutionary Movements. In Janoski, T., Alford, R. R., Hicks, A. M., and Schwartz, A. M. (Eds) The Handbook of Political Sociology. States, Civil Societies, and Globalization. (404-422). Cambridge: Cambridge University Press.

Goodwin, J. and Jasper, J. M. (2006). Emotions and Social Movements. In Stets, J. E. and Turner, J. H. (Eds) Handbook of the Sociology of Emotions. (611-635). New York: Springer.

Goodwin, J., Jasper, J. M., and Polletta, F. (2004). Emotional Dimensions of Social Movements. In Snow, D., Soule, S. A., and Kriesi, H. (Eds) The Blackwell Companion to Social Movements. (413-432). Malden, MA: Blackwell Publishing Ltd.

Goodwin, J., Jasper, J. M. and Polletta, F. (Eds) (2001a). Passionate Politics. Emotions and Social Movements. Chicago: The University of Chicago Press.

Goodwin, J., Jasper, J. M. and Polletta, F. (2001b). Why Emotions Matter. In Goodwin, J., Jasper, J. M. and Polletta, F. (Eds) Passionate Politics. Emotions and Social Movements. (1-24). Chicago and London: The University of Chicago Press.

Gordon, S. (1990). Social Structural Affects on Emotions. In Kemper, T. (Ed.) Research Agendas in the Sociology of Emotions. (145-179). New York: State University of New York Press.

Gordon, S. (1981). The sociology of sentiments and emotion. In Rosenberg, M. and Turner, R. H. (Eds) Social Psychology: Sociological Perspectives. (551-575). New York: Basic Books.

Gould, D. B. (2010). On Affect and Protest. In Staiger, J., Cvetkovitch, A. and Reynolds, A. (Eds) Political Emotions. New Agendas in Communication. (18-44). New York, London: Routledge. 
Gouldner, A. (1976). The Dialectic of Ideology and Technology. New York: Seabury.

Gouldner, A. W. (1970). The Coming Crisis of Western Sociology. London: Heineman.

Gourgouris, S. (1996). Dream Nation: Enlightenment, Colonization and the Institution of Modern Greece. Stanford, CA: Stanford University Press.

Gramsci, A. (1971 mimeo). On Machiavelli. Athens.

Gransow, V. and Offe, C. (1982). Political Culture and Politics in the Social Democratic Government, Telos 53: 67-80.

Greco, M. and Stenner, P. (Eds) (2008). Emotions: A Social Science Reader. London, New York: Routledge.

Greene, J. D. (2013). Moral Tribes: Emotion, Reason, and the Gap between Us and Them. New York: Pelican Books.

Greenfeld, L. (2018). Revolutions. In Outhwaite, W. and Turner, S. P. (Eds) The Sage Handbook of Political Sociology. (vol. 2) (685-698). London: Sage Publications.

Greenfeld, L. (2001). The Spirit of Capitalism. Nationalism and Economic Growth. Cambridge: Harvard University Press.

Greenfeld, L. (1992). Nationalism. Five Roads to Modernity. Massachusetts: Harvard University Press.

Greenfeld, L. and Eastwood, L. (2005). Nationalism in Comparative Perspective. In Janoski, T., Alford, R. R., Hicks, A. M., and Schwartz, A. M. (Eds) The Handbook of Political Sociology. States, Civil Societies, and Globalization. (247-264). Cambridge: Cambridge University Press.

Griswold, C. (2007). Forgiveness: A Philosophical Exploration. New York: Cambridge University Press.

Guiso, L., Herrera, H., Morelli, M., and Sonno, T. (2017). The Spread of Populism in Western Countries. http://voxeu.org.

Guzzini, S. (2016). International political sociology, or: The social ontology and power politics of process. Danish Institute for International Studies, \#6.

Hackett, J. (2016). Ressentiment, Trump and His Supporters. www.philpercs.com/2016/03/ ressentiment-trump-and-his-supporters.html.

Haddad, W. (1977). Nationalism in the Ottoman Empire. In Haddad, W. W. and Ochesenwald, W. (Eds) Nationalism in a Non-National State. The Dissolution of the Ottoman Empire. (3-24). Columbus: Ohio State University Press.

Haidia, E. (2000). The Punishment of Collaborators in Northern Greece, 1945-1946. In Mazower, M. (Ed.) After the War Was Over. Reconstructing the Family, Nation, and State in Greece, 1943-1960. (42-61). Princeton and Oxford: Princeton University Press.

Haidt, J. (2013). The Righteous Mind. Why Good People are Divided by Politics and Religion. London: Penguin Books.

Halbwachs, M. (1992). On Collective Memory. Chicago and London: The University of Chicago Press.

Hall, S. (1980). Encoding/decoding. In Hall S., Hobson D., Lowe A., and Willis P. (Eds) Culture, Media, Language. (128-138). London: Hutchinson.

Halperin, E., Russell, A., Dweck, C., and Gross, J. (2011). Anger, Hatred, and the Quest for Peace: Anger Can Be Constructive in the Absence of Hatred. The Journal of Conflict Resolution, 55(2): 274-291. Retrieved from www.jstor.org/stable/23049702.

Hardin, R. (Ed.) (2004). Distrust. New York: Russell Sage Foundation.

Hardin, R. (1999). Do we want trust in government? In Warren, M. E. (Ed.) Democracy \& Trust. (22-41). Cambridge: Cambridge University Press. 
Hartman, G. H. (2003). Trauma within the limits of literature. European Journal of English Studies, 7(3): 257-274.

Harvey, D. (1989). The Condition of Postmodernity. Oxford: Blackwell.

Hawkins, K. A., Riding, S., and Mudde, C. (2012). Measuring populist attitudes. Political Concepts Committee on Concepts and Methods Working Paper Series, 55: 1-35.

Hayes, C. (1933). Essays on Nationalism. New York: Macmillan.

Heaney, G. J. (2019). Emotion as power: capital and strategy in the field of politics. Journal of Political Power. DOI: 10.1080/2158379X.2019.1618485.

Heaney, G. J. (2013a). Emotions and power: a bifocal prescription to cure theoretical myopia. Journal of Political Power, 6(3): 355-362.

Heaney, G. J. (2013b). Emotions and Nationalism: A Reappraisal. In Demertzis, N. (Ed.) Emotions in Politics. The Affect Dimension in Political Tension. (243-263). London, England: Palgrave Macmillan.

Heaney, G. J. and Flam, H. (Eds) (2015). Power and Emotion. New York: Routledge.

Hegel, G. W. F. (1975). Hegel's Logic (translated by William Wallace). Oxford: Oxford University Press.

Hegel, G. W. F. (1967). The Phenomenology of Mind. New York: Harper Torchbooks.

Heller, A. (1982). A Theory of History. London: Routledge Kegan Paul.

Heller A. and Fehér F. (1988). The Postmodern Political Condition. Oxford: Polity Press.

Hennessy, A. (1969). Latin America. In Ionescu, G. and Gellner, E. (Eds). Populism. Its Meanings and National Characteristics. (28-61). Hertfordshire: The Garden City Press.

Herman, J. (1992). Trauma and Recovery: The Aftermath of Violence from Domestic Abuse to Political Terror. New York: Basic Books.

Hertz, F. (1966). Nationality in History and Politics. A Psychology and Sociology of National Sentiment and Nationalism. London: Routledge \& Kegan Paul (5th edition). (1st edition 1944).

Herzfeld, M. (2005). Cultural Intimacy. Social Poetics of the Nation-State. New York: Routledge (2nd edition).

Herzfeld, M. (1995). Hellenism and Occidentalism: The permutations of performance in Greek bourgeois identity. In Carrier, J. G. (Ed.) Occidentalism: Images of the West. (218-233). Oxford: Berg.

Herzfeld, M. (1989). Anthropology Through the Looking-glass: Critical Ethnography in the Margins of Europe. Cambridge: Cambridge University Press.

Herzfeld, M. (1986). Ours Once More: Folklore, Ideology, and the Making of Modern Greece. New York: Pella Publishing Company.

Hicks, A. M., Janoski, T. and Schwartz, M. A. (2005). Introduction. Political Sociology in the New Millennium. In Janoski, T., Alford, R. R., Hicks, A. M. and Schwartz, A. M. (Eds) The Handbook of Political Sociology. States, Civil Societies, and Globalization. (1-30). Cambridge: Cambridge University Press.

Hobsbawm, E. (1992). Nations and Nationalism since 1780. Programme, Myth, Reality. Cambridge: Cambridge Univ. Press.

Hochschild, A. R. (2016). Strangers in their own Land. Anger and Mourning on the American Right. New York: The New Press.

Hochschild, A. R. (2009). Introduction: An Emotions Lens on the World. In Hopkins, D. et al. (Eds) Theorizing Emotions: Sociological Explorations and Applications. (29-37). Berlin: Campus.

Hochschild, A. R. (1979). Emotion work, feeling rules, and social structure. American Journal of Sociology, 85(3): 551-575. 
Hochschild, A. R. (1975). The sociology of feeling and emotion: Selected possibilities. In Millman, M. and Kanter, R. (Eds) Another Voice. (280-307). New York: Anchor.

Hoggett, P. (2018). Resentment as a Political Force: From Nietzsche to Trump. www. climatepsychologyalliance.org/explorations/papers/264-resentment-as-a-political-forcefrom-nietzche-to-trump.

Hoggett, P. (2006). Pity, Compassion, Solidarity. In Clarke, S. Hoggett, P., and Thompson, S. (Eds) Emotion, Politics and Society. (145-161). New York: Palgrave Macmillan.

Hoggett, P. and Thompson, S. (2012). Introduction. In Thompson, S. and Hoggett, P. (Eds) Politics and the Emotions. The Affective Turn in Contemporary Political Studies. (1-19). New York: Continuum.

Hoggett, P., Wilkinson, H., and Beedell, P. (2013). Fairness and the Politics of Resentment. Journal of Social Policy, 42(3): 567-585. DOI: 10.1017/S0047279413000056.

Höijer, B. (2003). The Discourse of Global Compassion and the Media. Nordicom Review, 24(2): 19-29.

Hokka, J. and Nelimarkka, M. (2019). Affective economy of national-populist images: Investigating national and transnational online networks through visual big data. New Media \& Society, 1-23. https://doi.org/10.1177/1461444819868686.

Holcombe, R. G. (2012). Crony Capitalism: By-Product of Big Government. Working Paper, Mercatus Center of George Mason University, \# 12-32.

Holmes, M. (2010). The Emotionalization of Reflexivity. Sociology, 44(1): 139-154.

Homer, S. (2019). Greek Cinema in Times of Crisis: A Cultural Trauma in Becoming. (Unpublished paper).

Hondros, J. (1983). Occupation and Resistance: The Greek Agony 1941-44. New York: Pella Publishing Company.

Hopkins, D., Kleres, J., Flam, H., and Kuzmics, H. (Eds) (2009). Theorizing Emotions: Sociological Explorations and Applications. Frankfurt: Campus Verlag.

Horton, R. (1982). Tradition and Modernity Revisited. In Hollis, M. and Lukes, S. (Eds) Rationality and Relativism. (201-260). Oxford: Basil Blackwell.

Horkheimer, M. and Adorno, T. (2002). Dialectic of Enlightenment. Stanford, CA: Stanford University Press.

Hughes, P. M. (2016). Forgiveness. The Stanford Encyclopedia of Philosophy (Winter 2016 Edition), Edward N. Zalta (Ed.). https://plato.stanford.edu/archives/win2016/ entries/forgiveness/.

Hume, D. (1748/2018). An Enquiry Concerning Human Understanding. Global Grey globalgreyebooks.com.

Hume, D. (1739/1969). A Treatise of Human Nature. Middlesex: Penguin Books.

Huntington, S. and Dominguez, J. (1975). Political Development. In Greenstein, F. and Polsby, N. (Eds) Handbook of Political Science (Vol. III) (1-114). Massachusetts: Addison-Wesley Pub. Co.

Husserl, E. (1978). The Origin of Geometry. In Luckmann, T. (Ed.) Phenomenology and Sociology. Selected Readings. (42-70). Middlesex: Penguin Books.

Hutchinson, E. (2016). Affective Communities in World Politics: Collective Emotions after Trauma. Cambridge, U.K.: Cambridge University Press.

Hutchinson, E. and Bleiker, R. (2008). Emotional Reconciliation: Reconstituting Identity and Community after Trauma. European Journal of Social Theory, 11(3): 385-403.

Iatrides, J. (2002). The International Context of the Greek Civil War. In Nikolakopoulos, E., Rigos, A., and Psallidas, G. (Eds) The Civil War. From Varkiza to Grammos. February 1945-August 1949. (31-50). Athens: Themelio. 
Illouz, E. (2007). Cold Intimacies: The Making of Emotional Capitalism. Cambridge: Polity Press.

Inglehart, F. R. (2018). Cultural Evolution, People's Motivations Are Changing, and Reshaping the World. Cambridge: Cambridge University Press.

Ioannou, G. (1984). The Metropolis of Refugees. Athens: Kedros Publications.

Israel, J. (1979). The Language of Dialectics and the Dialectics of Language. New York: Humanities Press.

James, W. (1931/1890). The Principles of Psychology, vol. 2. New York: Henry Holt.

Jankélévitch, V. (2005). Forgiveness. Chicago: University of Chicago Press.

Jankélévitch, V. (1996). Should We Pardon Them? Critical Inquiry, 22(3): 552-572.

Jankélévitch, V. (1987). L'Ironie. Paris: Flammarion.

Janoski, T., Alford, R. R., Hicks, A. M., and Schwartz, M. A. (Eds) (2005). The Handbook of Political Sociology: States, Civil Societies, and Globalization. Cambridge: Cambridge University Press.

Jasper, M. J. (2005). Culture, Knowledge, Politics. In Janoski, T., Alford, R. R., Hicks, A. M. and Schwartz, A. M. (Eds) The Handbook of Political Sociology. States, Civil Societies, and Globalization. (115-134). Cambridge: Cambridge University Press.

Johnson, W. M., and Davey, G. C. L. (1997). The Psychological Impact of Negative TV News Bulletins: The Catastrophizing of Person Worries. British Journal of Psychology, 88: 85-91.

Jonas, H. (1984). The Imperative of Responsibility: In Search of an Ethics for the Technological Age. Chicago: University of Chicago Press.

Kaindaneh, S. and Rigby, A. (2012). Peace-building in Sierra Leone: The emotional dimension. In Thompson, S. and Hoggett, P. (Eds), Politics and the Emotions: The Affective Turn in Contemporary Political Studies. (157-179). New York: Continuum International Publishing Group.

Kalyvas, A. and Katznelson, I. (2008). Liberal Beginnings. Making a Republic for the Moderns. Cambridge: Cambridge University Press.

Kalyvas, S. (2002). Forms, Dimensions and Practices of Violence in Civil War (1943-1949): An initial approach. In Nikolakopoulos, E., Rigos, A., and Psallidas, G. (Eds) The Civil War. From Varkiza to Grammos. February 1945-August 1949. (188-207). Athens: Themelio.

Kalyvas, S. (2000). Red Terror: Leftist Violence during the Occupation. In Mazower, M. (Ed.) After the War Was Over. Reconstructing the Family, Nation, and State in Greece, 1943-1960. (142-183). Princeton and Oxford: Princeton University Press.

Kalyvas, S. and Marantzidis, N. (2015). Civil War Passions. Athens: Metechmio.

Kansteiner, W. (2004). Genealogy of a category mistake: A critical intellectual history of the cultural trauma metaphor. Rethinking History, 8(2): 193-221.

Kaplan, A. (2005). Trauma Culture. The Politics of Terror and Loss in Media and Literature. New Brunswick: Rutgers UP.

Karapostolis, V. (1985). The Impenetrable Society. Athens: Polytropon Publications.

Karyotis, G. and Gerodimos, R. (Eds) (2015). The Politics of Extreme Austerity: Greece in the Eurozone Crisis. Basingstoke, New York: Palgrave Macmillan.

Keane, J. (2009). The Life and Death of Democracy. London: Simon and Schuster.

Kedourie, E. (1993). Nationalism. Oxford: Blackwell (4th edition).

Kemper, T. D. (2004). Social Models in the Explanation of Emotions. In Lewis, M. and Haviland-Jones, J. M. (Eds) Handbook of Emotions. (45-58). New York, London: The Guilford Press (2nd edition). 
Kemper, T. (1991). An Introduction to the Sociology of Emotions. In Strongman, K. (Ed.) International Review of Studies on Emotion. Vol. 1 (301-349). New York: John Wiley.

Kemper, T. (1990) (Ed.) Research Agendas in the Sociology of Emotions. New York: State University of New York Press.

Kenny, M. (2017). Back to the populist future? Understanding nostalgia in contemporary ideological discourse, Journal of Political Ideologies, 22(3): 256-273. DOI: 10.1080/1 3569317.2017.1346773.

Kierkegaard, S. (1940). The Present Age and of the Difference Between a Genius and an Apostle (translated by Alexander Dru). New York: Harper Torchbooks.

Kinder, D. R. (2007). Curmudgeonly Advice. Journal of Communication, 57: 155-162.

King, R. R. (1973). Minorities Under Communism. Nationalities as a Source of Tension among Balkan Communist States. Cambridge, MA: Harvard University Press.

Kinnvall, C. and Nesbitt-Larking, P. (2011). The Political Psychology of Globalization: Muslims in the West. Oxford and New York: Oxford University Press.

Kitromilides, P. (1990). 'Imagined Communities' and the Origins of the National Question in the Balkans". In Blinkhorn, M. and Veremis T. (Eds) Modern Greece: Nationalism and Nationality. (23-66). Athens: Sage \& ELIAMEP.

Kleres, J. (2009). Preface: Notes on the Sociology of Emotions in Europe. In Hopkins, D., Kleres, J., Flam, H., and Kuzmics, H. (Eds) Theorizing Emotions: Sociological Explorations and Applications. (7-27). Frankfurt: Campus Verlag.

Knauft, B. M. (2018). On the Political Genealogy of Trump after Foucault. Genealogy, 2(4): 2-18.

Koh, E. (2019). Cultural Work in Addressing Conflicts and Violence in Traumatized Communities. New England Journal of Public Policy, 31(1): 1-14.

Kohn, H. (1961). The Idea of Nationalism. A Study in its Origins and Background. (2nd edition). New York: The MacMillan Company.

Kolko, G. (1994). Century of War. Politics, Conflict, and Society since 1914. New York: The New Press.

Konstan, D. (2011). Before Forgiveness: Classical Antiquity, early Christianity and Beyond. New England Classical Journal, 38(2): 91-109.

Konstan, D. (2010). Before Forgiveness. The Origins of a Moral Idea. New York and Cambridge: Cambridge University Press.

Koulouri, C. (Ed.) (2002). Clio in the Balkans. The Politics of History Education. Thessaloniki: CDRSEE.

Koumandaraki, A. (2002). The Evolution of Greek National Identity. Studies in Ethnicity and Nationalism, 2(2): 39-53.

Kövecses, Z. (2000). The Concept of Anger: Universal or Culture Specific? Psychopathology, 33(4): 159-170.

Koziak, B. (2000). Retrieving Political Emotion: Thumos, Aristotle, and Gender. University Park: The Pennsylvania University Press.

Kyriakidou, M. (2017). Remembering Global Disasters and the Construction of Cosmopolitan Memory. Communication, Culture \& Critique, 10: 93-111.

Kyriakidou, M. (2015). Media witnessing: exploring the audience of distant suffering. Media, Culture \& Society, 37(2): 215-231.

Kyriakidou, M. (2014). Distant Suffering in Audience Memory: The Moral Hierarchy of Remembering. International Journal of Communication, 8: 1474-1494. 
Lacan, J. (1977a). Ecrits. A Selection. (translated by A. Sheridan). London: Tavistock/ Routledge.

Lacan, J. (1977b). The Four Fundamental Concepts of Psycho-Analysis. (translated by A. Sheridan). London: Penguin Books.

Laclau, E. and Mouffe, C. (1985). Hegemony and Socialist Strategy. London: Verso.

Lafleur, M. (2007). Life and Death in the Shadow of the A-Bomb: Sovereignty and Memory on the 60th Anniversary of Hiroshima and Nagasaki. In Carpentier, N. (Ed.) Culture, Trauma, and Conflict. Cultural Studies Perspectives on War. (209-228). Newcastle: Cambridge Scholars Publishing.

Lakoff, G. and Johnson, M. (1980). Metaphors We Live By. Chicago: University of Chicago Press.

Lamb, R. (1987). Objectless Emotions. Philosophy and Phenomenological Research, 48(1): 107-117.

Laplanche, J. and Pontalis, J.-B. (1988). The Language of Psychoanalysis (translated by Donald Nicholson-Smith). London: Karnak Books.

Laplanche J., and Pontalis, J.-B. (1986). Vocabulaire de la Psychanalyse. Athens: Kedros Publications.

Larocco, S. (2011). Forgiveness: A quiet assault on the malicious. In Karabin, G. and Wigura, K. (Eds) Forgiveness: Promise, Possibility \& Failure. (3-12). Oxford: InterDisciplinary Press.

Lašas, A. (2016). Shadow of Guilt: U.S.-Rwandese Relations after the 1994 Genocide. In Ariffin, Y., Coicaud, J.-M., and Popovski, V. (Eds) Emotions in International Politics. (254-276). New York: Cambridge University Press.

Lash, C. (1978). The Culture of Narcissism. American Life in An Age of Diminishing Expectations. New York: W.W. Norton \& Company Inc.

Lash, S. (1994). Reflexivity and its Doubles: Structure, Aesthetics, Community. In Beck, U., Giddens, A., and Lash, S. Reflexive Modernization. Politics, Tradition and Aesthetics in the Modern Social Order. (110-173). Cambridge: Polity Press.

Latif, M., Blee, K., DeMichele, M., and Simi, P. (2018). How Emotional Dynamics Maintain and Destroy White Supremacist Groups. Humanity \& Society, 42(4): 480-501.

Le Bon, G. (1918). The Psychology of Revolution (translated by Bernard Miall). Global Grey (globalgreyebooks.com).

Le Bon, G. (1912). La Révolution Française et la Psychologie des Révolutions. (http:// classiques.uqac.ca/classiques/le_bon_gustave/revolution_francaise/revolution_franc. html).

Leigh-Fermor, P. (1966). Roumeli: Travels in Northern Greece. London: John Murray.

Leiss, W., Kline, S., and Jhally, S. (1986). Social Communication in Advertising. Persons, Products, and Images of Well Being. Toronto: Methuen.

Lekas, P. (2005). The Greek War of Independence from the Perspective of Historical Sociology. The Historical Review, 2: 161-183.

León, R., Romer, C., Novara, J., and Quesada, E. (1988). "Una Scala Para Medir del Resentimiento". Revista Latinoamericana Psicologia, 20(3): 331-354.

Lev-Wiesel, R. (2007). Intergenerational Transmission of Trauma Across Three Generations. A Preliminary Study. Qualitative Social Work, 6(1): 75-94.

Levine, P. D. (2018). Dark Fantasy. Regressive Movements and the Search for Meaning in Politics. London: Karnac. 
Levy, D. and Sznaider, N. (2002). Memory Unbound. The Holocaust and the Formation of Cosmopolitan Memory. European Journal of Social Theory, 5(1): 87-106.

Lévy, P. (1995). Qu' est-ce que le virtuel? Paris: Éditions La Découverte.

Leys, R. (2000). Trauma: A Genealogy. Baltimore, MD: Johns Hopkins University Press.

Lilla, M. (2016). The Shipwrecked Mind. On Political Reaction. New York: New York Review of Books.

Lincoln, A. (1995). First Inaugural Address, March 1861. In Dahbour, O. and Ishay, M. R. (Eds) The Nationalism Reader. (286-291). New Jersey: Humanities Press.

Lipovetsky, G. (1992). Le Grepuscule du Devoir. Paris: Gallimard.

Lipowatz, Th. (2014). Die Trügerische Verführung und die Unheimliche Enthüllung des Bösen. Berlin: Weidler Buchverlag.

Lipset, S. M. (1960). Political Man: The Social Bases of Politics. London: Heinemann.

Lipset, S. M. and Rokkan, S. (Eds) (1967). Party Systems and Voter Alignments: CrossNational Perspectives. New York: The Free Press.

Listhaug, O. (1995). The Dynamics of Trust in Politicians. In Klingemann, H.-D. and Fuchs, D. (Eds) Citizens and the State. (261-297). Oxford: Oxford University Press.

Luckhurst, R. (2008). The Trauma Question. London: Routledge.

Luostarinen, H. (2002). Journalism and the Cultural Preconditions of War. In Kempf, W. and Luostarinen, H. (Eds) Journalism and the New World Order. Studying War and the Media, Vol. 2. (273-83). Gothenburg: NORDICOM, Gothenburg University.

Lyon, D. (1994). Postmodernity. London: Open University Press.

Lyotard, J.-F. (1984). The Postmodern Condition: A Report on Knowledge. Manchester: Manchester University Press.

Lyrintzis, C. (1993). PASOK in Power: From 'Change' to Disenchantment. In Clogg, R. (Ed.) (1993). Greece, 1981-89. The Populist Decade. (26-46). New York: St. Martin’s Press.

Lyrintzis, C. (1984). Political Parties in Post-Junta Greece: A case of 'bureaucratic clientelism? In Pridham, G. (Ed.) The New Mediterranean Democracies. Regime Transition in Spain, Greece and Portugal. (99-118). London: Frank Cass.

Magni, G. (2017). It's the emotions, Stupid! Anger about the economic crisis, low political efficacy, and support for populist parties. Electoral Studies, 50: 91-102.

Makrides, V. (1995). The Orthodox Church and the Post-War Religious Situation in Greece. In Roof, W., Carroll, J., and Roozen, D. (Eds) The Post-War Generation and Establishment Religion. Cross-Cultural Perspectives. (225-245). Oxford: Westview Press.

Maldonado, M. A. (2019). Political Affects in the Neuroscientific Age. In Cossarini, P. and Vallespín, F. (Eds) Populism and Passions. Democratic Legitimacy after Austerity. (15-30). New York: Routledge.

Mann, R. and Fenton, S. (2017). Nation, Class and Resentment. The Politics of National Identity in England, Scotland and Wales. London: Palgrave/MacMillan.

Mazzini, G. (1995). The Duties of Man. In Dahbour, O. and Ishay, M. R. (Eds) The Nationalism Reader. (87-97). New Jersey: Humanities Press.

Marantzides, N. (2002). Ethnic Dimensions of the Civil War. In Nikolakopoulos, E., Rigos, A., and Psallidas, G. (Eds) The Civil War. From Varkiza to Grammos. February 1945-August 1949. (208-221). Athens: Themelio.

Marantzides, N. and Antoniou, G. (2004). The Axis Occupation and Civil War: Changing Trends in Greek Historiography, 1941-2002. Journal of Peace Research, 41(2): 223-231. 
Marcus, G. E. (2002). The Sentimental Citizen. Emotion in Democratic Politics. University Park, PA: Pennsylvania State University Press.

Marcus, G. E., Neuman, R. W. and MacKuen, M. B. (2000). Affective Intelligence and Political Judgment. Chicago: University of Chicago Press.

Margarites, G. (1989). Internecine conflicts in Occupation (1941-1944): Analogies and differences. In Fleischer, H. and Svoronos, N. (Eds) Greece 1936-1944. Dictatorship, Occupation, Resistance. (505-515). Athens: Cultural Institute of the Agricultural Bank of Greece.

Martin, E. (2013). The Potentiality of Ethnography and the Limits of Affect Theory. Current Anthropology, 54: S149-S158.

Marx, K. (1844/1978). Critique to the Hegelian Philosophy of the State and Right. Athens: Papazissis.

Massumi, B. (2015). Politics of Affect. Cambridge: Polity Press.

Massumi, B. (2002). Parables for the Virtual; Movement, Affect, Sensation. Durham, NC: Duke University Press.

Massumi, B. (1995). The Autonomy of Affect. Cultural Critique, 31: 83-109.

Mateos, S. and Laiz, Á.-M. (2018). International Relations and Political Sociology. In Outhwaite, W. and Turner, S. P. (Eds) The Sage Handbook of Political Sociology. (Vol. 1) (172-188). London: Sage Publications.

Maurras, C. (1995). The Future of French Nationalism. In Dahbour, O. and Ishay, M. R. (Eds) The Nationalism Reader. (216-221). New Jersey: Humanities Press.

Mavrogordatos, G. (1983). Stillborn Republic. Social Coalitions and Party Strategies in Greece, 1922-1936. Berkeley: University of California Press.

Mazower, M. (2018). What You Did Not Tell. A Father's Past and a Journey Home. London: Penguin Books.

Mazower, M. (2000). Three Forms of Political Justice: Greece, 1944-1945. In Mazower, M. (Ed.) After the War Was Over. Reconstructing the Family, Nation, and State in Greece, 1943-1960. (24-41). Princeton and Oxford: Princeton University Press.

Mazower, M. (1993). Inside Hitler's Greece. New Haven: Yale University Press.

McGuigan, J. (1992). Cultural Populism. London: Routledge.

Mead, G. H. (1934). Mind, Self, and Society. From the Standpoint of a Social Behaviorist. Chicago, London: The University of Chicago Press.

Meek, A. (2010). Trauma and Media. Theories, Histories, and Images. New York: Routledge.

Meinecke, F. (1908). Weltbuergertum und Nationalstaat. Leipzing: Koehler \& Amelang.

Meltzer, B. and Musolf, G.-R. (2002). Resentment and Ressentiment. Sociological Inquiry. 72(2): 240-255.

Merton, R. (1957/1968). Social Theory and Social Structure. New York: The Free Press.

Meštrović, S. G. (1997). Postemotional Society. London: Sage Publications.

Milbrath, L. and Goel, M. (1977). Political Participation. New York: Univ. Press of America.

Milka, A. and Warfield, A. (2017). News Reporting and Emotions Part 2: Reporting Disaster: Emotions, Trauma and Media Ethics. https://historiesofemotion.com.

Miller, N. and Tougaw, J. (Eds) (2002). Extremities: Trauma, Testimony and Community. Urbana: University of Illinois Press.

Mills, C. W. (1959/2000). The Sociological Imagination (with a new Afterword by Todd Gitlin). New York: Oxford University Press.

Minkenberg, M. (2000). The Renewal of the Radical Right: Between Modernity and Antimodernity. Government and Opposition, 35: 170-188. DOI: 10.1111/1477-7053.00022. 
Minogue, K. (1969). Populism as a Political Movement. In Ionescu, G. and Gellner, E. (Eds) Populism. Its Meanings and National Characteristics. (197-211). Hertfordshire: The Garden City Press.

Minow, M. (1998). Between Vengeance and Forgiveness. Facing History after Genocide and Mass Violence. Boston: Beacon Press.

Mishra, P. (2017). Age of Anger: A History of the Present. New York: Farrar, Straus and Giroux.

Mitter, R. (2017). 80 years later: can China, Japan overcome Nanking Massacre's legacy? www.scmp.com/week-asia/opinion/article/2123261/80-years-later-can-china-japanovercome-nanking-massacres-legacy.

Moeller, S. D. (1999). Compassion Fatigue: How the Media Sell Disease, Famine, War and Death. New York and London: Routledge.

Moffitt, B. (2016). The Global Rise of Populism: Performance, Political Style, and Representation. Stanford, California: Stanford University Press.

Moore, B. (1984). Privacy. Studies in Social and Cultural History. New York: M.E. Sharpe, Inc.

Moore, B. (1978). Injustice. The Social Bases of Obedience and Revolt. New York: Macmillan.

Moruno, D. M. (2013). Introduction. On Resentment: Past and Present of an Emotion. In Fantini, B., Moruno, D. M. and Moscoso, J. (Eds) On Resentment: Past and Present. (1-18). Newcastle: Cambridge Scholars Publishing.

Moulier-Boutang, Y. (2012). Cognitive Capitalism. Cambridge: Polity Press.

Mounk, Y. (2018). The People vs. Democracy: Why our Freedom is in Danger and how to Save it. Cambridge, Massachusetts: Harvard University Press.

Mourselas, K. (1996). Red Dyed Hair (translated by Fred A. Reed). Athens: Kedros Publications.

Mouzelis, N. (2008). Modern and Postmodern Social Theorizing. Bridging the Divide. Cambridge: Cambridge University Press.

Mouzelis, N. (1995). Greece in the Twenty-first Century: Institutions and Political Culture. In Constas, D. and Stavrou, G. T. (Eds) Greece Prepares for the Twenty-first Century. (17-34). Baltimore and London: The John Hopkins University Press.

Mouzelis, N. (1986). Politics in the Semi-Periphery. Early Parliamentarism and Late Industrialism in the Balkans and Latin America. London: Macmillan.

Mouzelis, N. (1985). On the Concept of Populism: Populist and Clientelist Models of Incorporation in Semiperipheral Polities. Politics and Society, 14(3): 329-348.

Mudde, C. (2017). Populism. An Ideational Approach. In Kaltwasser, C. R., Taggart, P., Espejo, P. O., and Ostiguy, P. (Eds) The Oxford Handbook of Populism. (27-47). Oxford: Oxford University Press.

Mudde, C. (2015). SYRIZA. The Refutation of the Populist Pledge. Athens: Epikentro Publications.

Mudde, C. (2004). The populist Zeitgeist. Government and Opposition, 39(4): 542-563.

Mudde, C. and Rovira-Kaltwasser, R. C. (2017). Populism: A Very Short Introduction. Oxford: Oxford University Press.

Müller, J.-W. (2016). What is Populism? Philadelphia: University of Pennsylvania Press.

Murphy, G. J. (2005). Forgiveness, Self-Respect, and the Value of Resentment. In Worthington, L. E. (Ed.) Handbook of Forgiveness. (33-40). New York: Routledge.

Murphy, G. J. (1998). Forgiveness and Resentment. In Murphy, G. J. and Hampton, J. (Eds) Forgiveness and Mercy. (14-34). Cambridge: Cambridge University Press.

Mylonas, H. (2003). The Comparative Method and the Study of Civil Wars. Science and Society, 11: 1-35. DOI: http://dx.doi.org/10.12681/sas.915. 
Nabi, R. L. (2003). Exploring the Framing Effects of Emotion. Communication Research, 30(2): 224-247.

Nabi, R. L. (2002). Discrete emotions and persuasion. In Dillard, J. and Pfau, M. (Eds) Handbook of Persuasion. (289-308). Thousand Oaks, CA: Sage.

Nabi, R. L. (1999). A Cognitive-Functional Model for the Effects of Discrete Negative Emotions on Information Processing, Attitude Change, and Recall. Communication Theory, 9: 292-320.

Nabi, R. L., Jiyeon So, J., and Prestin, A. (2011). Media-based emotional coping. Examining the emotional benefits and pitfalls of media consumption. In Döveling, K., von Scheve, C. and Konijn, E. A. (Eds) The Routledge Handbook of Emotions and Mass Media. (116-132). London: Routledge.

Nadal, M. M. and Calvo, M. (Eds) (2014). Trauma in Contemporary Literature. Narrative and Representation. New York: Routledge.

Nash, K. (Ed.) (2000). Readings in Contemporary Political Sociology. Oxford: Blackwell Publishers.

Nash, K. and Scott, A. (Eds) (2001). The Blackwell Companion to Political Sociology. Oxford: Blackwell Publishing.

Natanson, M. (1978). Phenomenology as a Rigorous Science. In Luckmann, T. (Ed.) Phenomenology and Sociology. Selected Readings. (181-199). Middlesex: Penguin Books.

Neil, A. G. (1998). National Trauma and Collective Memory: Major Events in the American Century. New York: M. E. Sharpe.

Nesbitt-Larking, P., Kinnvall, C., Capelos, T., and Dekker, H. (Eds) (2014). The Palgrave Handbook of Global Political Psychology. London: Palgrave/Macmillan.

Nietzsche, F. (1895/2014). The Antichrist. Athens: Gutenberg.

Nietzsche, F. (1994/1887). On the Genealogy of Morality (translated by C. Deithe). Cambridge: Cambridge University Press.

Nobles, M. (2008). The Politics of Official Apologies. Cambridge, U.K.: Cambridge University Press.

Norris, P. and Inglehart, F. R. (2019). Cultural Backlash: Trump, Brexit, and the rise of Authoritarian-populism. New York: Cambridge University Press.

Novello, S. (2015). Max Scheler's ordo amoris in Albert Camus's philosophical work. Thaumazein, 3: 199-216.

Nussbaum, M. (2016). Anger and Forgiveness. Resentment, Generosity, Justice. Oxford: Oxford University Press.

Nussbaum, M. C. (2013). Political Emotions. Why Love Matters for Justice. Cambridge MA: The Belknap Press of Harvard University Press.

Nussbaum, M. C. (2006). Radical evil in the Lockean state: The neglect of the political emotions. Journal of Moral Philosophy, 3(2): 159-178.

Nussbaum, M. C. (2001). Upheavals of Thought. The Intelligence of Emotion. Cambridge: Cambridge University Press.

Offe. C. (1999). How can we trust our fellow citizens? In Warren, M. E. (Ed.) Democracy \& Trust. (42-87). Cambridge: Cambridge University Press.

Offe, C. (1985). New Social Movements: Challenging the Boundaries of Institutional Politics. Social Research, 52(4): 817-868.

O'Keefe, J. D. (2000). Guilt and Social Influence. In Roloff, M. E. (Ed.) Communication Yearbook 23. (67-101). London: Sage Publications.

Olick, J. (2007). The Politics of Regret: On Collective Memory and Historical Responsibility. New York: Routledge. 
Orum, A. M. and Dale, J. G. (2009). Introduction to Political Sociology. Power and Participation in the Modern World (5th Edition), New York and Oxford: Oxford University Press.

Ost, D. (2004). 'Politics as the Mobilization of Anger'. European Journal of Social Theory, 7(2): 229-244.

Ostiguy, P. (2017). Populism. A Socio-Cultural Approach. In Kaltwasser, C. R., Taggart, P., Espejo, P. O., and Ostiguy, P. (Eds) The Oxford Handbook of Populism. (73-97). Oxford: Oxford University Press.

Otto, L. P., Fabian, T., Maier, M., and Ottenstein, C. (2019). Only One Moment in Time? Investigating the Dynamic Relationship of Emotions and Attention Toward Political Information With Mobile Experience Sampling. Communication Research, 1-24. https://doi.org/10.1177/0093650219872392.

Outhwaite, W. and Turner, S. P. (Eds) (2018). The SAGE Handbook of Political Sociology. London: Sage Publications.

Oxford Advanced Learner's Dictionary of Current English (4th edition by A. P. Cowie, Oxford University Press, 1990).

Oxford Advanced Learner's Dictionary of Current English (A. S. Hornby, Oxford University Press, 1974).

Özkirimli, U. and Sofos, S. (2008). Tormented by History. Nationalism in Greece and Turkey. London: Hurst \& Company.

Panagiotopoulos, P. (1994). The representation of suffering in the narration of two extreme experiences: Giorgis Pikros, Makronissos Chronicle, Primo Levi, Si c'est un home. Dokimes, 2: 13-32.

Panagiotopoulos, P. and Vamvakas, V. (2014). Acrobats on a Rope. Greek Society between European Demands and Archaic Cultural Reflexes. In Temel, B. (Ed.) The Great Catalyst. European Union Project and Lessons from Greece and Turkey. (113-134). Plymouth: Lexington Books.

Pantazopoulos, A. (2001). For the People and the Nation. The Andreas Papandreou Moment 1965-1989. Athens: Polis editions.

Papacharissi, Z. (2015). Affective Publics: Sentiment, Technology, and Politics. New York: Oxford University Press.

Papacosma, V. S. (1988). Politics and Culture in Greece. Ann Arbor: University of Michigan Press.

Papandreou, A. (1969). Democracy at Gunpoint: The Greek Front, New York: Doubleday. Pappas T. S. (2016). Modern Populism: Research Advances, Conceptual and Methodological Pitfalls, and the Minimal Definition. Oxford Research Encyclopedia of Politics. DOI: 10.1093/acrefore/9780190228637.013.17.

Petersen, R. D. (2002). Understanding Ethnic Violence: Fear, Hatred, and Resentment in Twentieth-Century Eastern Europe. Cambridge: Cambridge University Press.

Peterson, J. B. (2018). 12 Rules for Life. An Antidote to Chaos. London: Penguin Random House.

Petropoulos, E. (2000). Songs of The Greek Underworld: The Rebetika Tradition. London: Saqe Books.

Petropoulos, J. A. (1968). Politics and Statecraft in the Kingdom of Greece, 1833-1843. Princeton: Princeton University Press.

Pirc, T. (2018). The collective of Ressentiment: Psychopolitics, Mediocrity, and Morality. In Pirc, T. (Ed.) Participation, Culture and Democracy. Perspective on Public Engagement and Social Communication. (111-132). Newcastle: Cambridge Scholars Publishing. 
Planalp, S., Hafen, S., and Adkins, A. D. (2000). Messages of Shame and Guilt. In Roloff, M. E. (Ed.) Communication Yearbook 23. (1-65). London: Sage Publications.

Portman, J. (2000). When Bad Things Happen to Other People. London: Routledge.

Posner, R. A. (2004). Catastrophe: Risk and Response. Oxford: Oxford University Press.

Postman, N. (1985). Amusing Ourselves to Death. Public Discourse in the Age of Show Business. London: Penguin Books.

Posłuszna, E. and Posłuszny, J. (2015). The Trouble with Ressentiment. Ruch Filozoficzny, 71(4): 87-104. DOI: http://dx.doi.org/10.12775/RF.2015.006.

Potamitis, N. Y. (2008). Antagonism and Genre. Resistance, the Costume Romance and the Ghost of Greek Communism. In Carpentier, N. and Spinoy E. (Eds) Discourse Theory and Cultural Analysis Media, Arts and Literature. (119-139). NJ: Hampton Press.

Protevi, J. (2014). Political Emotion. In von Scheve, C. and Salmela, M. (Eds) Collective Emotions. Perspectives from Psychology, Philosophy, and Sociology. (326-340). Oxford: Oxford University Press.

Protevi, J. (2009). Political Affect. Connecting the Social and the Somatic. Minneapolis: University of Minnesota Press.

Pupavac, V. (2007). Therapeutic Governance: The Politics of Psychosocial Intervention and Trauma Risk Management www.odi.org.uk/hpg/confpapers/pupavac.

Rawls, J. (1971/1991). A Theory of Justice. Oxford: Oxford University Press.

Rayburn J. D. II. (1996). Uses and Gratifications. In Salwen, M. and Stacks, D. (Eds) An Integrated Approach to Communication Theory and Research. (145-163). New Jersey: Lawrence Erlbaum Associates.

Reimer, D. J. (2007). Stories of Forgiveness: Narrative Ethics and the Old Testament. In Rezetko, R., Lim, T. H., and Auker, W. B. (Eds) Reflection and Refraction. Studies in Biblical Historiography in Honour of A. Graeme Auld. (Vol. 113) (359-378). Leiden and Boston: Brill. Supplements to VT.

Reinert, H. and Reinert, E. S. (2006). Creative Destruction in Economics: Nietzsche, Sombart, Schumpeter. In Backhaus, J. R. and Drechsler, W. (Eds) Friedrich Nietzsche 1844-2000: Economy and Society. (55-85). Boston: Springer/Kluwer.

Renan, E. (1995). What is a nation? In Dahbour, O. and Ishay, M. R. (Eds) The Nationalism Reader. (143-155). New Jersey: Humanities Press.

Revault d' Allonnnes, M. (2008). L' Homme Compassionnel. Paris: Éditions du Seuil.

Richards, B. (2019). The Psychology of Politics. New York: Routledge.

Richards, B. (2018). What Holds Us Together. Popular Culture and Social Cohesion. London: Karnac.

Richards, B. (2010). News and the emotional public sphere. In Allan, S. (Ed.) The Routledge Companion to News and Journalism. (301-311). London, UK: Routledge.

Richards, B. (2007). Emotional Governance: Politics, Media and Terror. Basingstoke: Palgrave Macmillan.

Richter, H. (1997). The British Intervention in Greece. From Varkiza to the Civil War. February 1945-August 1946. Athens: Estia.

Robinson, E. (2016). Radical Nostalgia, Progressive Patriotism and Labour's 'English Problem'. Political Studies Review, 14(3): 378-387.

Rooduijn, M. (2014). The Nucleus of Populism: In Search of the Lowest Common Denominator. Government and Opposition, 49(4): 572-598. DOI: 10.1017/gov.2013.30.

Rosas, O. V. and Serrano-Puche, J. (2018). News Media and the Emotional Public Sphere. International Journal of Communication, 12: 2031-2039. 
Rico, G., Guinjoan, M., and Anduiza, E. (2017). The Emotional Underpinnings of Populism: How Anger and Fear Affect Populist Attitudes. Swiss Political Science Review. DOI: $10.1111 /$ spsr.12261.

Ricoeur, P. (2004a). Le Mal: Undéfit à la Théologie (3rd edition). Geneva: Laboret Fides. Ricoeur, P. (2004b). Memory, History, Forgetting. Chicago: University of Chicago Press.

Riggs, F. (1964). Administration in Developing Countries: The Theory of Prismatic Society. Boston: Houghton Mifflin Company.

Robin, C. (2004). Fear. The History of a Political Idea. Oxford: Oxford University Press.

Robins, K. (2001). Seeing the world from a safe distance. Science as Culture, 10(4): 531-539.

Rorty, R. (1989). Contingency, Irony, and Solidarity. Cambridge: Cambridge University Press.

Rosen, J. (2002). September 11 in the Mind of American Journalism. In Zelizer, B. and Allan, S. (Eds) Journalism after September 11. (27-35). London: Routledge.

Rosenau, P. M. (1992). Post-Modernism and the Social Sciences. Insights, Inroads, and Intrusions. Princeton/New Jersey: Princeton University Press.

Rosenwein, B. (2001). Writing Without Fear About Early Medieval Emotions. Early Medieval Europe, 10(2): 229-234.

Roth, M. S. (2012). Memory, Trauma, and History. Essays on Living with the Past. New York: Columbia University Press.

Roudometof, V. and Christou, M. (2013). 1974 and Greek Cypriot Identity: The Division of Cyprus as Cultural Trauma. In Eyerman, R., Alexander, J. C., and Breese, E. (Eds) Narrating Trauma. On the Impact of Collective Suffering. (163-187). Boulder \& London: Paradigm Publications.

Rousso, H. (1991). The Vichy Syndrome. History and Memory in France since 1944. Cambridge: Harvard University Press.

Rovira-Kaltwasser, C., Taggart, P., Espejo, P. O., and Ostiguy, P. (2017). Populism. An Over view of the Concept and the State of the Art. In Rovira-Kaltwasser, C., Taggart, P., Espejo, P. O., and Ostiguy, P. (Eds) The Oxford Handbook of Populism. (1-24). Oxford: Oxford University Press.

Sadler, G. (2008). Forgiveness, anger, and virtue in an Aristotelean perspective. Proceedings of the American Catholic Philosophical Association, 82: 229-247.

Salmela, M. and von Scheve, C. (2018). Emotional Dynamics of Right- and Left-Wing Political Populism. Humanity \& Society, 42(4): 434-454.

Salmela, M. and von Scheve C. (2017). Emotional roots of right-wing political populism. Social Science Information, 1-29. DOI: https://doi.org/10.1177/0539018417734419.

Sambanis, N. (2002). A Review of Recent Advances and Future Directions in the Literature on Civil War. Defense and Peace Economics, 13(2): 215-243.

Sarat, I. A. and Hussain, N. (2007). Forgiveness, Mercy, and Clemency. Stanford: Stanford University Press.

Sayer, A. (2005). The Moral Significance of Class. Cambridge: Cambridge University Press.

Scheff, T. J. (2000). Bloody Revenge: Emotions, Nationalism and War. Bloomington, IN: iUniverse.com, Inc.

Scheff, T. J. (1997a). Emotions, the Social Bond, and Human Reality: Part/Whole Analysis. Cambridge: Cambridge University Press.

Scheff, T. J. (1997b). Alienation, Nationalism, and Inter-ethnic Conflict. www.soc.ucsb. edu/faculty/scheff/main.php?id=5.html.

Scheff, T. J. (1994a). Emotions and Identity: A Theory of Ethnic Nationalism. In Calhoun, C. (Ed.) Social Theory and the Politics of Identity. (277-303). Oxford: Blackwell Publishers 
Scheff, T. J. (1994b). Bloody Revenge. Emotions, Nationalism and War. Boulder: Westview Press.

Scheler, M. (1980). Problems of a Sociology of Knowledge. London: Routledge and Kegan Paul.

Scheler, M. (1961). Ressentiment. Glencoe: Free Press.

Scheler, M. (1954). The Nature of Sympathy. London: Routledge \& Kegan Paul Ltd.

Scherer, K. R. (2009). The dynamic architecture of emotion: Evidence for the component process model. Cognition \& Emotion, 23(7): 1307-1351.

Scherer, K. R. (2001). Appraisal considered as a process of multi-level sequential checking. In Scherer, K. R., Schorr, A., and Johnstone, T. (Eds) Appraisal Processes in Emotion: Theory, Methods, Research. (92-120). New York: Oxford University Press.

Scherke, K. (2018). Nostalgie und Politik. Eine emotionssoziologische Perspektive. Zeitschrift für Politik, 65(1): 81-96.

Scherke, K. (2015). Emotion: History of the Concept. In Wright, J. D. (Ed.) International Encyclopedia of the Social \& Behavioral Sciences. (472-476). Vol. 7. Oxford: Elsevier (2nd edition).

Schieman, S. (2006). Anger. In Stets, J. and Turner, J. (Eds) Handbook of the Sociology of Emotions. (493-515). New York: Springer.

Schmitt, C. and Clark, C. (2006). Sympathy. In Stets, I. E. and Turner, J. H. (Eds), Handbook of the Sociology of Emotions. (467-492). New York: Springer.

Schoeck, H. (1969). Envy: A Theory of Social Behavior, (translated by Glenny and Ross). New York: Harcourt, Brace.

Schramm, H. and Wirth, W. (2008). A case for an integrative view on affect regulation through media usage. Communications, 33: 27-46. DOI: 10.1515/COMMUN.2008.002.

Schreiber, D. (2007). Political Cognition: Are We All Political Sophisticates? In Neuman, R. et al. (Eds) The Affect Effect. Dynamics of Emotion in Political Thinking and Behavior. (46-70). Chicago: The University of Chicago Press.

Schudson, M. (1997). The Sociology of News Production. In Berkowitz, D. (Ed.) Social Meanings of New; A Text-Reader. (7-22). London: Sage Publications.

Schutz, A. (1978). Phenomenology and the Social Sciences. In Luckmann, T. (Ed.) Phenomenology and Sociology. Selected Readings. (119-141). Middlesex: Penguin Books.

Schwab, F. and Schwender, C. (2011). The descent of emotions in media. Darwinian perspectives. In Döveling, K., von Scheve, C., and Konijn, E. A. (Eds) The Routledge Handbook of Emotions and Mass Media. (16-36). London: Routledge.

Schwartz, B. (1978). Vengeance and forgiveness: The uses of beneficence in social control. School Review, 86: 655-668.

Scott, A. (2000). Risk Society or Angst Society? Two Views of Risk, Consciousness and Community. In Adam, B. Beck, U., and Loon, J. V. (Eds) The Risk Society and Beyond. Critical Issues for Social Theory. (33-46). London: Sage Publications.

Scott, M. (2014). The mediation of distant suffering: An empirical contribution beyond television news texts. Media, Culture \& Society, 36(1): 3-19.

Scouras, F., Chatjidemos, A., Kaloutsis, A., and Papademetriou, G. (1947). The Psychopathology of Hunger, Fear and Anxiety. A Medical Chronicle of Occupation. Athens: Exandas.

Scruton, R. (2006). A Political Philosophy. London/New York: Continuum.

Searle J. R. (1995). The Construction of Social Reality. London: Allen Lane, The Penguin Press.

Sears, D. (2001). The Role of Affect in Symbolic Politics. In Kuklinski, J. H. (Ed.) Citizens and Politics. (14-40). Cambridge: Cambridge University Press. 
Sears, D. O., Huddy, L., and Jervis, R. (Eds) (2003). Oxford Handbook of Political Psychology. Oxford: Oxford University Press.

Sennett, R. (1977). The Fall of Public Man. London: Faber and Faber.

Sennett, R. and Cobb, J. (1972). The Hidden Injuries of Class. New York: W.W. Norton \& Company.

Sewell, W. H. Jr. (1996). Historical events as transformations of structures: Inventing revolution at the Bastille. Theory and Society 25: 841-881.

Shils, E. (1956). The Torment of Secrecy: the Background and Consequences of American Security Policies. London: Heinemann.

Shoah Resource Center (1998). An Interview with Professor Jacques Derrida. January 8, 1998, Jerusalem, Interviewer: Dr. Michal Ben-Naftali (translated from French by Dr. Moshe Ron). The International School for Holocaust Studies. (www.yadvashem.org).

Shriver, D. W. (1998). An Ethic for Enemies: Forgiveness in Politics. Oxford: Oxford University Press.

Silverstone, R. (2007). Media and Morality. On the Rise of Mediapolis. London: Polity Press.

Skillington, T. (2015). Violence, memory, time: Towards a cosmopolitan model of learning from atrocity. In Marinopoulou, A. (Ed.) Cosmopolitan Modernity. (177-201). Oxford: Peter Lang.

Slaby, J. and Bens, J. (2019). Political Affect. In Slaby, J. and von Scheve, C. (Eds) Affective Societies. Key Concepts. (340-351). London and New York: Routledge.

Slaby, J. and Mühlhoff, R. (2019). Affect. In Slaby, J. and von Scheve, C. (Eds) Affective Societies. Key Concepts. (27-41). London and New York: Routledge.

Slaby, J. and von Scheve, C. (Eds) (2019a). Affective Societies. Key Concepts. London and New York: Routledge.

Slaby, J. and von Scheve, C. (2019b). Introduction. Affective Societies - Key Concepts. In Slaby, J. and von Scheve, C. (Eds) Affective Societies. Key Concepts. (1-24). London and New York: Routledge.

Sloterdijk, P. (2010). Rage and Time. A Psychopolitical Investigation (translated by Mario Wenning). New York: Columbia University Press.

Sloterdijk, P. (2006). Zorn und Zeit: Politisch-psychologischer Versuch. Frankfurt am Main: Suhrkamp Verlag.

Sloterdijk, P. (1988). Critique of Cynical Reason. London: Verso.

Smelser, N. (2004). Psychological trauma and cultural trauma. In Alexander J. C. et al. (Eds) Cultural Trauma and Collective Identity. (31-59). Berkeley: University of California Press.

Smith, A. (1976). The Theory of Moral Sentiments. Indianapolis: Liberty Press. [First published in 1759].

Smith, A. (1986). The Ethnic Origins of Nations. London: Blackwell.

Smith, A. (1971). Theories of Nationalism. Duckworth: London.

Smith, D. (2006). Globalization. The Hidden Agenda. Cambridge: Polity.

Snyder L. (1954). The Meaning of Nationalism. Connecticut: Greenwood Press (2nd reprint 1972).

Sokolon, M. (2006). Political Emotions. Aristotle and the Symphony of Reason and Emotion. Illinois: Northern Illinois University Press.

Soler, C. (2016). Lacanian Affects: The Function of Affect in Lacan's Work (translated by B. Fink). New York: Routledge.

Solomon, R. (1994). One Hundred Years of Ressentiment. Nietzsche's Genealogy of Morals. In Schacht, R. (Ed.) Nietzsche, Genealogy, Morality. (95-126). Berkeley: University of California Press. 
Sombart, W. (1998). The Quintessence of Capitalism: A Study of the History and Psychology of the Modern Business Man. London: Routledge.

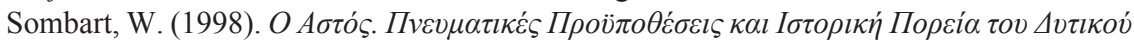

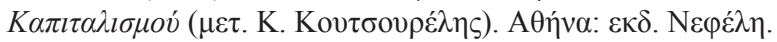

Sontag, S. (2003). Regarding the Pain of Others. New York: Farrar, Strauss and Giroux.

Sotiropoulos, P. D. (2019). Historical Patterns of Greek Exoticism (Nineteenth-Twentieth Century). In Panagiotopoulos, P. and Sotiropoulos, P. D. (Eds) Political and Cultural Aspects of Greek Exoticism. (11-25). Cham: Palgrave/Macmillan.

Spasić I. (2013). The Trauma of Kosovo in Serbian National Narratives. In Eyerman, R. Alexander, J. C. and Breese, E. (Eds) Narrating Trauma. On the Impact of Collective Suffering. (81-105). Boulder \& London: Paradigm Publications.

Stavrakakis, Y. (Ed.) (2019). Routledge Handbook of Psychoanalytic Political Theory. London: Routledge.

Stavrakakis, Y. (2017a). Populism and Hegemony. In Kaltwasser, C. R., Taggart, P., Espejo, P. O., and Ostiguy, P. (Eds) The Oxford Handbook of Populism. (535-553). Oxford: Oxford University Press.

Stavrakakis, Y. (2017b). Discourse theory in populism research. Three challenges and a dilemma. Journal of Language and Politics 1-12. DOI: 10.1075/jlp.17025.sta.

Stavrakakis, Y. (1999). Lacan and the Political. London: Routledge.

Stavrakakis, Y. Andreadis, I., and Katsambekis, G. (2016). A new populism index at work: Identifying populist candidates and parties in the contemporary Greek context. European Politics and Society. DOI: 10.1080.23745118.2016.1261434.

Stavrou, G. T. (1995). The Orthodox Church and Political Culture in Modern Greece. In Constas, D. and Stavrou, G. T. (Eds) Greece Prepares for the Twenty-first Century. (35-56). Baltimore and London: The John Hopkins University Press.

Stern, B. B. (1992). Historical and personal nostalgia in advertising text: The fin de siècle effect, Journal of Advertising, 21: 11-22.

Stewart, A. (1969). The Social Roots. In Ionescu, G. and Gellner, E. (Eds) Populism. Its Meanings and National Characteristics. (180-196). Hertfordshire: The Garden City Press.

Stivers, R. (1994). The Culture of Cynicism. American Morality in Decline. Oxford: Blackwell.

Stevenson, N. (1997). Media, Ethics and Morality. In: McGuigan, J. (Ed.) Cultural Methodologies. (62-86). London: Sage Publications Ltd.

Strawson, P. F. (1974). Freedom and Resentment and Other Essays. London: Methuen \& Co.

Sturzo, D. L. (1946). Nationalism and Internationalism. New York: Roy.

Sugar, P. F. (1969). External and Domestic Roots of Eastern European Nationalism. In Sugar, P. F. and Lederer, I. (Eds) Nationalism in Eastern Europe. (3-54). Seattle and London: University of Washington Press.

Sullivan, B. G. (2014a). Collective pride, happiness, and celebratory emotions: aggregative, network, and cultural models. In von Scheve, Ch. and Salmela, M. (Eds) Collective Emotions. Perspectives from Psychology, Philosophy, and Sociology. (266-280). Oxford: Oxford University Press.

Sullivan, B. G. (Ed.) (2014b). Understanding Collective Pride and Group Identity. New Directions in Emotion Theory, Research and Practice. London and New York: Routledge.

Sznaider, N. (1998). The Sociology of Compassion: A Study in the Sociology of Morals. Cultural Values, 2(1): 117-39. 
Sztompka, P. (2004). The Trauma of Social Change. A Case of Postcommunist Societies. In Alexander J. C., Eyerman, R., Giesen, B., Smelser, J. N., and Sztompka, P. (Eds) Cultural Trauma and Collective Identity. (155-195). Berkeley: University of California Press.

Taggart, P. (2000). Populism. Buckingham. Open University Press.

Taguieff, P.-A. (2007). L' Illusion Populiste. De l'Archaïque au Mediatique. Paris: Flammarion.

Tarchi, M. (2016). Populism: ideology, political style, mentality? Czech Journal of Political Science, 23: 95-109.

Tavuchis, N. (1991). Mea Culpa: A Sociology of Apology and Reconciliation. Stanford, CA: Stanford University Press.

Taylor, C. (1992). Multiculturalism and 'the Politics of Recognition'. An Essay. Princeton, NJ: Princeton University Press.

Taylor, G. (2010). The New Political Sociology. Power, Ideology and Identity in an Age of Complexity. Basingstoke: Palgrave Macmillan.

Tenenboim-Weinblatt, K. (2008). 'We will get through this together': Journalism, trauma and the Israeli disengagement from the Gaza Strip. Media, Culture and Society, 30(4): 495-513.

TenHouten, W. D. (2018). From Ressentiment to Resentment as a Tertiary Emotion. Review of European Studies, 10(4): 1-16.

TenHouten, W. D. (2007). A General Theory of Emotions and Social Life. London \& New York: Routledge.

Tester, K. (2001). Compassion, Morality and the Media. Buckingham: Open University Press.

Tester, K. (1997). Moral Culture. London, Thousand Oaks, California: Sage.

The Concise Oxford Dictionary of Current English (8th edition by R. E. Allen, Clarendon Press, Oxford, 1990).

Thoits, P. A. (1989). The Sociology of Emotions. Annual Review of Sociology, 15: 317-342.

Thompson, B. J. (1995). The Media and Modernity. A Social Theory of the Media. Cambridge: Polity Press.

Thompson, S. and Hoggett, P. (Eds) (2012). Politics and the Emotions. The Affective Turn in Contemporary Political Studies. New York and London: Continuum International Publishing Group.

Ting-Toomey, S. (1994). Managing intercultural conflicts effectively. In Samovar, L. and Porter, R. (Eds) Intercultural Communication: A Reader. (360-372). Wadsworth, Belmont, CA.

Tivey, L. (1981) (Ed.) The Nation-State. The Formation of Modern Politics. Oxford: Martin Robertson.

Tocqueville, A. de (1969). Democracy in America. New York: Anchor Books.

Todorov, Tzv. (2010). The Fear of Barbarians. Beyond the Clash of Civilizations. Cambridge: Polity Press.

Todorov, Tzv. (1995). Les Abus de la Mémoire. Paris: Arléa.

Tollefsen, D. (2006). The rationality of collective guilt. Midwest Studies in Philosophy. 30: 222-239.

Tomelleri, S. (2013). The sociology of resentment. In Fantini, B., Moruno, D. M. and Moscoso, J. (Eds) On Resentment: Past and Present. (259-276). Newcastle: Cambridge Scholars Publishing.

Trevor-Roper, H. (1962). Jewish and other Nationalisms Fifth Herbert Samuel Lecture, 2 Oct. 1961. London: Weidenfeld and Nicolson. 
Triandafyllidou, A., Gropas, R., and Kouki, H. (2013). Introduction: Is Greece a Modern European Country? In Triandafyllidou, A., Gropas, R., and Kouki, H. (Eds) The Greek Crisis and European Modernity. (1-24). Basingstoke: Palgrave Macmillan.

Tsoukalas, C. (1969). The Greek Tragedy. London: Harmondsworth, Penguin.

Turner, J. H. (1975). Marx and Simmel Revisited: Reassessing the Foundations of Conflict. Social Forces, 53(4): 618-627.

Turner, J. H. and Stets, J. E. (2005). The Sociology of Emotions. Cambridge: Cambridge University Press.

Ure, M. (2015). Resentment/Ressentiment. Constellations: An International Journal of Critical and Democratic Theory, 22(4): 599-613.

Van Stekelenburg, J. and Klandermans, B. (2011). The Social Psychology of Protest. Sociopedia.isa. Sage Publications.

Van Troost, D., Van Stekelenburg, J., and Klandermans, B. (2013). Emotions of Protest. In N. Demertzis (Ed.) Emotions in Politics: The Affect Dimension in Political Tension. (186-203). London: Palgrave Macmillan.

van Tuinen, S. (2020). The resentment-ressentiment complex: a critique of liberal discourse. Global Discourse: An Interdisciplinary Journal of Current Affairs. DOI: https:// doi.org/10.1332/204378920X15828100918561.

Vaneigem, R. (2012). The Revolution of Everyday Life. Oakland: PM Press.

Vattimo, G. (1992). The Transparent Society. Cambridge: Polity Press.

Velleman, J. D. (2003). Don't Worry, Feel Guilty. In A. Hatzimoysis (Ed.) Philosophy and the Emotions. (235-248). Cambridge: Cambridge University Press.

Vogler, C. (2000). Social identity and emotion: the meeting of psychoanalysis and sociology. The Sociological Review, 48(1): 19-42. https://doi.org/10.1111/1467-954X.00201.

Voglis, P. (2008). Memories of the 1940s as a topic of historical analysis: methodological proposals. In Bouschoten P. B., Vervenioti, T., Voutira, E., Dalkavoukis, V., and Bada, K. (Eds) Memories and Forgetting of the Greek Civil War. (61-80). Salonica: Epikentron.

Voglis, P. (2002). Becoming a Subject. Political Prisoners during the Greek Civil War. $\mathrm{PhD}$. European University Institute, Florence.

Voglis, P. (2000). Between Negation and Self-Negation: Political Prisoners in Greece, 1945-1950. In Mazower, M. (Ed.) After the War Was Over. Reconstructing the Family, Nation, and State in Greece, 1943-1960. (73-90). Princeton and Oxford: Princeton University Press.

Volkan, V. (2005). Large-group identity and chosen trauma. Psychoanalysis Downunder, 6. www.psychoanalysisdownunder.com.au/.

Volkan, V. (2004). Blind Trust. Large Groups and Their Leaders in Times of Crisis and Terror. Charlottesville, Virginia: Pitchstone Publishing.

Volkan, V. (2001). Transgenerational transmissions and chosen traumas: An aspect of large-group identity. Group Analysis, 34(1): 79-97.

Von Martin, A. (2016). Soziologie der Renaissance und Weitere Schriften. Klassiker der Sozialwissenschaften. Wiesbaden: Springer Fachmedien. DOI: 10.1007/978-3-65810449-8_3.

Von Martin, A. (1944). Sociology of the Renaissance (translated by W. L. Luetkens). London: Kegan Paul.

von Scheve, C. (2013). Emotion and Social Structures. The Affective Foundations of Social Order. London and New York: Routledge.

von Scheve, C. and Salmela, M. (Eds) (2014). Collective Emotions. Perspectives from Psychology, Philosophy, and Sociology. Oxford: Oxford University Press. 
von Scheve, C. and Slaby, J. (2019). Emotion, emotion concept. In Slaby, J. and von Scheve, C. (Eds) Affective Societies. Key Concepts. (42-51). London and New York: Routledge.

von Scheve, C. and von Luede, R. (2005). Emotion and Social Structures: Towards an Interdisciplinary Approach. Journal for the Theory of Social Behavior, 35(3): 303-328.

Vorderer, P. A. and Hartmann, T. (2009). Entertainment and Enjoyment as Media Effects. In Bryant, J. and Oliver, M. B. (Eds) Media Effects. Advances in Theory and Research. (3rd edition) (pp. 532-550). New York: Taylor \& Francis.

Wade, G. N., Worthington, L. E., and Meyer, E. J. (2005). But Do They Work? A MetaAnalysis of Group Interventions to Promote Forgiveness. In Worthington, L. E. (Ed.) Handbook of Forgiveness. (423-439). New York: Routledge.

Wahl-Jorgensen, K. (2019). Emotions, Media and Politics. Cambridge: Polity Press.

Walicki, A. (1969). Russia. In Ionescu, G. and Gellner, E. (Eds). Populism. Its Meanings and National Characteristics. (62-96). Hertfordshire: The Garden City Press.

Wallerstein, E. (2000). The Essential Wallerstein. New York: The New Press.

Walzer, M. (1994). Thick and Thin. Moral Argument at Home and Abroad. Notre Dame: University of Notre Dame Press.

Ward, L. (2012). A new century of trauma? Alluvium, 1(7). http://dx.doi.org/10.7766/ alluvium.v1.7.03.

Warren, M. (Ed.) (1999). Democracy \& Trust. Cambridge: Cambridge University Press.

Wastell, C. (2005). Understanding Trauma and Emotion, Berkshire: Open University Press.

Weber, A-K. (2018). The Pitfalls of 'Love and Kindness': On the Challenges to Compassion/ Pity as a Political Emotion. Politics and Governance, 6(4): 53-61.

Weber, M. (1978a), Economy and Society (Vol. I). Berkeley: University of California Press.

Weber, M. (1978b). Economy and Society (Vol. II). Berkeley: University of California Press.

Weil, S. (1962). Selected Essays, 1934-1943: Historical, Political, and Moral Writings (chosen and translated by Richard Rees). Oregon: Wipf and Stock Publishers.

Wenning, M. (2009). The Return of Rage. Parrhesia, 8: 89-99.

Wetherell, M. (2012). Affect and Emotion. A New Social Science Understanding. Los Angeles: Sage.

Williams, J. S. (2009). A 'Neurosociology' of Emotion? Progress, Problems and Prospects. In Hopkins, D., Kleres, J., Flam, H., and Kuzmics, H. (Eds) Theorizing Emotions: Sociological Explorations and Applications. (315-337). Berlin: Campus.

Williams, R. (1987). Culture and Society. Coleridge to Orwell. London: The Hogarth Press. Williams, R. (1980). Problems in Materialism and Culture. London: Verso.

Williams, R. (1978). Marxism and Literature. Oxford: Oxford University Press.

Williams, R. (1965). The Long Revolution. Middlesex: Pelican Books.

Williams, W. D. (1952). Nietzsche and the French. A Study of the Influence of Nietzsche's French Reading on his Thought and Writing. Oxford: Basil Blackwell.

Wilson, T. (1993). Watching Television. Hermeneutics, Reception and Popular Culture. Cambridge: Polity Press.

Wimberly, C. (2018). Trump, Propaganda, and the Politics of Ressentiment. The Journal of Speculative Philosophy, 32(1): 179-195. DOI: 10.5325/jspecphil.32.1.0179.

Wirth, W. and Schramm, H. (2005). Media and Emotions. Communication Research Trends, 24: 3-39. 
Worthington, L. E. and Cowden R.G. (2017). The psychology of forgiveness and its importance in South Africa. South African Journal of Psychology, 47: 292-304. DOI: $10.1177 / 0081246316685074$.

Woshinsky, O. H. (1995). Culture and Politics. An Introduction in Mass and Elite Political Behavior. New Jersey: Prentice Hall.

Wouters, C. (2007). Informalization: Manners and Emotions Since 1890. London: Sage.

Wyschogrod, E. (1998). An Ethics of Remembering: History, Heterology, and the Nameless Others. Chicago \& London: University of Chicago Press.

Xydis, S. (1980). Modern Greek Nationalism. In Sugar, P. and Lederer, I. (Ed.) Nationalism in Eastern Europe. (207-258). Washington D.C.: University of Washington Press.

Yankelovich, D. (2009). The New Pragmatism: Coping with America's Overwhelming Problems. Bulletin of the American Academy (Spring): 25-30.

Yankelovich, D. (1975). The Status of Ressentiment in America. Social Research, 42(4): 760-777.

Yates, C. (2019). Affect and Emotion. In Stavrakakis, Y. (Ed.) Routledge Handbook of Psychoanalytic Political Theory. (162-173). London: Routledge.

Yates, C. (2015). The Play of Political Culture, Emotion and Identity. Basingstoke: Palgrave Macmillan.

Zelizer, B. (2002). Finding aids to the past: bearing personal witness to traumatic public events. Media, Culture and Society, 24(5): 697-714.

Zelizer, B. and Allan S. (Eds) (2002). Journalism after September 11. London: Routledge.

Zillmann, D. (2011). Mechanisms of emotional reactivity to media entertainments. In Döveling, K., von Scheve, C., and Konijn, E. A. (Eds) The Routledge Handbook of Emotions and Mass Media. (101-115). London: Routledge.

Žižek, S. (2008). Violence. Six Sideways Reflections. New York: Picador.

Žižek, S. (1997). The Plague of Fantasies. London: Verso.

Žižek, S. (1996). The Indivisible Remainder. London: Verso.

Žižek, S. (1989). The Sublime Object of Ideology. London: Verso. 